\begin{tabular}{|c|c|c|c|c|c|c|}
\hline \multirow{4}{*}{ Impact Factor: } & ISRA (India) & $=3.117$ & SIS (USA) & $=0.912$ & ICV (Poland) & $=6.630$ \\
\hline & ISI (Dubai, UAE & $=0.829$ & РИНЦ (Russia) & $=0.156$ & PIF (India) & $=1.940$ \\
\hline & GIF (Australia) & $=0.564$ & ESJI (KZ) & $=8.716$ & IBI (India) & $=4.260$ \\
\hline & JIF & $=1.500$ & SJIF (Morocco) & $=5.667$ & OAJI (USA) & $=0.350$ \\
\hline
\end{tabular}

\begin{tabular}{|c|c|}
\hline $\begin{array}{l}\text { SOI: } \underline{1.1 / \mathrm{T}} \\
\text { International Sc } \\
\text { Theoretical } \boldsymbol{\&}\end{array}$ & $\begin{array}{l}\text { AS DOI: } 10.15863 / \text { TAS } \\
\text { ientific Journal }\end{array}$ \\
\hline p-ISSN: 2308-4944 (print) & e-ISSN: 2409-0085 (online) \\
\hline Year: 2019 Issue: 03 & Volume: 71 \\
\hline Published: 19.03 .2019 & http://T-Science.org \\
\hline
\end{tabular}

UDC 685. 74 519. 37.

SECTION: Technical sciences
QR - Issue

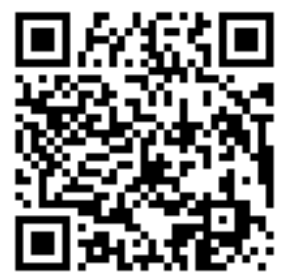

QR - Article

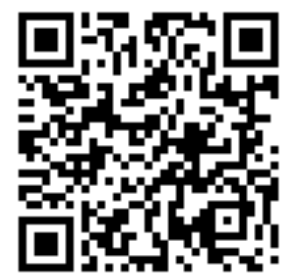

Artur Alexandrovich Blagorodov bachelor, Department of "Design, technology, and design" Institute of service sector and entrepreneurship (branch) of

DSTU in Shakhty, Rostov region bordux1995@icloud.com

Dmitry Olegovich Bordukh bachelor, Department of "Design, technology, and design" Institute of service sector and entrepreneurship (branch) of DSTU in Shakhty, Rostov region bordux1995@icloud.com

Angelina Vladimirovna Kopylova bachelor, Department of "Design, technology, and design" Institute of service sector and entrepreneurship (branch) of

DSTU in Shakhty, Rostov region prohorov@sssu.ru

Daria Sergeevna Smolina bachelor, Department of "Design, technology, and design" Institute of service sector and entrepreneurship (branch) of DSTU in Shakhty, Rostov region prohorov@sssu.ru

Vladimir Timofeevich Prokhorov Doctor of technical sciences, professor, Professor the department "Designing, technology and design", ISOP (f) DGTU, Shakhty prohorov@sssu.ru

Yuri Dmitrievich Mishin Professor, candidate of philosophy, Department of Philosophy and Culturology "Siberian state University of railway communication" Novosibirsk vinichenkoan@stu.ru

\title{
MANAGEMENT FEATURES QUALITY OF DIGITAL DEFECT-FREE PRODUCTION OF IMPORT-SUBSTITUTING PRODUCTS FOR CONSUMERS IN THE REGIONS OF SFD AND SCFO (1 MESSAGE)
}

Abstract: in the message 1 the possibilities of production of competitive and demanded production which are possible only in the presence of the heads professionally prepared and politically responsible for results of the activity are considered. The authors reasonably believe that the political responsibility of the heads of light industry enterprises is the highest measure of expression of their professionalism. But at the same time, I would like to note that their failure to fulfill political promises and statements is evidence of either their inability to engage in economic policy, or the use of political governance is carried out in their personal interests, alien to the interests of society, provoking the impoverishment of the people, characterizing the immorality of leaders, which, of course, is 


\begin{tabular}{|c|c|c|c|c|c|c|}
\hline \multirow{4}{*}{ Impact Factor: } & ISRA (India) & $=3.117$ & SIS (USA) & $=0.912$ & ICV (Poland) & $=6.630$ \\
\hline & ISI (Dubai, UAE & $=\mathbf{0 . 8 2 9}$ & РИНЦ (Russia & $=0.156$ & PIF (India) & $=1.940$ \\
\hline & GIF (Australia) & $=0.564$ & ESJI (KZ) & $=8.716$ & IBI (India) & $=4.260$ \\
\hline & JIF & $=1.500$ & SJIF (Morocco & $=5.667$ & OAJI (USA) & $=0.350$ \\
\hline
\end{tabular}

unacceptable. And it is clear that there are no objective reasons that would justify the decline in production in light industry, so the results of the assessment of economic policy should be either useful or harmful - it should always be axiomatic. If this does not happen, then something in this very economic policy is not a professional decision, actions are harmful to society and timely adjustments are necessary. The authors recommend the market to revise the concept of the formation of its demand and import-substituting goods, taking into account their attractiveness. This concept will fully comply with the consumer's desire to satisfy their desire and desire to make a purchase, taking into account their social status, providing manufacturers with the sale of their products in full and guaranteeing businesses sustainable TPE of their activities.

Key words: QMS, certification, import substitution, demanded, conformity assessment, standardization, audit, demand, defective products, Pareto chart, quality policy and objectives, documentation, effectiveness, efficiency, responsibility.

Language: Russian

Citation: Blagorodov, A. A., Bordukh, D. O., Kopylova, A. V., Smolina, D. S., Prokhorov, V. T., \& Mishin, Y. D. (2019). Management features quality of digital defect-free production of import-substituting products for consumers in the regions of SFD and SCFO (1 message). ISJ Theoretical \& Applied Science, 03 (71), 201-247.

Soi: http://s-o-i.org/1.1/TAS-03-71-18 Doi: crossef https://dx.doi.org/10.15863/TAS.2019.03.71.18

\section{ОСОБЕННОСТИ УПРАВЛЕНИЯ КАЧЕСТВОМ ЦИФРОВОГО ПРОИЗВОДСТВА БЕЗДЕФЕКТНОЙ ИМПОРТОЗАМЕЩАЕМОЙ ПРОДУКЦИИ ДЛЯ ПОТРЕБИТЕЛЕЙ РЕГИОНОВ ЮФО И СКФО (СООБЩЕНИЕ 1)}

Аннотация: в сообщении 1 рассмотрены возможности производства конкурентоспособной $u$ востребованной продукиии, которые возможны лишь при наличии руководителей, профессионально подготовленных и политически ответственных за результаты своей деятельности. Авторы обоснованно считают, что в политической ответственности руководителей предприятий лёгкой промышленности и есть высшая мера выражения их профессионализма. Но при этом хотелось отметить, что невыполнение ими политических обещзаний и заявлений - это свидетельство либо их неспособности заниматься экономической политикой, либо использование политического управления осушествляется ими в личных интересах, чуждых интересам общества, провоцирующие обнищание народа, характеризующие безнравственность руководителей, что, конечно, недопустимо. И понятно, что нет таких объективных причин, которые оправдали бы спад производства в лёгкой промышленности, поэтому результаты оценки экономической политики должны быть либо полезными, либо вредными - это должно быть всегда аксиомой. Если этого не происходит, значит что-то в этой самой экономической политике не профессиональное решение, действия вредны для общества и необходимы своевременные коррективы. Авторы рекомендуют рынку пересмотреть концепцию по формированию его востребованными и импортозамещаемыми товарами с учетом их привлекательности. Такое понятие в полной мере будет соответствовать желанию потребителя удовлетворить свое стремление и желание совериить покупку с учетом своего сочииального статуса, обеспечивая производителям реализацию изготовленной ими продукичи в полном объеме и гарантируя предприятиям устойчивые ТЭП их деятельности.

Ключевые слова: СМК, сертификачия, импортозамещчение, востребованное, подтверждение соответствия, стандартизация, аудит, спрос, бракованная продукция, диаграмма Парето, политика и цели качества, документация, результативность, эффективность, ответственность

\section{Введение}

Характерные признаки современной мировой экономики - нестабильное производство и нестабильный спрос. Традиционно принято считать, что первое определяется вторым. Это и легло «краеугольным камнем» в фундамент экономической теории, сменившей классическую политэкономию. Согласно доминирующим экономическим представлениям XX века локомотивом развития является спрос на товары, т.е. не производство, а рынок движет экономику. Знаменитую формулу К. Маркса - одного из столпов классической политической экономики Т-Д-Т сегодня воспринимают локально, т. е. так, как она выглядит в итоговом выражении: реализация товаров зависит от количества денег, вращающихся на рынке, иначе говоря, реальной покупательной способности потребителей. От полученной продавцом выручки, в свою очередь, зависит количество и качество новой партии товаров - перспектива производства.

Рынок должен стремиться быть самодостаточным. Для нормального функционирования ему требуется максимальная свобода. Идея основоположника классической политической экономии А. Смита о необходимости свободы деятельности производителя товара в новейшей неклассической экономической теории трансформировалась в положение о свободе 


\begin{tabular}{|c|c|c|c|c|c|c|}
\hline \multirow{4}{*}{ Impact Factor: } & ISRA (India) & $=3.117$ & SIS (USA) & $=0.912$ & ICV (Poland) & $=6.630$ \\
\hline & ISI (Dubai, UAE & $=0.829$ & РИНЦ (Russia) & $=0.156$ & PIF (India) & $=1.940$ \\
\hline & GIF (Australia) & $=0.564$ & ESJI (KZ) & $=8.716$ & IBI (India) & $=4.260$ \\
\hline & JIF & $=1.500$ & SJIF (Morocco) & $=5.667$ & OAJI (USA) & $=0.350$ \\
\hline
\end{tabular}

рынка в соответствии со смещением идеологических приоритетов с производства на распределение.

А. Смит был, безусловно, прав в борьбе за свободу товаропроизводителя, свобода же рынка далеко не тождественна свободе того, кто создает реальное богатство человечества. В условиях полной свободы самодвижение рынка, начиная с масштабов региона, обречено на нестабильность. В отличие от производителей, имеющих возможность вступать в реальные кооперативные отношения и регулировать производство товаров по ассортименту, количеству, ценовой линейке и другим параметрам, продавцы, большинство среди которых перепродавцы, посредники, спекулянты, интересами производства кровно не обременены. Они давно стали продавцами профессионалами, перекупщиками. Им все равно, что продавать, главное получить хорошие и быстрые деньги. Будущее конкретного производства их абсолютно не волнует.[1]

Порочность того рынка, с которым мы имеем дело в России, заключается в следующем: вместо того, чтобы обеспечивать нормальные возможности взаимодействия покупателя с производителем (через товар и демонстрацию культуры его производства), наш рынок «разводит» основных рыночных субъектов, абсолютизируя фигуру посредника, как правило, незаинтересованного в судьбе производителя. Создается впечатление, что рынок и существует, чтобы покупатель «не парился» интересами и реальной культурой конкретного производителя, вполне достаточно бытия коммерсанта, кстати говоря, по существу, мало за что отвечающего.

«Свобода производителя» и «свобода организации коммерческой деятельности» (формально-юридические, финансовые и узко организационные инструменты контроля последней к нашей проблеме отношения не имеют, на достижение устойчивости производства, стабилизации финансовых потоков, взаимной удовлетворенности производителя и потребителя они существенно не влияют) - свободы принципиально разного порядка. Государство не должно рассматривать рынок только как источник налоговых поступлений, условие здорового образа жизни и безопасности потребления.

Рынок - звено нормального развития регионального и национального производства. Именно эта функция рынка должна быть записана первой строкой во всех документах государственной экономической политики. Саму же экономическую деятельность нужно выстроить в форме политики, нацеленной на последовательную защиту интересов производителей, причем не столько от иностранных конкурентов, сколько от земляков- чиновников и всевозможного рода приспособившихся к практике чиновников, легализовавшихся с помощью чиновников, криминальных организаций.

Фантазия неугомонного товарища Бендера ограничилась четырьмястами способами обойти статьи уголовного кодекса. Сколько подобных способов есть сейчас, вряд ли кто возьмется сосчитать. Самое же печальное заключается в том, что сегодня не нужны незаурядные творческие способности Остапа Ибрагимовича, поэтому и развелось мошенников значительно больше, чем производителей товара. Антигерой Ильфа и Петрова понимал бесперспективность быть миллионером в своей стране, бежал в Румынию и на границе потерял миллион. Для нынешних миллионеров эпизод с переходом границы и ограблением предприимчивого «сына» лейтенанта Шмидта - самое смешное место в романе.

Исторические параллели условны, однако поучительны. Повторять историю бессмысленно, из истории разумно извлекать уроки, учиться на историческом опыте, преимущественно национальном, не брезгуя и прошлой практикой других народов. Как никогда, в XXI веке актуален опыт Петра I. Петр получил прибавление «Великий», разрулив не менее сложную ситуацию, сложившуюся в стране к концу XVII столетия.

Западные границы России, для европейцев той эпохи, были рубежом, где заканчивалась цивилизация и начиналось варварство. Примерно так, за две тысячи лет до этого, греки и римляне рассматривали свои границы на севере, западе и востоке. В упадке оказалось практически все: просвещение, образование, наука, промышленность, сельское хозяйство, строительство. Рассуждения деятелей церкви, внушавших, что судьба Руси быть «третьим Римом», мало кому о чем-то говорили. Да и быть «третьим Римом», унаследовав увядшее величие Византии, представлялось не слишком заманчивой перспективой. Византия стала ординарным оплотом православия и, под влиянием церкви, избирательно относилась к научным и философским приобретениям Античности. В культуре Византии смешались идеи Аристотеля, средневековой патристики и схоластики. Понимание науки, формировавшееся в Западной Европе в XVI - XVII веках, византийские наследники решительно отвергали.

Ориентация на Византию была разумна в VIII - X столетиях. Принятие христианства и союз с могущественным покровителем способствовали интеграции славян, формированию Руси как единого государства. Тогда такой альянс был прогрессивным во всех аспектах культурного развития. 


\begin{tabular}{|c|c|c|c|c|c|c|}
\hline \multirow{4}{*}{ Impact Factor: } & ISRA (India) & $=3.117$ & SIS (USA) & $=0.912$ & ICV (Poland) & $=6.630$ \\
\hline & ISI (Dubai, UAE & $=0.829$ & РИНЦ (Russia & $=0.156$ & PIF (India) & $=1.940$ \\
\hline & GIF (Australia) & $=0.564$ & ESJI (KZ) & $=8.716$ & IBI (India) & $=4.260$ \\
\hline & JIF & $=1.500$ & SJIF (Morocco & $=5.667$ & OAJI (USA) & $=0.350$ \\
\hline
\end{tabular}

Петр принял Русь в состоянии крайней отсталости, Европа с ускорением уходила вперед, оставляя Руси азиатскую участь. Величие Петра, в отличие от современных ему политиков и духовных лидеров, проявилось не в бо́льших страданиях и молитвах, а в умении разобраться в хитросплетениях реального бытия, выделить и взять под личный контроль узловые звенья социально-экономической цепи событий прошлых и настоящих. Он правильно оценил ситуацию, акцентировав усилия на экономическом возрождении страны, по существу, принялся строить новую экономику. Экономическое строительство показало ему дефицит просвещения и образования, общей культурной составляющей. Петр развернул культурную «революцию».

Радикальные культурные новации не понравились церкви. Петр и здесь проявил характер. Он не стал никого уговаривать и ни к кому приспосабливаться. Царь возложил на себя сан патриарха.

Политика не может быть эффективной, если она будет только приспосабливаться к особенностям экономики и культуры. Политика во всем должна быть локомотивом, действовать впереди, направлять. Для политики смертельно сопровождать социально-экономическое движение.

Идеологи Запада лукавят, изображая государство посредником между производством и потреблением. Они утверждают, что задача политики обеспечить социальную справедливость распределения национального богатства, государству не следует вмешиваться в экономическое движение - оно самодостаточно. Ложь подобных лоббистских концепций становится очевидной в период кризисов. Как только начинается рецессия, спад производства, растут долги, образуется дефицит ликвидности, производители, особенно финансовые посредники, прямым ходом идут за помощью к государству и первыми ее получают.

Петр управлял страной с помощью указов. Сочинял текст указов, как правило, сам, обязательно объясняя какую именно цель имеет данный указ, как его нужно исполнять и что ожидает тех, кто не исполнит. А.С. Пушкин, изучавший архив Петра I, подметил, что указы нередко были не до конца продуманными, плодом экспромта. Великий поэт и мыслитель посвоему прав, с оговоркой, что Пушкин не был великим государем. Петр вынужден был быть оперативно жестоким. Он отвечал за судьбу Отечества. Тому, кто взял на себя такую участь, нельзя беспрестанно оглядываться на действующие законы и бояться не вписаться в их букву.
Исторические маршруты не господь бог прокладывает, они не разработаны априорно, их приходится прокладывать, осваивая новое историческое пространство. Путешественникпрофессионал не прячется за законы природы, исследуя неизведанное. И в политике следует проявлять новаторский подход, совершенствовать узаконенный порядок вещей. Законы - не абсолютны, они отражают обобщенную в юридических понятиях реальность. Политика же - искусство управлять исторически конкретной, меняющейся во времени, реальностью. Здесь важно ситуационное, проблемное мышление. Сознавая, что построить новую промышленность, активировать сельскохозяйственное производство без свободного доступа к морским перевозкам нельзя, первый российский император прибег к крайним мерам. В наше время такой необходимости - спасибо Петру I нет, что облегчает участь политиков, не снижая уровень ответственности действий, их инновационности. [2-3]

Проще всего списывать кризис традиционных для России производств на нестабильность и переходный экономический процесс. Переходный период, явно затянувшийся из-за невнятной политики, когда-то завершится. Что же касается нестабильности, то политиков ждет разочарование. По всей вероятности, цикличность кризисов, отрытую и объясненную К. Марксом, капитализм оставил в прошлом. Современные кризисы свидетельствуют не столько об особенностях динамики промышленно развитых стран, сколько о кризисе самой системы буржуазного способа производства и слабости общественной надстройки взять под контроль нарастающие негативные тенденции.

Отделение финансов от реального производства, абсолютизация свободы финансового капитала, концентрация финансовых потоков ведут развитие в тупик, обусловливают анархию, провоцируемую биржевыми спекуляциями. Нестабильность делается устойчивым, общим признаком и в пору говорить о характере нестабильности, который, как и все, изменчив, надеяться, что нестабильность не станет галопировать.

Значительная часть традиционных российских промыслов сложилась в Нечерноземье, прежде всего вокруг Москвы. География истории легкой промышленности объяснима. Был устойчивый рынок сбыта и не было дефицита в работниках, а талантом господь россиян не обделил. За двадцать лет возвращения к капитализму веками совершенствовавшиеся производства либо уже утрачены, либо доживают, потеряв надежду.[4] 


\begin{tabular}{|c|c|c|c|c|c|c|}
\hline \multirow{4}{*}{ Impact Factor: } & ISRA (India) & $=3.117$ & SIS (USA) & $=0.912$ & ICV (Poland) & $=6.630$ \\
\hline & ISI (Dubai, UAE & $=0.829$ & РИНЦ (Russia & $=0.156$ & PIF (India) & $=1.940$ \\
\hline & GIF (Australia) & $=0.564$ & ESJI (KZ) & $=8.716$ & IBI (India) & $=4.260$ \\
\hline & JIF & $=1.500$ & SJIF (Morocco & $=5.667$ & OAJI (USA) & $=0.350$ \\
\hline
\end{tabular}

Никто из политиков не «бьет в колокола», что умирают не фабрики, мастерские, цеха, рушится пласт национальной трудовой культуры. Кузнецовский фарфор, Ивановский текстиль, Костромские кружева, Палех, Мстера, Холуй, Федоскино, Жостково, Гусь-Хрустальный, Дымково, Хохлома - все это делало нас русскими. Обувь шить можно где угодно, например, в Китае, одежду - в Киргизии и в том же Китае. Но есть немало бытовых изделий, которые вросли в культуру народа, придумавшего их. Иx оригинальность неповторима.

Разговоры о дешевой рабочей силе в Китае очередной миф. В нестоличной России зарабатывают не больше, чем в КНР рядовые граждане. Суть - в организации производства, в экономической политике. В Китайской народной республике действительно на первом месте находятся интересы народа и страны. Экономическая деятельность в Китае имеет четкий ориентир и ориентир этот политический. В РФ экономическая выгода возведена в абсолютный критерий, что абсурдно, ибо экономика не является целью социального развития, она всего лишь средство этого развития. В Китае производитель максимально защищен от «наездов», «крышей» ему служит закон; порядок сношения с покупателем (заказчиком) предельно упрощен, что существенно сокращает время сделки и исполнения заказа, минимизирует непроизводственные затраты; отношения на рынке приближены к нормальным условиям его функционирования.

Российские законы регулируют рыночное пространство. Рыночное пространство формализованная юридически реальность, выстроенная условно по формуле «так должно быть», а это совсем не значит, что так оно есть и будет. Действительная рыночная реальность выстраивается в качестве среды взаимообусловленного сосуществования производителя, продавца (если им не выступает сам производитель) и покупателя - потребителя (включение перекупщика крайне нежелательно).

Россия всегда была сильна духом своих провинций. Столицы аккумулируют духовные силы окраин. Именно эти силы, как родники и малые реки, рождают большие. Нынешний расцвет Москвы и Петербурга не должен вводить в заблуждение. Реальная жизнь продолжается на просторах страны. 130 миллионов россиян попрежнему живут и работают там, где сосредоточена наша реальная народная сила. Что вселяет оптимизм? Сила характера людей. Ж.И. Алферова иностранные коллеги-ученые спросили: «Вы оптимист?» Он ответил: «Да, и мой оптимизм непобедим». «Почему?»- был следующий вопрос.
«Потому, объяснил известный физик, что вокруг меня все больше оптимистов. Пессимисты перебрались в ваши страны. С чем вас и поздравляю».

Власть не хочет видеть специфику российской модели нестабильного спроса на продукцию массового потребления: обувь, одежду, продукты питания, мебель, предметы бытовой необходимости. В Европе, США, Канаде во время кризиса снижается покупательская способность основной части населения и соответственно вниз идут цены на товары, компенсируя, хотя бы отчасти, удовлетворение необходимых жизненных потребностей. Динамика цен на товары народного спроса у нас всегда направлена в одну сторону - повышения. Колебания, конечно, наблюдаются, только заметны они в официальной статистике. Нормальный рынок не может изменяться независимо от состояния производства и потребления.

Российский рынок реагирует на изменение валютного курса, но опять-таки исключительно в плане роста цен. Создается впечатление, что рынком управляют «кукловоды». Версия не бесспорная, тем не менее, логически вполне допустимая. Власть активности не проявляет, объясняя тем, что стремление использовать регулятивные механизмы неизбежно приведет к обеднению рынка, дефициту товаров. На естественный вопрос: куда они денутся? Ответа нет. Действительно, попробуйте пояснить, куда уйдут с российского рынка китайские, турецкие, латино-американские товары, продукция Польши, Венгрии, Украины, Молдовы, Азербайджана, Узбекистана, Прибалтики? Кому еще они нужны?

Нам же нужна защита собственных производителей, кормящих, обувающих, одевающих нас. Россияне еще в последнее десятилетие прошлого века поняли преимущества отечественных пищевых продуктов. На очереди качество товаров легкой промышленности. И государство может способствовать устойчивому появлению их на прилавках магазинов. Что нужно для этого сделать? Разработать конкретную программу и жестко следить за ее реализацией чиновниками.

Программа возвращения на рынок российских производителей должна предусмотреть встречные шаги государства и предприятий. Возвращаться к тому, что и как шили прежде, бессмысленно. Требуется внутренняя перестройка производства, и рынок еe начинает ощущать. В России появились обувные и швейные предприятия, поставляющие продукцию вполне конкурентоспособную. Покупатель, правда, пока больше удивлен, 


\begin{tabular}{|c|c|c|c|c|c|c|}
\hline \multirow{4}{*}{ Impact Factor: } & ISRA (India) & $=3.117$ & SIS (USA) & $=0.912$ & ICV (Poland) & $=6.630$ \\
\hline & ISI (Dubai, UAE & $=0.829$ & РИНЦ (Russia & $=0.156$ & PIF (India) & $=1.940$ \\
\hline & GIF (Australia) & $=0.564$ & ESJI (KZ) & $=8.716$ & IBI (India) & $=4.260$ \\
\hline & JIF & $=1.500$ & SJIF (Morocco & $=5.667$ & OAJI (USA) & $=0.350$ \\
\hline
\end{tabular}

обнаруживая такие товары. Тем не менее, процесс пошел и его необходимо раскручивать.

Разумеется, речь не идет о дополнительном финансировании отрасли. «Отрасль»- понятие собирательное, обобщающее не достижения в ассортименте, дизайнерском искусстве, качестве, колорите. Под общее понятие попадают все производители определенной продукции. И те, кто стремится модернизировать производство, и те, кто рассчитывает не на свои силы, привык просить помощи у государства. Дополнительную финансовую помощь заслужили только новаторы, она действенна в адресном исполнении. Надо помогать сохранить традиционные народные промыслы. Они технически и технологически консервативны, инновационная деятельность здесь ограничена.

Правительство откликнулось на обращение о помощи ВАЗа, петербургских, уральских, дальневосточных предприятий, ссылаясь на их градообразующее и национальное значение. Bсе правильно, кроме одного, - о каком патриотизме, какой национальной гордости можно говорить, если россиянин будет одет и обут иностранными производителями, кормить и поить его также будут иностранцы. Великая держава начинается с малого - с осознания, что мы можем обычные для быта вещи делать сами не хуже кого-либо. Нас окружают мелочи, они во всем, и значение их не всегда видно в полной мере, но именно они создают наше настроение.

Устаревшую вазовскую продукцию обменивали на новые машины, государство субсидировало обмен. Старый костюм не сдашь в обмен на новый, и обувь, не способную удовлетворять требованиям, не отнесешь назад на фабрику. Есть иной вариант - государство способно компенсировать покупателю отечественной швейной и обувной продукции, предположим, 15 - 20 \% цены. Такая конкретная форма протекционизма повернет покупателя лицом к отечественным товарам, поможет ускорить сбыт продукции.

Не секрет, что российский потребитель обувной продукции, в отличие от производителя, рассчитывает проносить приобретенный товар не один и не два сезона. Изделиям потребуется обновление, ремонт. Почему бы, по примеру фирменных СТО, не организовать фирменную сеть по сопровождению эксплуатации обуви и одежды. Ремонт был бы дешевле и качественнее. Не менее важно и то, что такое обслуживание способствовало бы укреплению репутации производителя. Среднестатистический покупатель, приобретая отечественные туфли за 1500 - 2000 рублей, естественно, думает о том, что носить он будет их долго. Выбор адресов ремонта у него невелик: сделать самому, сходить к сапожнику-кустарю или в фирменную мастерскую. Мастерские целесообразно делать консолидированными, так будет менее затратно.[5]

Государство должно взять на себя и львиную долю расходов на организацию экономического и производственного ликбеза. Фирменная зарубежная обувь не стоит заявленной цены, поэтому так легко продавцы проводят различного рода акции, уценку. Не посвященный в хитросплетения рынка покупатель наивно полагает, что разница в цене пропорциональна разнице в качестве товара и копит деньги, берет кредит, чтобы не ошибиться с выбором, реклама постоянно напоминает ему «скупой платит дважды!» Рядом с брендовыми туфлями стоят модные, пошитые из натуральной кожи, со вкусом отделанные российские изделия, цена которых в полтора-два раза ниже, но кто бы объяснил, что они столь же качественны. Напротив, рекламная политика, оплачиваемая брендовыми компаниями, целенаправленно создает представление о невозможности производить на российских предприятиях качественных современных товаров.

На телевидении заработала программа «Среда обитания», развенчивающая мифы о полезности зарубежных продуктов. Нужна такая же программа, посвященная качеству продукции легкой промышленности. Роспотребнадзор регулярно ограничивает ввоз продуктов питания на территорию страны по причине превышения предельно допустимых норм содержания вредных, либо опасных для здоровья ингредиентов. Об опасности обуви и одежды, произведенной в Китае, Турции сообщают эпизодически в связи с какими-либо происшествиями резонансного характера. Невольно зарождается подозрение о странностях подобной политики. Кому-то выгодно выгораживать основных конкурентов отечественных производителей. Лоббирование в России узаконено и сделалось неплохим бизнесом для чиновников, прикрывающихся мировой практикой.

Разрозненным и еще слабым предприятиям сложно противостоять масштабной, хорошо отработанной политике, облегчающей оккупацию российского рынка чужеземными производителями. Этому способствует и отмена обязательности сертификации товара. Мера, вероятно, подходящая для Западной Европы с ее культурой потребления, но только не для России, заваленной контрафактной продукцией наиболее проблемных производителей. Ждать спада рыночного напряжения не приходится, чтобы отвоевать себе место на рынке, обрести устойчивость, нужно действовать напористо и комплексно, возрождать былой советский опыт организации работы с потенциальным 


\begin{tabular}{|c|c|c|c|c|c|c|}
\hline \multirow{4}{*}{ Impact Factor: } & ISRA (India) & $=3.117$ & SIS (USA) & $=0.912$ & ICV (Poland) & $=6.630$ \\
\hline & ISI (Dubai, UAE & $=0.829$ & РИНЦ (Russia) & $=0.156$ & PIF (India) & $=1.940$ \\
\hline & GIF (Australia) & $=0.564$ & ESJI (KZ) & $=8.716$ & IBI (India) & $=4.260$ \\
\hline & JIF & $=1.500$ & SJIF (Morocco) & $=5.667$ & OAJI (USA) & $=0.350$ \\
\hline
\end{tabular}

потребителем. Благо что развитие экономики открывает перспективу для такого рода деятельности.

Практика эффективна, когда ее путь освящает теория. На первый взгляд, обращение к теории в условиях анархии, творящейся на рынке, не совсем своевременно. На пожаре нужно тушить, а не рассуждать. Смотря, каков пожар. Иногда актуально и подумать, как следует действовать, разработать план, определить возможные сюжеты развития процесса. Что же касается завоевания рынка, то здесь без системного осмысления ситуации действовать никак нельзя. Получится слишком примитивно и неэффективно.

Экономика XX столетия сформировалась как экономика массового производства. Организация массового производства явилась выдающимся достижением, обеспечившим доступ к материальным благам значительной части человечества - товаров стало много, они сделались дешевыми. Но массовое производство актуализировало проблему качества произведенного товара.

Рост благосостояния, развитие образования, культурный прогресс, увеличивающийся технический ассортимент продукции закономерно сместили интерес потребителей в направлении качества предлагаемых на рынке изделий. Проблема качества из чисто производственной трансформировалась в социально-экономическую и политическую. «С помощью государственной политики, ориентированной на повышение качества, преодолевались крупномасштабные кризисы в Японии и Германии конца 40-х годов. Кризисные ситуации на рынках США и Европы, возникшие в конце 80-х - начале 90-х годов, заставили не только отдельные корпорации, но и целые страны - Швецию, Великобританию, США обратить внимание на улучшение качества как на единственное средство, помогающее национальной экономике устоять под натиском конкурентов».

Качество - системная характеристика товара, в ней товар предстает в своем целостном выражении. В наиболее общем виде «качество» есть «то, как писал Г. Гегель, теряя что, явление перестает быть собою». Разумно предположить, что понимание качества обусловлено природой явления. Явления естественного происхождения, то есть возникающие без участия человека, всецело объективны, и качество таких явлений исключительный результат их самодвижения.

Явления, связанные происхождением с деятельностью человека, так же качественны объективно, но объективность качества данных явлений дуалистична. К естественному основанию товара, произведенного человеком, добавляется объективированная часть, как правило, овеществленное выражение созидательной составляющей труда - знания, соображения, чувства, навыки, одним словом, то, что в совокупности предстает в понятии квалификационный вклад субъекта труда в процесс создания из предмета товара.

Качество предмета, превращенного в товар, формируется взаимодействием естественного, гуманитарного и социального. Вследствие чего у человека появляется естественное право видеть качество товара в системе своих, человеческих, ценностей. Отсюда мы получаем возможность сделать весьма важное заключение: качество природных явлений задано, качество сотворенных товаров (изделий) выстраивается одновременно с формированием способности чувствовать качество. Воспитание качественных представлений может быть стихийным, попутным, либо направленным, модулированным. Однажды известного французского художника Э. Делакруа спросили, мог бы он грязью написать портрет Мадонны? Да, ответил он, только мне нужен соответствующий фон. Воспитание потребителя - дело не только самого потребителя. Это еще и возможность для производителя иметь своего постоянного покупателя [6].

Исследуя проблему особенностей качества товаров, мы не нашли работ, посвященных системному анализу качества - рассмотрению его в системе, связывающей производство, рынок и потребление, а именно в ней содержится возможность найти ответ на коренной вопрос: как добиться устойчивого положения в неустойчивой среде существования.

В литературе в основном рассматривается качество производства товаров. И в этом направлении теория достигла той кондиции развития, которая требуется для практического прогресса в управлении качеством. Но этого явно недостаточно, чтобы управлять деятельностью предприятий с учетом волатильности рыночной динамики.

Востребованность товара, произведенного на предприятиях легкой и пищевой промышленности (и не только!), обусловлена не только экспертной оценкой качества, сделанной производством или по его просьбе. Судьба товара решается на перекрестке интересов и финансовых возможностей трех субъектов: производителя, потребителя и рынка, связывающего первых двух. Конкретно это выглядит так: каждый решает собственную задачу, но не должен абсолютизировать свой статус, помня о своем системном положении, обязывающем действовать с оглядкой на потенциал «партнеров», - готовы ли они к предполагаемому 


\begin{tabular}{|c|c|c|c|c|c|c|}
\hline \multirow{4}{*}{ Impact Factor: } & ISRA (India) & $=3.117$ & SIS (USA) & $=0.912$ & ICV (Poland) & $=6.630$ \\
\hline & ISI (Dubai, UAE & $=0.829$ & РИНЦ (Russia) & $=0.156$ & PIF (India) & $=1.940$ \\
\hline & GIF (Australia) & $=0.564$ & ESJI (KZ) & $=8.716$ & IBI (India) & $=4.260$ \\
\hline & JIF & $=1.500$ & SJIF (Morocco) & $=5.667$ & OAJI (USA) & $=0.350$ \\
\hline
\end{tabular}

решению проблемы. Вот почему так важно сегодня опережать практические шаги взвешенными оценками сложившейся ситуации.

Производитель традиционно озабочен думою, как обеспечить предельно возможное соответствие товарной продукции модельным образцам. В условиях массового производства такая проблема достаточно затратна, так как требует организации специальной развернутой службы, а главное, - где взять значительное количество квалифицированных работников. Японцы, столкнувшись с проблемой обеспечения производства квалифицированными исполнителями, вынуждены были решать ее весьма своеобразно - на свои предприятия, расположенные в соседних государствах: Малайзии, Таиланда, Сингапура, Индонезии, поставляли самую передовую технику, чтобы свести к минимуму ручной труд. Не все готовы последовать примеру Японии.

Линейное развитие экономики наверняка привело бы в тупик - массовое производство со временем стало бы крайне затратным. Никакая комплексная механизация и автоматизация не спасли. Во-первых, сокращение персонала вызвало бы рост безработицы со всеми вытекающими социальными негативами, во-вторых, все равно нужны были бы квалифицированные работники в большом количестве.

Спасение пришло от нелинейности, заложенной в диалектику прогресса. Экономика массового производства отработала свой ресурс и, подобно очередной ступени ракеты, потеряла необходимость существования. Экономическая парадигма сменилась. Нерациональное в различных аспектах - экологическом, гуманитарном, экономическом, массовое производство уступило место «рачительной экономике» (lean production). Производство принципиально меняет цель. Традиционная задача изготовления большого числа однотипных изделий, отвечающих требованиям нормативной документации, из которых потребителю предлагается выбрать наиболее подходящие, заменяется задачей изготовления именно такого изделия, какое нужно данному потребителю и именно в требуемом объеме и в определенное время.

«Рачительная» (щадящая) экономика акцентирует внимание производителя на состоянии потребительского настроения. Производителю необходимо изучать спрос, искать свою нишу в потребительском спросе, «воспитывать» с помощью рекламы, просветительской работы, организации сервисного обслуживания своего покупателя.

Новая экономическая философия сближает производителя и потребителя, подчеркивает диалектичность их взаимоотношений - они противоположности, но такие, которые существуют только в единстве. Изначально производитель и потребитель вообще были в одном лице. Разделение труда и повышение его производительности физически отделили одного от другого, однако суть отношений не изменилась. Рынок их противопоставил, усложнив систему пространственных отношений посредническими, транспортными и прочими инструментами. Задача, объединяющая производителя и потребителя, заключается в том, чтобы не упускать друг друга из вида, расчищать рыночные надстройки, делать себя непосредственными финансовыми партнерами, снижая финансовую нагрузку на производство.

Вместе с тем производитель и потребитель в системе рыночных отношений, порожденных товарной экономикой, противостоят один другому, поэтому их понимание качества производства, товара совпадают частично, что также важно учитывать, обустраивая присутствие на рынке, надеясь закрепиться там на всю оставшуюся жизнь.

Общими признаками качества товара для производителя и потребителя будут его полезность, удобность, гигиеничность, эргономичность, устойчивость к деформации, простота в обращении, соответствие моде. Потребителя, в отличие от производителя, мало интересует качество производства товара, хотя, «раскрученный», то есть просвещенный потребитель не должен, по логике изменения вещей, совсем игнорировать технологию, организацию производства. Связь качества изделия и качества производства носит причинноследственный характер, и это вполне доступно дилетантскому пониманию.

Со своей стороны производитель рискует оказаться не у дел, если недооценит специфику представлений о качестве товара потребителей. Э. Деминг - автор классификации «смертельных болезней» для производителя - среди семи смертей назвал под №1 «ориентирование производства на такие товары, которые не пользуются спросом на рынке», то есть не востребованы потребителем; №2 - «акцент на краткосрочные прибыли и сиюминутные выгоды». В обоих случаях производитель допускает одну и ту же методологическую ошибку - он изымает свою деятельность из системы взаимоотношений, «свой участок» делает всеобщим, за что и расплачивается полной мерой.

Представление потребителя о качестве товара потребления менее объективно, в сравнении с пониманием производителя. Добросовестный производитель, принимая профессиональные обязательства, привлекает научные знания, независимые экспертизы и т.п. Потребитель, в противоположность 


\begin{tabular}{|c|c|c|c|c|c|c|}
\hline \multirow{4}{*}{ Impact Factor: } & ISRA (India) & $=3.117$ & SIS (USA) & $=0.912$ & ICV (Poland) & $=6.630$ \\
\hline & ISI (Dubai, UAE & $=0.829$ & РИНЦ (Russia) & $=0.156$ & PIF (India) & $=1.940$ \\
\hline & GIF (Australia) & $=0.564$ & ESJI (KZ) & $=8.716$ & IBI (India) & $=4.260$ \\
\hline & JIF & $=1.500$ & SJIF (Morocco) & $=5.667$ & OAJI (USA) & $=0.350$ \\
\hline
\end{tabular}

профессионалу-производителю, является в общей массе «любителем». Его взгляды на качество товара, упрощенно говоря, обывательские, основываются не на научных знаниях, а на здравом смысле. В них преобладает прагматический подход, субъективированная оценка. Теоретически, правым всегда должен быть производитель; практически - тогда не было бы нормального рынка, поэтому всем известно противоположное утверждение: покупатель всегда прав.

Доминирование прагматического подхода к качеству товара у потребителя - своего рода издержка в отношениях основных рыночных субъектов. С этим приходится мириться, иначе, по-видимому, невозможно выстроить системообразующее звено рыночной практики. Потребитель, в качестве покупателя, ограничен платежеспособностью. У производителя есть определенные теоретические ресурсы, например, увеличить объем продаж, оборотные средства, сократить расходы и т.д. Потребитель-покупатель реальных резервов не имеет - кредиты только увеличат его расходы, причем в РФ очень существенно. Исходя из своей ситуации, потребитель на качество товара смотрит через прицел количества рублей, выставленного продавцом как эквивалент качества. К сказанному добавим тот скепсис, который пробуждает в сознании покупателя назойливое повторение: «цена соответствует качеству». Цена может быть эквивалентна качеству только в частном случае. На рынке кормится свора посредников.

«Качество» и «цена»- опорные понятия и для производителя, и для потребителя, но вплетены в системные соображения они поразному - в зависимости от противоположности рыночного положения. Каждый из субъектов измеряет качество товара, исходя из собственного статуса.

Третий субъект отношений производителя и потребителя, и еще один «оценщик» качества товара - это рынок, являющийся инструментом регулирования отношений производителя и потребителя. Роль рынка исторически укреплялась по мере развития национальных экономик, создания транснациональных компаний. Рынок из эпизодического ограниченного во времени инструмента, сделался вполне самостоятельным экономическим явлением. Разрастание рынка сопровождалось его структурной эволюцией, он выстроился в итоге в сложную пирамиду непосредственного, опосредованного участия; розничная торговля достроилась оптовой; сделки из настоящего времени ушли в будущее. На рынке обозначился лидер - рынок финансовых операций, что надо рассматривать как симптом, ибо финансовый рынок, по определению, отдален от предмета и качество здесь представлено обобщенно, условно.

«Качество товара», с точки зрения рынка, это признак ликвидности товара. Товар не залеживается, следовательно, искомое качество достигнуто. Рынку нет дела до того, удовлетворяет ли действительно качество товара потребителя. На рынке «король» не покупатель, а продавец и критерий качества - время реализации товара. Что будет потом? - продавца не очень волнует. Вот почему распространена такая «смертельная болезнь», как стремление к сиюминутному результату. Тем не менее «рыночная теория» качества имеет место быть и с ней необходимо считаться при определении экономической политики.

Производство, потребление и рынок, оказавшийся субъектом их отношений культурные феномены, их историческая конкретность обусловлена временем, национальными и региональными особенностями развития. Словосочетания «культура производства» и «культура потребления» давно и прочно вписались в профессиональную лексику, что не скажешь о «культуре рынка». Различие объяснить не представляет труда. Производство и современное потребление базируются на научных знаниях, отражающих объективный порядок вещей, в них несложно проследить влияние культурных традиций.

История рынка не столь велика и отношение к рынку несколько иное в культуре. Рынок XX и нового столетия бесспорно вобрал в себя элементы культуры, однако оказался той самой деятельностью, которой не присущи фундаментальные культурные ценности. Девиз российских купцов: «Наша цель - прибыль, но честь выше!» прижился благодаря заложенному и культурно оформленному лукавству. Честные и совестливые продавцы на рынке никогда не задерживались - не их место. Если причислить искусство обманывать к совокупности культурных феноменов, то рынок является формой реальности массового культурно оформленного обмана. Обманывают всех, всегда и по-всякому. И в обмане на рынке искусства не меньше, чем в театре, где тоже, по-своему, обманывают.

Субъективированный, с неустойчивой, разнонаправленной динамикой движения, рынок слабо предсказуем. Те попытки, которые предпринимаются в прогнозировании поведения рынка, малопродуктивны именно по причине недостаточности объективных показателей системного вида. Так что резервы рынка, как области управления реальным качеством, невелики, тем более в отсутствии желания государства 


\begin{tabular}{|c|c|c|c|c|c|c|}
\hline \multirow{4}{*}{ Impact Factor: } & ISRA (India) & $=3.117$ & SIS (USA) & $=0.912$ & ICV (Poland) & $=6.630$ \\
\hline & ISI (Dubai, UAE & $=0.829$ & РИНЦ (Russia & $=0.156$ & PIF (India) & $=1.940$ \\
\hline & GIF (Australia) & $=0.564$ & ESJI (KZ) & $=8.716$ & IBI (India) & $=4.260$ \\
\hline & JIF & $=1.500$ & SJIF (Morocco & $=5.667$ & OAJI (USA) & $=0.350$ \\
\hline
\end{tabular}

активно вмешиваться в архитектонику рыночных отношений.

У конкретного предприятия (лучше объединения, группы предприятий) перспективы продвижения товарной продукции на рынок связаны с разработкой ресурсов понимания качества в координатах производства - искать качественный компромисс, и воспитанием своего потребителя.

Европейским и североамериканским производителям проще обустраиваться на рынке со своими товарами. Накоплен в течение двухтрех столетий опыт общения с потребителем, потребитель разобрался с производителями, нашел «своих» по интересам и карману; рынок сбалансировался, приспособился к требованиям законодательства; государство не прессингует рынок, производителя и покупателя, но там, где присутствует, делает это жестко. С коррупцией, наездами, монопольными притязаниями не покончено, однако борьба ведется реальная, а не декоративная, бутафорская, что существенно облегчает доступность рынка, унифицирует условия конкуренции.

Среди главных проблем европейских теоретиков и практиков удовлетворенность качеством товаров потребителя. Проблема, в схематичном выражении, простая - надо качественно удовлетворить потребность конечного покупателя в товаре. При ближайшем анализе простота, оказывается, условной композитивной, чтобы получить желаемый результат, придется выстроить на рынке ансамбль из ценности товара (1), цены (2) и покупательской готовности потребителя. В этом смысле рынок действительно приобретает узловое значение для экономического развития. Данным акцентом экономической политики производителей можно объяснить концентрацию интересов на потребителя. Потребителя не актуально ждать, его необходимо активно искать и «обращать в свою веру».

В зарубежных аналитических обзорах появилась информация о том, что авангардно настроенные маркетологи, представляющие крупные компании, производящие товары массового спроса, предлагают существенно расширить формат соучастия с потребителями продукции вплоть до обсуждения рекомендуемой цены на изделие экономряда. Идея вполне разумная и практически осуществимая без особых затрат. Покупательские конференции здесь мало реальны, но развернутая практика проведения акций, рекламные действия с устройством показа товара, сообщением расчетной цены и просьбой дать потребительскую оценку планам достаточно перспективны и могут быть эффективными. Не надо недооценивать современного покупателя, его финансовой готовности, как не следует с завышением цены заставлять его оплачивать неквалифицированную политику производителя. Согласованные цены тоже не смертельны для предприятия. Есть всегда неиспользованные ресурсы: материаловедческие, технологические, организационные, активизируя которые производитель делает процесс рентабельным. За устойчивое положение на рынке в условиях усиления конкуренции и волатильности приходится платить. Возможно имеет смысл рационально осовременить то, что на «рынке» типа базар зовут «поторговаться».

Качество продукта, в практическом сознании, определяется через его способность удовлетворить потребности и ожидания конкретного потребителя. Качество продукта складывается из множества полезных свойств. На рис.1 выделены основные качественные свойства товара.[7]

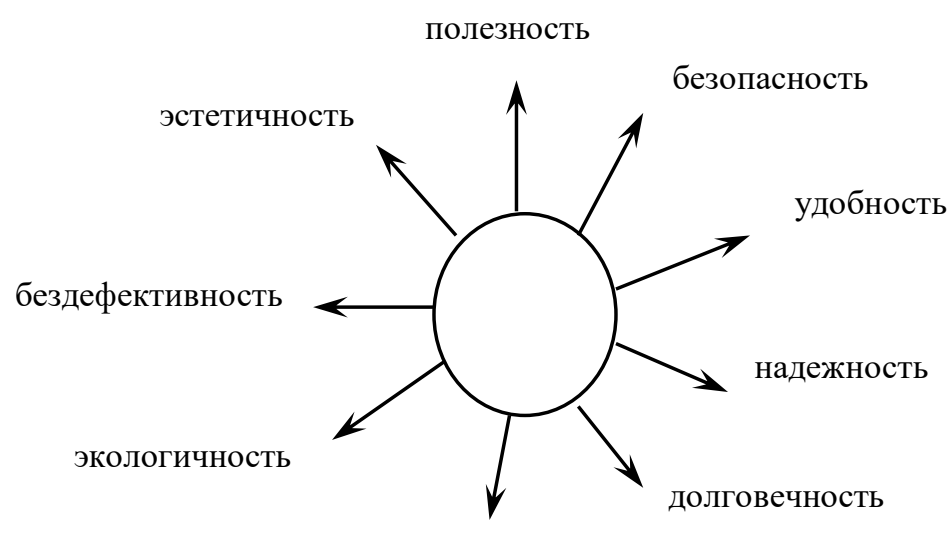

ремонтопригодность

Рис. 1. Основные качественные свойства товара. 


\begin{tabular}{|c|c|c|c|c|c|c|}
\hline \multirow{4}{*}{ Impact Factor: } & ISRA (India) & $=3.117$ & SIS (USA) & $=0.912$ & ICV (Poland) & $=6.630$ \\
\hline & ISI (Dubai, UAE & $=0.829$ & РИНЦ (Russia & $=0.156$ & PIF (India) & $=1.940$ \\
\hline & GIF (Australia) & $=0.564$ & ESJI (KZ) & $=8.716$ & IBI (India) & $=4.260$ \\
\hline & JIF & $=1.500$ & SJIF (Morocco & $=5.667$ & OAJI (USA) & $=0.350$ \\
\hline
\end{tabular}

Новое для экономической теории понятие «ценность продукта» определяется как «совокупность ожидаемых потребителем параметров качества необходимого ему продукта». Из понятия «ценность продукта» «вырастили» «Дерево потребительской удовлетворенности».

Ценность продукта складывается из степени необходимости его потребителю и уровня качества (наличием требуемых характеристик у товара). На решение о покупке также влияют:

- уверенность покупателя в поставщике;

- $\quad$ доверие к производителю;

- информация, поступающая от других потребителей;

- накопленный опыт использования подобного продукта.

Потребитель предпринимает решение о покупке товара, взвесив отношение предложенной цены продукта с предполагаемыми затратами. Чем выше уровень удовлетворенности потребителя, тем больше возможностей развития бизнеса, устойчивее его рыночное положение.

\section{Основная часть}

В истории проблемы качества выделяются два периода. В течение первого серьезный интерес к тому, что есть качество, был ограничен в основном профессиональной теорией. Качество и его системное положение пытались определить философы, однако, и в многочисленных философских спорах понятие «качество» не принадлежало к числу главных проблем.

Актуализация теории качества оказалась в зависимости от степени разработанности системообразующего философского понятия «бытие» в контексте базовых производных от него понятий, т.е. тех понятий, которые помогают осуществить восхождение от предельно абстрактного утверждения существования с единственным отличающим свойством быть, существовать, к конкретному пониманию с устоявшемся содержанием, благодаря ответам на производные вопросы, такие, как «Из чего есть все?», «За счет чего все существует?», «Есть ли небытие?», «В каких системных формах бытие обретает свою определенность?».

По-видимому, именно последний из перечисленных вопросов вывел философию на «тропу» того толкования качества, которое «зацепило» не только тех, кто «обустраивал» принципиально новый в человеческой истории тип мировоззрения.

Логично предположить, что проблема субстанции бытия, как первый шаг к теории качества, вряд ли кого волновал за пределами ограниченного сообщества философов. Все свидетельствует о том, что интересно это было тем, чей взор был обращен в Космос, в глубины его конструкции, а подавляющее большинство земляков философов находилось во власти земных проблем.

Проблема качества жизни решалась в соответствии с социокультурной архитектурой общества. Проблема эта бесспорно имела место, но вызреть в актуальную для общества не могла. Причина проста - отсутствие достаточного уровня массовой востребованности качественного продукта.

Проблема качества обрела масштабы социальной актуальности в условиях перехода к экономике массового производства, демократизации общественных отношений, развития просвещения, доступности образования и других культурных ценностей. Чтобы вопрос о качестве сделался одним из наиболее важных для общества, нужно было, чтобы он стал актуальным для большинства тех, кто образует это общество. Без права на свободу и покупательской способности делать выбор, «качество» не способно быть среди приоритетов массового сознания. Элитные же запросы на качество разрабатываются в эксклюзивных, нетрадиционных теориях, главная цель которых не достижение истины, а удовлетворение потребности заказчиков.

Разумеется, о качественных и количественных характеристиках явлений естественного и искусственного происхождения знали задолго до того, когда эти признаки актуализировались в общественном бытии и отражающим его развитие сознании, но, в свете нашего исследования, существование знания качества де факто не столь значимо. Предмет исследования не осознание качества, а развитие понимания качества на разных горизонтах общественной истории.

Развитие - универсальное состояние всего существующего от простейших материальных субстратов до высших форм мышления. Совершенствовались и качество, и количественное его выражение, прояснялась зависимость качественно-количественных изменений. Смещались акценты внимания с количества на качество. Доказав свою эволюционную прочность, человечество переключалось на принцип: «брать не числом, а умением». На смену борьбы за выживание пришло стремление к качественному уровню жизни в широком диапазоне толкования. Началась борьба за достойную качественную жизнь.

Как показывает история, уйдя от дикости и варварства, заложив основы цивилизации, люди заметно изменились во внешних формах своего проявления, но в недра человеческой натуры 


\begin{tabular}{|c|c|c|c|c|c|c|}
\hline \multirow{4}{*}{ Impact Factor: } & ISRA (India) & $=3.117$ & SIS (USA) & $=0.912$ & ICV (Poland) & $=6.630$ \\
\hline & ISI (Dubai, UAE & $=0.829$ & РИНЦ (Russia & $=0.156$ & PIF (India) & $=1.940$ \\
\hline & GIF (Australia) & $=0.564$ & ESJI (KZ) & $=8.716$ & IBI (India) & $=4.260$ \\
\hline & JIF & $=1.500$ & SJIF (Morocco & $=5.667$ & OAJI (USA) & $=0.350$ \\
\hline
\end{tabular}

цивилизация проникает медленно и тяжело. Биологическая история заложила в природу человека активное начало, совмещенное с развитой способностью мышления, заметно превосходящей все иные виды отражения. Но вся эта надстройка сформировалась над достаточно жестким животным каркасом, подчиненным системной цели выжить в борьбе. Условия борьбы трансформировались, внося коррективы в средства и формы, однако сама природная база оказалась весьма инерционной.

Переход от естественного эгоизма биологического уровня к разумно-деятельному эгоизму, несмотря на известные цивилизационные средства культивации, не отвечал прогнозам ни романтиков, ни реалистовоптимистов. Цивилизация отметилась не цивилизационными формами отношений в движении к качественной жизни, чем еще больше актуализировала интерес к качеству. Чтобы стать в ряд с самыми важными проблемами, качество должно было предстать в нескольких функциях: как цель, как средство, как условие развития всех социальных субъектов на всех уровнях жизнедеятельности.

История для историков - события и участники, выстроенные во временной последовательности, своего рода хронология значимых фактов общественной и, отчасти, личностной жизни. Философ и специалистнеисторик видят в истории свои интересы. Философский и специальный интерес к истории продиктован потребностью понять диалектику процесса применительно к деятельности человека. Специалист стремится обнаружить в прошлом тенденции пути решения своей проблемы, подчас далеко не частной.

Интуитивно еще на заре цивилизации термин история (historia) трактовался в смысле исследования искомого процесса в противоположность хронологическому описанию. У ионийцев повествование, рассказ о прошлом именовали логосом (logos). Лишь спустя время, уже в трудах основоположников философии логос приобрел современное значение - мысль, идея. И Геродот, и Фукидид понимали историю как осмысление хода событий прошлого, необходимое для «наставлений в образе жизни» тем, кто живет в настоящем. Пройдя испытание временем, историзм укрепил свои позиции, стал идейной базой культурной памяти. Н.А. Бердяев утверждал: «От первых дней Творения...человек находится в историческом и историческое находится в человеке. Погружение в глубь времен есть погружение внутрь себя». ${ }^{1}$
Прошлое растворяется во времени, оставляя нам, наряду с памятью о былом, думы о настоящем и ответственность за будущее. Новое всегда относительно. Гете был прав, говоря, что все умное уже известно, надо только еще раз это продумать.

История - клад идей, золотая жила для мыслящего человека, чем бы он ни занимался. Различное отношение к истории есть совокупный результат действия двух причин: первая толкование времени, вторая - себя во времени. В дохристианский период истории время трактовали циклически, представляя его как сумму повторяющихся замкнутых на себя циклов. С христианством взгляд на время поменялся. Время предстало в качестве восхождения к бесконечному, разделившись на конечное земное и бесконечное внеземное. Противоположение циклического и вне циклического рассмотрения времени характерно для теологической теории. Нас оно не интересует, впрочем, как и свойства времени в их абстрактном виде.

После Г. Гегеля и К. Маркса актуально не представление о чем-то вообще, а погружение в конкретно-предметное, либо конкретноисторическое состояние того, что оказывается объектом исследования. В случае со временем, актуально анализировать не столько его универсальные свойства, определять, куда и как оно движется. Важно то, что все существующее во времени может состояться, только соответствуя этим объективным характеристикам времени. Существовать во времени, значит обладать свойствами времени. Данное положение универсально и для бесконечного многообразия отдельных явлений, и для присущих им признакам бытия, к которым принадлежат «качество» и «количество». ${ }^{2}$

Стандартное понимание закона перехода количественных изменений в качественные упрощает взгляд на их связь. И Г. Гегель, и Ф. Энгельс были далеки от того смысла, который распространялся под прикрытием диалектической теории развития. Количество в качество не переходит непосредственно. Новое качество, качественное состояние возникает как переход из предшествующего качества. В изменившихся количественных условиях мера исчерпывает резерв устойчивости функционирования.

Мера - «качественное количество», она указывает на пределы изменения количества без существенных последствий для данного качества явления. Выход количественных показателей, необходимых для достигнутого качества, за 


\begin{tabular}{|c|c|c|c|c|c|c|}
\hline \multirow{4}{*}{ Impact Factor: } & ISRA (India) & $=3.117$ & SIS (USA) & $=0.912$ & ICV (Poland) & $=6.630$ \\
\hline & ISI (Dubai, UAE & $=0.829$ & РИНЦ (Russia & $=0.156$ & PIF (India) & $=1.940$ \\
\hline & GIF (Australia) & $=0.564$ & ESJI (KZ) & $=8.716$ & IBI (India) & $=4.260$ \\
\hline & JIF & $=1.500$ & SJIF (Morocco & $=5.667$ & OAJI (USA) & $=0.350$ \\
\hline
\end{tabular}

границы меры неизбежно влечет качественные преобразования. Одновременно с потерей прежнего качества идет процесс рождения из него, на его основе нового качества, соразмерного изменившемуся количеству. Ключевое положение во взаимоотношениях качества с количеством занимает мера. О мере же специалисты по качеству предпочитают всерьез не рассуждать, сводя меру к количественным стандартам. Будто мера - это какое-то проходное состояние системы «качество-количество». Надо четко понимать объективную и функциональную роль меры в управлении как качеством, так и количеством.

«Мера» не принадлежит ни качеству, ни количеству. Она выражает системный способ отношений качества и количества, связывает их. Итак, первое: количество и качество взаимодействуют через меру, мера опосредует их связь. Какую «выгоду» извлечет из настоящего заключения специалист-практик?

Рынок, по сути своей, не способен быть контролером меры, регулирующей отношения в системе «количество - качество». С приобретением оптовых форм развития, господствующего положения финансового капитала и его естественного порождения масштабных спекуляций и посредничества, современный рынок противопоставил себя производству и потерял интерес к состоянию производства. Рынок, используя специфику массового производства, насытился в меру своей извращенности и может позволить себе задавать качественные характеристики товаров.

Государство ведет себя на рынке, будто воспитатель в детском саду. Интересы рынка оно ставит выше интересов производителей и массового потребителя. Под «крышей» генеральной идеи - рынок тянет за собой производство, идет срастание рынка и государства. Качество - количественные оценки оказываются оттиснутыми в зону субъективного произвола.

До тех пор, пока теория качества системно не выстроена, теория управления качеством будет строиться на эмпирических началах, которые не в состоянии охватить предмет управления в целом, и относительно значимы в ограниченной специфике производства. За неимением ничего лучшего ими пользуются, экстраполируя локальный опыт на другие условия, получают эффект за счет добавленных мер по адаптации, к сожалению, опять-таки временный и частичный.

В калейдоскопе истории смены способов управления качеством можно различить определенную логику. Жизнь же требует не «определенной» логики, а логической определенности в форме целостной, системно обоснованной теории качества в качестве методологической опоры построения универсальных принципов теории управления качеством. Исходной здесь должна быть идея системности отношений «качество-количество» в рамках меры их сосуществования.

Раскрыться в полной мере качеству помогает количество. Качественную вещь можно создать и в одном экземпляре, но, чтобы раскрыться качественному потенциалу производителя, единственного экземпляра (или произведения) явно недостаточно. Фирма Фаберже обеспечила себе известность уже первым брендовым изделием, но брендом сделалась за счет последующих успехов в создании коллекции.[8]

Примером системного понимания качества в рамках меры - мерностной определенности служат мелкие серии, выпуск коллекционных монет, медалей. Качество фиксируется в границах количественной величины, служащей мерой его выражения. Дело здесь не только в обеспечении условий преференции для vipпотребителя продукции. Значима также зависимость объективных признаков качества от количества произведенных экземпляров. Массовое производство объективно сопряжено со снижением качества продукции. Мера пограничная служба качества, переход за мерное количество есть преступление против качества.

Массовый отечественный производитель вряд ли интересуется теорией качества. Она для него не актуальна. Если все же случайно кто-то наткнется на наши рассуждения, то, вероятнее всего, улыбнется их наивности. Пытаться с помощью теории перестроить российский рынок, придать ему цивилизованный вид - классическое донкихотство. Сначала надо организовать рыночное пространство посредством политической воли, законодательных инициатив и действенного, а не бутафорского контроля за узаконенным порядком, вернуть на рынок производителя товара, убрав немереное количество посредников.

Настоящий производитель не заинтересован в спекулятивных операциях. Ему для устойчивого развития необходим свой потребитель, который, кстати, в свою очередь, совсем не против иметь своего определенного и доступного производителя в рамках нравственно - правовых отношений.

Чувство национального достоинства воспитывается историей и существующей реальностью. В школе можно учиться по самому лучшему учебнику истории, но кроме школьных уроков истории есть текущая жизнь, впечатляющая сильнее исторических экскурсов. На Востоке говорят: «сколько раз не повторяй халва, во рту сладко не будет». Теория всегда считалась лучшим практическим руководством, 


\begin{tabular}{llllll} 
& ISRA (India) $=3.117$ & SIS (USA) $=\mathbf{0 . 9 1 2}$ & ICV (Poland) & $=\mathbf{6 . 6 3 0}$ \\
Impact Factor: & ISI (Dubai, UAE) $=\mathbf{0 . 8 2 9}$ & PUHЦ (Russia) $=\mathbf{0 . 1 5 6}$ & PIF (India) & $=\mathbf{1 . 9 4 0}$ \\
& GIF (Australia) $=\mathbf{0 . 5 6 4}$ & ESJI (KZ) $=\mathbf{8 . 7 1 6}$ & IBI (India) & $=\mathbf{4 . 2 6 0}$ \\
& JIF & $=\mathbf{1 . 5 0 0}$ & SJIF (Morocco) $=\mathbf{5 . 6 6 7}$ & OAJI (USA) & $\mathbf{0 . 3 5 0}$ \\
\hline
\end{tabular}

правда, в нормализованных обстоятельствах деятельности. Уходя в нелегальное и полулегальное положение, производитель отчуждается от качества и, естественно, от теории качества. Далее происходит подмена качества псевдо качеством и растут затраты на рекламную бутафорию.

Качество действительно предполагает серьезные затраты, но оно гарантирует устойчивую рыночную позицию. Работая на качество, производитель создает уверенность в своем и национальном будущем. Правильно выстроенное понимание качества гарантирует перспективу даже в условиях отечественного полу рынка.

Постараемся в порядке введения в теорию качества сформулировать практически значимые фундаментальные положения:

- Качество не сводится к сумме важных для бытия товара свойств; оно - их своеобразная комбинация, выстроенная на базе обычно двух признаков - более общего и более специфического. К примеру. Обувь - «одежда для ног», шляпа - «одежда для головы», кашне «одежда для носа и шеи» и т.п. Следовательно, центральное внимание нужно уделить именно им.

- Качество допускает изменения, не ведущие к утрате качества, но снижающие или повышающие его потребительскую ценность; качество - совокупность качественных состояний, удовлетворяющих в разной степени системообразующим признакам. «Люфт» качества позволяет маневрировать в процессе создания продукта с заданным качеством в зависимости от конкретных возможностей производителя и потребителя.

- Качество не существует вне количества, они - диалектические противоположности, их противопоставление действительно только в пределах единства, из чего следует, что, создавая качество, необходимо закладывать в качественные характеристики количественное выражение как в отношении отдельных свойств товара, так и количества товарных изделий. А.К. Саврасов, оказавшись в тяжелой жизненной ситуации, сделал несколько копий своей знаменитой картины «Грачи прилетели». Как правило, авторские копии имеют высокий уровень мастерства и за них хорошо платят. Заплатили и художнику. Когда же задали вопрос П. Третьякову: купил бы он копию Саврасова, случить что с оригиналом? Ответ Третьякова оказался прогнозируемым по категоричности нет! Качество требует не только мастерства, но и вдохновения. Вдохновение с повторами выгорает. Качество всегда количественно, а количество - качественно.

- Качество и количество связывает мера, о которой чаще всего забывают. Между тем, определяя качество, нужно одновременно думать о его мерности, и с позиции рыночной конъюнктуры, и с точки зрения самих признаков качественности. «Качество» конкретизируется в представлении о «качественности». «Качество»понятие, отражающее модельный образ товара, «качественность» - определяет количественные пределы действительности и разумности качества (физического и морального статуса товара).

- Качество и представление о качестве относятся к явлениям устойчивым, однако время изменяет и их. Первоначально качество отождествляли со значением. Критериями качества были полезность и величина предмета, отношения. $\mathrm{C}$ развитием сознания и практических возможностей сложились основания сравнения и выбора. Качество относительно обособляется от количества. Совершается дифференциация полезности, переосмысливается участие в качестве количественных признаков. Эволюция понимания качества непосредственно обусловлена воплощением в деятельность творческого потенциала. Расхождение в интенсивности продвижения вперед индивидуального мастерства, интересов тех, кто призван расчищать путь таланта и массового сознания усложняет понимание качества и процесс управления качеством. Особое значение приобретает конкретность толкования качества, в частности, такого его базового признака, как объективность. Общественная теория бытия выстраивается на естественно-исторической основе - канву ее заложила природа, a исторический рисунок сотворил человек. В естественной среде все признаки, включая и такие синтетические, как качество, - продукты стихийного движения. В обществе всякое явление проходит через деятельность, включает в себя и в свое качество мыслительный и физический труд человека. Определение качества явлений, созданных человеческой деятельностью, невозможно без социокультурной конкретизации. В связи с чем актуализируются два вопроса: в каком статусе и в какой мере сознание входит в то, что традиционно принято называть качеством вещей (с услугами ясности больше)?

Ответы на оба вопроса надо искать в философской теории отчуждения. Теория отчуждения прямого отношения к теории качества не имеет. В ней ключи к методологии построения теории качества.

Из вышерасположенных рассуждений понятно, что авторы- не идеалисты, скорее балансируют на грани пессимизма и оптимизма. Они критично воспринимают современный прагматизированный подход либераловрыночников к научной и философски обоснованной теории. Облегченный вариант 


\begin{tabular}{|c|c|c|c|c|c|c|}
\hline \multirow{4}{*}{ Impact Factor: } & ISRA (India) & $=3.117$ & SIS (USA) & $=0.912$ & ICV (Poland) & $=6.630$ \\
\hline & ISI (Dubai, UAE & $=0.829$ & РИНЦ (Russia) & $=0.156$ & PIF (India) & $=1.940$ \\
\hline & GIF (Australia) & $=0.564$ & ESJI (KZ) & $=8.716$ & IBI (India) & $=4.260$ \\
\hline & JIF & $=1.500$ & SJIF (Morocco) & $=5.667$ & OAJI (USA) & $=0.350$ \\
\hline
\end{tabular}

теории, когда вырванный из общей теории фрагмент превращают в самую теорию и подгоняют под конструкцию извращенного в угоду спекулянтам рынка, экономистовтеоретиков и поставщиков качественного суррогата на отечественные прилавки устраивает. Как долго российская экономика сохранит подобную конфигурацию, нам (и не только нам) знать не дано, однако мировой опыт экономического развития на различных стадиях экономических отношений свидетельствует, что переходные периоды проходят и со временем экономическая жизнь приходит в нормальное состояние.

Траектория процесса отчуждения творчества человека в то, что существует вне его, должна с необходимостью сохранять и активировать способность к созиданию. В отличие от бытия природы, бытие человека не субстанционально. Оно не самодостаточно и может иметь место исключительно благодаря взаимообмену изначально с природой, затем с обществом, через которое выстраиваются человеческие отношения друг к другу и взаимодействие с природой. Инструмент, обеспечивающий бытие человека труд, высшее качество труда проявляется в деятельности.

Качественность деятельности, с одной стороны, показатель качества жизни человека (так должно быть!), с другой - качественная деятельность встраивается в качество того, что он преобразует. Качество «первой» (естественной) природы формируется само по себе как совокупность объективно связанных естественных признаков, стихийно. Качество «второй» (реконструированной, приспособленной человеком под свои интересы) природы - синтетическое. Оно представляется двойной спиралью, образуемой естественными признаками природного материала (возможно - в отношениях людей, знаниях, выраженных опосредованно) и качественными характеристиками человеческой деятельности знаниями, эмоциями, волей, ценностной ориентацией, мастерством. В итоге качество продукта в отличие от самого продукта воплощает качество личности.

Личность отчуждается в качестве и потому, в принципе, отчуждение естественно и не угнетает личность. Негативное следствие отчуждения вызвано непропорциональностью возмещения утраченной энергии деятельности. Обнаружив не качественность товара, скрытый брак производства, обманные действия продавца, нормальный покупатель расстраивается, в первую очередь, из-за собственного некачественного решения. Иные убытки сделки чаще всего возмещаются. Остается ощущение несовершенства собственного вкуса и знаний.
Качество всего, что создано деятельностью, включает свойства деятельности как практической, так и духовной в объективированном (предметном либо функциональном) выражении. Отсюда следует вывод о необходимости формировать и направлять развитие способности массового сознания к качественной оценке товаров: определенный опыт в советское время был и показал свою действенность: «кружки», «школы», «университеты», в том числе инициируемые телевидением и радио. Место системного просвещения массового потребителя, профессиональной помощи в развитии культуры качественной избирательности, сегодня в эфире забито агрессивной рекламой, качество которой не контролируется или контроль не соразмерим с размером обмана. Кто должен быть главным просветителем? Производитель и только он, ибо лишь ему в полной мере, по логике становления понимания, следует знать, что такое качество. Браться за производство товара, не осмыслив конкретность качества данного изделия, означает профессиональный провал на рынке. Выпуск же продукта с бутафорским качеством преследуется законом, правда, формально и постфактум. На последнее и надеются поставщики псевдо качественных товаров.

Проблема качества теоретически остается разработанной односторонне, потому что отсутствует нормальная организация производства и сбыта качественной товарной продукции. Нынешнюю практику удовлетворяет такая степень определенности в теории качества. Теория управления качеством упрощена до концепции контроля за условиями качественного производства. В то время как нет системности понимания, что такое качество товара, производством заправляет рынок. На рынке правят спекулянты - посредники. Государство стремится минимизировать свою экономическую функцию до сбора налогов. Реальной деятельности, направленной на придание рынку цивилизованной формы «купли-продажи» на принципах действительной свободы конкуренции нет. За признаками, обязательными для качества, надзор ограничен до уровня практической бесполезности. Рынок диктует порядок местным и региональным органам управления. Директор магазина управлял оборонным ведомством. Культура производителя и потребителя мало кого интересует, не до них. А ведь порядок внешний начинается с порядка внутреннего, с осознания «политического момента», обусловленного экономическим положением.

Исторически понимание качества и конкретности его реальности, представленной в товаре, отражают экономическое и культурное развитие общества. Качество во времена 


\begin{tabular}{|c|c|c|c|c|c|c|}
\hline \multirow{4}{*}{ Impact Factor: } & ISRA (India) & $=3.117$ & SIS (USA) & $=0.912$ & ICV (Poland) & $=6.630$ \\
\hline & ISI (Dubai, UAE & $=0.829$ & РИНЦ (Russia) & $=0.156$ & PIF (India) & $=1.940$ \\
\hline & GIF (Australia) & $=0.564$ & ESJI (KZ) & $=8.716$ & IBI (India) & $=4.260$ \\
\hline & JIF & $=1.500$ & SJIF (Morocco) & $=5.667$ & OAJI (USA) & $=0.350$ \\
\hline
\end{tabular}

цехового производства определялось консервативностью техники изготовления, но и в тот период муниципальные власти жестко проверяли качество изделий, равно как и способности кандидата в производители, действовало официальное положение, одобренное властью города или страны. Сельхозпродукция контролировалась самими потребителями.

Промышленная революция упростила процесс производства, создала условия массового производства. Потребовались адекватные меры контроля качества. По мере выравнивания социальной архитектоники и большей доступности к ассортименту товаров, менялись представления о качестве в направлении его качественности - качественных составляющих. Одновременно формировалась возможность фальсификации качества. Дальше и де-факто и де-юре, оставался всего шаг до подмены брендовых качеств. Переход за границу меры открывает дорогу правовым нарушениям и нравственному кризису, вплоть до беспредела.

Тенденции в толковании качества и отношении к качеству, сложившиеся в экономике массового производства, были неизбежными? Нет, они порождались новым характером производства, отражали этот характер и в известной степени являлись объективным отражением, но, кроме предмета, отражаемого сознанием, существует ракурс отражения, обусловленный позицией сознания отражающего субъекта, его интересами в качестве участника процессов, происходящих в объективной реальности.

Сама объективная реальность, по определению, располагается вне и не зависимо от сознания. Субъективируется ее отражение, что, в общем, выглядит в согласии с теорией отражения. Однако допускает, в частном порядке, и субъективное искажение - непроизвольное - по недопониманию, и сознательное с целью получения временного выигрыша. Конкуренция всегда борьба, к сожалению, борьба не всегда ведется по правилам.

Качество было и остается предметом манипуляции в интересах тех, кто управляет рынком. Консенсус о качестве создателя, производителя, продавца и потребителя - самая сладкая сказка. Согласие достижимо между творцом, потребителем и производителем. В данной «троице» воплощен субъектный механизм разрешения проблемы отчуждения. Творец создатель продукта находит удовлетворение в производстве и потреблении. Он реализует в них свою человеческую силу. Производитель заинтересован в устойчивых отношениях с творцом и потребителем. Потребитель удовлетворен качеством и соразмерностью цены. «Акции» и «sale» его не путают и не обманывают.[9]

На пути к консенсусу встает продавец, тот субъект отношений, который, по существу, к качеству товара не имеет никакого отношения, но именно он - ключевая фигура в рыночном хозяйстве. Мы у него приобретаем все необходимое. Он - монополист и как таковой диктует условия отношений через ценовой интерес и размер прибыли. В Новосибирске за двадцать лет не появилось ни одного брендового предприятия легкой промышленности, напротив, объявилась масса торговых брендов. Торговые ряды множатся, а потребителя уверяют, что производство товара нерентабельно. Культуру организации торговли подменяют понятием «качество продажи». Культура торговли измеряется ассортиментом, ценовой и физической доступностью товара, качественным консультативным сопровождением, отсутствием очередей, соблюдением санитарно-гигиенических норм, внешним видом и поведением персонала, сервисным обслуживанием. «Качество торговли» определяется соразмерностью цены и качества товара, соответствием продаваемого товара его сертификату, демонстрацией товара. Размер прибыли продавца не должен превышать величину прибыли производителя. Обоим нужно не ждать повышения покупательской активности только за счет увеличения зарплат потребителей, а создавать режим наибольшего благоприятствования для покупателя (не вступая в сговор с еще одним хищником рынка банками).

Размер инфляции - необходимый, но не достаточный показатель состояния качества жизни. Правительство за основной ориентир взяло снижение инфляции. Показатель на самом деле социально-экономически значимый, свидетельствует о культуре рынка и опосредованно о состоянии производства. Минус этого показателя- отсутствие в нем качества. Качество жизни определяется через количество потребляемой продукции в денежном выражении. Качественный состав остается постоянным и о качественности можно лишь домысливать, так как качественность размывает качество. Качественность обуви, одежды, круп, рыбы, овощей, фруктов в пределах общего названия весьма существенно разнится. Резерв манипулирования качеством значителен. Главное все же в понимании качества, не название, а системная характеристика продукта, отражающая ассортимент, его изменение и динамику пропорционального представительства составляющих совокупность товаров.

$$
\text { Качество представляет }
$$

систему существенных для товара свойств - это банально и общеизвестно, чем активно пользуются. 


\begin{tabular}{|c|c|c|c|c|c|c|}
\hline \multirow{4}{*}{ Impact Factor: } & ISRA (India) & $=3.117$ & SIS (USA) & $=0.912$ & ICV (Poland) & $=6.630$ \\
\hline & ISI (Dubai, UAE & $=0.829$ & РИНЦ (Russia) & $=0.156$ & PIF (India) & $=1.940$ \\
\hline & GIF (Australia) & $=0.564$ & ESJI (KZ) & $=8.716$ & IBI (India) & $=4.260$ \\
\hline & JIF & $=1.500$ & SJIF (Morocco) & $=5.667$ & OAJI (USA) & $=0.350$ \\
\hline
\end{tabular}

Подменяя свойства либо их системность в качественном продукте. Существенные свойства - те, которые не просто присущи товару, они обусловливают его функциональность. Подобные свойства, как правило, раскрываются в процессе «работы» товара по назначению, они скрыты от непрофессионального взгляда потребителя. В «чистом» виде рынок - посредник и к качеству изделий не должен иметь интереса. Задача рынка в теории организации товарного производства организация обмена между производителем и потребителем. Развитие рынка стимулирует наращивание производства в интересах потребителя в пределах инфраструктурного статуса рынка.

Монополизация производства привела к накоплению финансового капитала, автономизации последнего и контролю за рынком. В результате рынок из посредника превратился в ключевого субъекта, индикаторную функцию - показывать востребованность товаров - пытается подменить ролью организатора экономической деятельности в целом, что извращает систему экономики.

Экономику товарного производства создали производство продукта и потребность в массовом продукте. Системообразующим фактором здесь является производство товара в качестве продукта, необходимого для потребления другими, то есть процесс отчуждения потребления. При натуральном производстве качество продукта вряд ли было актуальной проблемой. Качество «растворялось» в консерватизме техники и технологии, традиционности ассортимента. Вопрос о качестве поднял потребитель, когда на ярмарке получил возможность сравнивать. Рынок, выросший из ярмарочных сходов, представительский статус постепенно обогатил рекламным бизнесом, взяв в управление отношения производителя и потребителя. Рычаги управления - финансовая политика, направления - основные - два: влияние на количество и качество.

Качество продукта обрело актуальность в товарном производстве. Стало ясно, что в понимании качества присутствуют чувственное и рациональное мышление (последнее в форме расчета). Субъективный фактор объективируется и фетишизируется. На объективные свойства товара рынок непосредственно (с помощью собственных механизмов) воздействовать не способен, зато на объективизацию субъективных представлений, очень даже может. Так манипуляция качеством сначала включалась в функции рынка, потом стала элементом экономической политики.

Здравая и здоровая экономическая политика призвана работать над совершенствованием качества в двух взаимосвязанных направлениях: технико-технологическом, достроенным жестким правовым блоком обеспечения, и социокультурном - оказывать всестороннюю поддержку становлению условий субъективного восприятия качества, блокировать негативный эффект рекламного воздействия, давно и основательно ставшего атрибутом рыночных спекуляций на значимости качества для покупателя. Наличие выбора и платежеспособных возможностей не служат основанием бесспорности качественного приобретения.

На существующем рынке цена и качество разведены даже на аукционах, славящихся тщательностью организационной культуры. Покупателя превращают в эксперта и эта гримаса рынка не столь плоха, как нелогична. Рынок заставляет потребителя развиваться в качестве личности, мы невольно стараемся больше узнать о предмете интереса, повышаем свою «покупательскую квалификацию». Термин не новый, им пользуются журналисты, но для них он проходной, вербальный номер, а для нас уже не новое сочетание расхожих слов, а важнейшее понятие, без которого современная теория качества не имеет системного целостного вида.

«Покупательская квалификация» включает, наряду с определенными знаниями, помогающими определить местоположение магазина, диапазон цен на товар, требует наличия основных сведений о производителе, качественных признаках товара, рыночной репутации производителя, традиций фирмы, масштабов деятельности. Сегодня на потребительском рынке наивный покупатель рискует сверх всякой позволяющей меры оказаться жертвой не только обмана, но и собственной беспечности, следовательно, без каких-либо прав на компенсацию.

Покупатель в России защищен формально. В реальной жизни приходится руководствоваться знаменитым правилом «спасение утопающих («покупающих») - дело рук самих утопающих, читай «покупающих». Повышение «покупательской квалификации», при наличии желания, для государства взаимовыгодное дело, активизирующее культурное национальное наследство и патриотическое настроение массового потребителя.

Мы умеем делать качественные изделия и вполне в состоянии вернуть себе «наш» рынок. Вопрос даже не в цене, проблема в потере контроля за потребительским (и не только потребительским, судя по сбоям в ракетной технике, эксплуатации авиатехники и т.п.) рынком. Нам объясняют: нужны экономические меры. Правильно, однако, это полуправда. Если нужны, то принимайте. У власти должна быть 


\begin{tabular}{|c|c|c|c|c|c|c|}
\hline \multirow{4}{*}{ Impact Factor: } & ISRA (India) & $=3.117$ & SIS (USA) & $=0.912$ & ICV (Poland) & $=6.630$ \\
\hline & ISI (Dubai, UAE & $=0.829$ & РИНЦ (Russia & $=0.156$ & PIF (India) & $=1.940$ \\
\hline & GIF (Australia) & $=0.564$ & ESJI (KZ) & $=8.716$ & IBI (India) & $=4.260$ \\
\hline & JIF & $=1.500$ & SJIF (Morocco & $=5.667$ & OAJI (USA) & $=0.350$ \\
\hline
\end{tabular}

власть не номинальная. Пришло время понять, что экономика всегда была политикой, экономическая теория - политической экономией.

Экономическое движение есть самодвижение, но оно не в вакууме происходит. Экономика - основа общественного движения. Общество обеспечивает условия экономического движения, и государство вправе энергично включаться в механизмы экономического самодвижения, направляя развитие экономики в интересах общества.

Государство вяло защищает законные интересы национального производителя, даже тогда, когда товар - продукт межнациональной интеграции. Нет политической агрессивности, политика тащится в обозе экономики вместо то, чтобы опережать ее развитие на базе объективных социально-экономических тенденций.

Время для политического действия - не решений - самое благоприятное. Дурман девяностых и нулевых как будто пошел на спад. Возвращается осознание качественного преимущества многих советских продуктов легкой и пищевой промышленности. Наблюдается оживление в потребкооперации, что способно стимулировать производство сельхозпродуктов на селе. Растет недоверие к потребительскому импорту, в том числе и по причине его массового китайского производства. Стабилизируются миграционные потоки.

Отечественным производителям нужна «внятная» экономическая политика. Под «внятностью» они понимают: ясность, последовательность, гарантийное сопровождение, позволяющее отсечь многоликий произвол административных органов и «блюстителей» порядка. За качество отвечают все. И те, кто производит, и те, кто призван обеспечивать права производителей. Таможенный Союз зажег зеленый свет на пути национальных товаров на рынке стран Договора. Тем самым создана равновесная реальная рыночная конкуренция, позволяющая оценивать натуральное, а не рекламное качество. Кстати, замечательная тема исследования - «качество реальное и «рекламное», т.е. создаваемое рекламой.

Не менее актуально, с нашей точки зрения, проанализировать проблему качества в системе координат национального менталитета и межнациональной интеграции. Интеграция сознательно подменяется глобализацией, несмотря на очевидность в различии этих явлений. Обе тенденции объективны и характерны для новейшей истории.

Интеграция -

межнациональное взаимопроникновение различных видов деятельности социально - экономического и культурно-гуманитарного масштаба. Она может иметь межнациональный размер, пример «Союзное государство (РФ и РБ); локальный Таможенный Союз; региональный (Шанхайская организация, ЕЭС). Глобализация указывает на всемирный масштаб явления. К числу глобальных проблем относятся те, которые возникли как следствие общих, но не обязательно интеграционных, процессов, и требуют консолидированного решения.

Глобальные проблемы, в отличие от проблем, связанных с интеграцией, актуальны потенциально, носят стратегический смысл. К примеру, как защитить жизнь на Земле от крупных метеоритов. Когда время наступления события отложено, но само оно сверхактуально по значимости, то в образовавшийся зазор активно устремляются спекулянты, в том числе финансовые олигархи, пытаясь извлечь прибыть из неопределенности.

Качество связано с глобализацией, но практически не так актуально. С интеграцией же качество связано самым непосредственным образом.

Рассмотрим проблему «качества потребительского товара» в системе координат «национальное» и «межнациональное». Прежде всего, надо найти ответ на вопрос: способна ли интеграция вытеснить национальную составляющую качества?

Интеграционные процессы строятся на стандартизации и единых метрологических характеристиках производства, что соответствует объективной реальности. Технический прогресс опирается на науку, научные знания императивны в части нормативности. Однако бытие общего не самодостаточно. Общие требования реализуются через особенное развитие, обусловленное конкретностью обстоятельств действия. Иными словами, как бы стандартизировано производство товара не было, все равно в нем проявится своеобразие условий производства.

Конкретность условий - региональных, национальных имманентно присутствует в сырье, климате, традициях, культуре сознания исполнителей. И во всем этом сила производства, определяющая нюансы качества товара, создающие особый к нему интерес потребителя. Чай выращивают в наше время по всему миру, но уникальность чайных плантаций в Шри-Ланке, национального отношения к чаю, обеспечили качеству цейлонского продукта лидирующие позиции. То же самое можно сказать о кенийском кофе, болгарском и чилийском перце, французских коньяках и шампанском, украинском сале, баварском и голландском пиве, шотландских виски, российском льне, египетском хлопке, китайском шелке, аргентинской коже, греческом оливковом масле и многом еще. 


\begin{tabular}{llllll} 
& ISRA (India) $=3.117$ & SIS (USA) $=\mathbf{0 . 9 1 2}$ & ICV (Poland) & $=\mathbf{6 . 6 3 0}$ \\
Impact Factor: & ISI (Dubai, UAE) $=\mathbf{0 . 8 2 9}$ & PUHЦ (Russia) $=\mathbf{0 . 1 5 6}$ & PIF (India) & $=\mathbf{1 . 9 4 0}$ \\
& GIF (Australia) $=\mathbf{0 . 5 6 4}$ & ESJI (KZ) $=\mathbf{8 . 7 1 6}$ & IBI (India) & $=\mathbf{4 . 2 6 0}$ \\
& JIF & $=\mathbf{1 . 5 0 0}$ & SJIF (Morocco) $=\mathbf{5 . 6 6 7}$ & OAJI (USA) & $\mathbf{0 . 3 5 0}$ \\
\hline
\end{tabular}

Конкретностью среды следует дорожить и обеспечивать преференции ее воспроизводства. В основополагающих договорах, регулирующих отношения в Единой Европе, четко прописан приоритет национальных традиций.

Таможенный Союз закрепляет межнациональное разделение труда, выстроенное в XX столетии, способствует выражению объективных и субъективных сторон развития производства, взаимно обогащает рынок, облегчая доступ к нему производителей. Но все это - теория. Теория же перерастает в разумную практику не только потому, что она правильная. Практикой теорию делает деятельность, причем, чтобы получить искомый результат, деятельность должна быть системной и последовательной.[10]

Интерес к качеству товара, теоретически должен начинаться не в производстве. Его исходная позиция на нормализованном рынке, точнее на встрече производителя и покупателя. Нормальный рынок - индикатор качества товара. Спрос тянет за собою производственную цепочку. Но не стихийный спрос брошенных на произвол судьбы покупателей. Спрос - состояние сознания, обусловленное покупательской способностью, однако не сводимое только к количеству денег, тем более, когда кредитование всячески стимулируется банками. Спрос, отданный на откуп посредникам, лоббистам, спекулянтам - смертельная болезнь для национального производителя России. Спрос следует брать под контроль и формировать, покупателя нужно воспитывать. Воспитание потребителя стоит немало. Но оно этого стоит, если смотреть в будущее.

Рыночный либерализм соответствовал расцвету экономики массового производства первого типа, ориентированной на обеспечение свободного доступа и выбора товаров. Подобное производство воспринимает потребителя как абстрактного субъекта отношения в системе «производитель - $\quad$ продавец - $\quad$ покупатель». Продавцу отводится роль активного посредника, но не более того. Он культурно обеспечивает место встречи производителя с потребителем. Система же должна быть функционально активной, что предполагает не присутствие образующих ее компонентов, а их соучастие. Совершенство системы определяется не эстетичностьюпризнаком конструкции. Оно проявляется в максимальной активизации возможностей того, системой отношений чего она выступает. Совершенство конструкции системы - в предельной реализации потенциала отношений, создающих системность.

Покупатель совершенен как субъект системного взаимодействия своей покупательской подготовкой. Он совершенен не размером платежной способности, его соучастие определяется знанием товарно-экономической ситуации. Потребитель - не объект приложения действий продавца и производителя. Потребитель - субъект рынка и в его (и других субъектов тоже) интересах быть информированным не рекламным сообществом, а профессиональными источниками. Качество товара начинается в сознании потребителя. Навязывать представление о качестве - плохо для всех законных субъектов экономических отношений. Его нужно воспитывать опять-таки всеми: производителем, продавцом, самим покупателем и институтами гражданского общества, если государство пассивно.

Переход к массовому производству второго типа - «умной», «рачительной» экономике активирует системные отношения. В новом свете предстает функция рынка. Вместе с производителем, продавец ориентируется на знание потребительских вкусов. К совершенству системы остается сделать всего один, однако не простой, шаг- всем миром взяться за формирование потребительской культуры.

Обвинение нынешнего поколения в потребительском отношении к жизни не совсем справедливо. Потребление - конечная цель производства. Беда - $\quad$ в отсутствии потребительской культуры массового потребителя, беда действительно социокультурного размера. Еще одно последствие финансирования культурного прогресса. Почему одна власть сменяет другую, а культура по-прежнему у власти последняя в очереди на политическую актуальность? Время понять, что не только наука превратилась в непосредственную производительную силу. Культура - также фактор развития производства, причем фактор многогранный и весьма эффективный.

Реформы Ельцина-Гайдара должны были с неизбежностью разрушить в первую очередь машиностроение и легкую промышленность. Ельцин теоретической подготовкой не отличался. Гайдар же обязан был отчетливо сознавать, что большинство наших достижений в данных отраслях производства - ВПК и космическую технику в расчет не берем - являлись «домашними» успехами. Здесь мы явно отставали от конкурентов, на общий рынок с которыми нацелились демократы.

У нас не было того, что имели поляки или китайцы. Польские интересы активно лоббировали в Европе, США и Канаде, да и масштабы польских преобразований не сопоставимы с российскими. В Китае после культурной революции можно было минимизировать расходы на зарплату основной массы трудового населения. К тому же китайские лидеры оказались явно умнее, честнее и 


\begin{tabular}{|c|c|c|c|c|c|c|}
\hline \multirow{4}{*}{ Impact Factor: } & ISRA (India) & $=3.117$ & SIS (USA) & $=0.912$ & ICV (Poland) & $=6.630$ \\
\hline & ISI (Dubai, UAE & $=0.829$ & РИНЦ (Russia) & $=0.156$ & PIF (India) & $=1.940$ \\
\hline & GIF (Australia) & $=0.564$ & ESJI (KZ) & $=8.716$ & IBI (India) & $=4.260$ \\
\hline & JIF & $=1.500$ & SJIF (Morocco) & $=5.667$ & OAJI (USA) & $=0.350$ \\
\hline
\end{tabular}

патриотичнее. Они руководствовались идеями Дэн Сяопина о параллельности развития социалистических завоеваний и экономических реконструкций, по сути дела модернизировали ленинский план НЭП. Опыт нарастания индустриальной и финансовой мощи КНР в последующие десятилетия доказал, что экономически слаб не социализм, а управляющие социалистическим строительством.

Реформы редко бывают плодотворными, но, тем не менее, они важны. Действительные, то есть научно обоснованные реформы, не могут быть продолжительными. Они эффективны именно благодаря временному лимиту. Время судит реформы и реформаторов. Псевдореформы, как правило, принимают перманентное выражение, обрастают ссылками на мировую конъюнктуру, климатические аномалии и т.п. Что и случилось в нашем отечестве. Однако одна беда не приходит. Реформаторы должны были объяснить народу, почему испытывают его терпение. Прием они выбрали так же архивныйпереложить с больной головы на здоровую.

В 2000-е годы активно множились мифы о дураках, дорогах, пьянстве, плохом образовании, застое в науке, инженерно-техническом творчестве, управленческой слабости, безыдейности. Смысл мифотворчества был прост: как же тяжело управлять таким народом. Петр I, получив в наследство отсталую Русь, не страдал. Он действовал и разделил историю на допетровскую Русь и петровскую Россию, заставив считаться с ее интересами весь мир.

Отечественные мифы плодятся и распространяются. Они завоевывают позиции и в легкой промышленности, что опасно политически, ибо угрожают активизации мер по интеграции экономик, культур, стратегических интересов России и соседних государств. Подобные сказки дискредитируют россиян в глазах тех, кто серьезно намерен с нами сотрудничать сейчас и в перспективе.

Остановимся на некоторых мифах, так или иначе связанных с настоящим и будущим отечественной легкой промышленности. Это важно проанализировать и в профессиональнообразовательном процессе.

Начнем с того, о чем говорят повсюду, с тезиса о том, что мы сидим на нефтяной и газовой игле, торговли углем, лесом и минеральным сырьем. Действительно, наши доходы от продажи сырья составляют почти 50 процентов. Показатель откровенно нежелательный. Тем не менее, можно было бы выстроить совершенную экономику, как это сделали Норвегия, Эмираты, Кувейт. Суть проблемы не в том, что Россия оказалась в зависимости от своих природных богатств, а в том, как используются доходы. Китай развивает производство, особенно транспорт, строительство, легкую промышленность. У нас же только в последнее время обратили внимание на тех, кто россиян обувает, одевает, изготавливает текстиль. Оказалось, что «бесперспективная» отрасль отзывчива. Общий объем рынка одежды, обуви, аксессуаров в 2012 году составил 2,8 трлн. рублей, а в прошедшем перевалил рубеж 3 трлн. Сделаны же всего-то первые шаги.

Еще один распространенный миф о неспособности конкурировать с аналогичным производством в КНР. Спора нет - низкая зарплата дает китайцам фору в борьбе за себестоимость. Но, китайцы вынуждены будут повышать зарплату, другие орграсходы у них уже оптимизированы, погоня за количеством сопровождается утратой качественности китайских товаров, надежда на европейские брендовые заказы должна уменьшаться в связи с кризисной волатильностью и сокращением внешних инвестиций.

Европе и США нужен Китай, однако им нужен Китай, работающий на них. Китайцы наверняка думают иначе. Противоречия станут нарастать по мере усиления Китая. Китай никто развивать в мирового лидера, кроме китайцев, не хочет. Темпы роста экономики КНР снизились.

Есть и еще одно обстоятельство, сдерживающее развитие производства товаров народного потребления в Китае - отдаленность от потребителя. Сейчас транспортные услуги растут опережающими темпами, ибо высоки цены на энергоносители и в обозримой перспективе снижаться не собираются. Когда американцы искусственно обесценили нефть с целью подорвать экономику СССР, они вряд ли думали, что их политика настолько поднимет производство в Китае. Китайцы умело воспользовались борьбой сверхдержав. А 1980-е, 1990-е, 2000-е миновали. Вместе с ними изменилась политикоэкономическая ситуация в мире.

Какое-то время дешевая рабочая сила найдется в соседних с Китаем странах ЮгоВосточной Азии - Камбодже, Филиппинах, Малайзии, Таиланде, Лаосе, Вьетнаме, Индонезии, но в них нет китайской политической стабильности, гарантирующей сохранность капвложений. К тому же они морские страны, железнодорожное и автосообщение с ними затруднено неразвитостью железных дорог, их региональным масштабом. Морские пути небезопасны. Пираты XXI века вокруг Африки ведут себя по-хозяйски. Они понимают бесперспективность пытаться всех «купцов» конвоировать.

Присовокупим к рассуждениям тезис, не часто попадающий в поле зрения: низкая квалификация рабочей силы в регионе. 


\begin{tabular}{|c|c|c|c|c|c|c|}
\hline \multirow{4}{*}{ Impact Factor: } & ISRA (India) & $=3.117$ & SIS (USA) & $=0.912$ & ICV (Poland) & $=6.630$ \\
\hline & ISI (Dubai, UAE & $=0.829$ & РИНЦ (Russia) & $=0.156$ & PIF (India) & $=1.940$ \\
\hline & GIF (Australia) & $=0.564$ & ESJI (KZ) & $=8.716$ & IBI (India) & $=4.260$ \\
\hline & JIF & $=1.500$ & SJIF (Morocco) & $=5.667$ & OAJI (USA) & $=0.350$ \\
\hline
\end{tabular}

Поддерживать качество товаров сложного производства можно предельной механизацией и автоматизацией. Круг замыкается, так как нужны высококвалифицированные инженеры, техники. Они привыкли к определенному образу жизни и достойному вознаграждению за свой остро востребованный труд.

Издержки потянулись вверх и стали разочаровывать инвесторов. Прежде всего, их расстраивает логика бесперспективности продолжения движения по накатанной дороге. Сворачивать всегда нелегко, но приходится. Изменения реальных условий предполагают перемены в бизнес-планировании.

Возвращаются из дальних стран на родину и российские бизнесмены, ориентированные на производство товаров массового спроса: текстиля, обуви, одежды. Примеров не так много, как хотелось бы, но они весомые и заразительные. Потянулись с производством поближе к землякам известные дизайнеры Кира Пластинина и Алена Ахмадулина. Пластинина выстроила производство одежды в Подмосковье, Ахмадулина открыла фабрику в Северной столице. Владелец 48 фабрик по пошиву одежды и фирменного бренда «Глория Джинс» В. Мельников закрыл фабрики в Китае, осел в России и в Украине. Работает пять лет и в основном своим решением удовлетворен.[11]

Эксперты сходятся во мнении о реальности российским производителям встроиться между европейскими фирмами и китайским ширпотребом, спрос на который вынужденный. Статистика подтверждает - россияне во второй половине 2013 года сократили расходы на покупки в данном секторе рынка. Нам по силам конкурировать с турками и восточными европейцами, заметно просевшими в Единой Европе.

Замглавы Минпромторга РФ В. Евтухов констатировал, что наши компании на равных конкурируют на рынке масс маркетинга в секторах мужских костюмов, домашнего текстиля, постельного белья, обуви, трикотажа, готовой кожи и нетканых материалов. Нельзя не согласиться и с мнением чиновника о наличии в стране отличных дизайнеров, достижениях высокой российской моды.

Вступление в ВТО осложнило отношение государства к производству. По существу, оно отделено от процесса производства. Участие власти и бюджета ограничено опосредованным влиянием путем создания благоприятных и стимулирующих развитие производства условий, таких как госзаказы, таможенные пошлины, налоговые льготы, совершенствование сырьевой базы. И все же проблемы отношения власти, ответственной за благосостояние народа и производства, в котором занят народ и которое его кормит, обувает, одевает, обустраивает, заключены не в ограничениях, накладываемых членством в ВТО. Суть новой ситуации в организации деятельности самой власти.

Условия вхождения в ВТО обнажили социально-экономические масштабы пороков российских управленцев - коррупционной составляющей, низких значений профессиональной культуры. Порочна и сама идеологическая установка на отделение управленческой профессии от специфики объекта управления. «Чистый» управленец возвращает нас к установке средневековых схоластов реалистов.

Есть научная теория управления, сосредоточившая в себе продукты рефлексии над управленческим опытом. Как всякая теория она не является рабочим инструментом управленца. В ней управленец ищет направления и возможные приемы деятельности. Точно также в демонстрации высокой моды пытается схватить значимые идеи бизнесмен, разбирающийся в моде, экономике и общественном настроении барометре рынка. Теория работает только в качестве адаптированного приложения к конкретности объекта управления. Кто не знает такой конкретности, того спасет исключительно командный способ управления, подчиняющий управленческую теорию производственной реальности.

«Чистый» управленец - заложник финансов. Для него производство - комбинация денежных потоков, а не организация человеческого воспроизводства в рамках национального развития. Он оторван от дела и чужой, как правило, в команде - назначенный командир из «параллельного» дела.

История XXI века с топ менеджерами наглядно показывает, насколько они значимы. Bce топовые компании первыми проявляют признаки кризисов и последними из кризиса выходят, несмотря на господдержку. Просто эти компании «национально-образующие», лицо государства. Государство заинтересованно в том, чтобы лицо не морщилось прежде времени. Большинство «вип-персон» из менеджеров на этом спекулирует. Юдашкин, выполнявший госзаказ на разработку и пошив формы для ВС, справедливо возмущался тем, что с его моделями и указаниями сотворила компания «чистых» управленцев во главе с Сердюковым, разместившая изготовление вещей в Китае и изменившая тех. условия.

«Чистый» управленец повсюду тянется не к производству, а к финансам. Ему нужна быстрая отдача. Быстрой отдачей управляет рынок. Реальное производство не может скакать, оно движется плавно. 


\begin{tabular}{|c|c|c|c|c|c|c|}
\hline \multirow{4}{*}{ Impact Factor: } & ISRA (India) & $=3.117$ & SIS (USA) & $=0.912$ & ICV (Poland) & $=6.630$ \\
\hline & ISI (Dubai, UAE & $=0.829$ & РИНЦ (Russia & $=0.156$ & PIF (India) & $=1.940$ \\
\hline & GIF (Australia) & $=0.564$ & ESJI (KZ) & $=8.716$ & IBI (India) & $=4.260$ \\
\hline & JIF & $=1.500$ & SJIF (Morocco & $=5.667$ & OAJI (USA) & $=0.350$ \\
\hline
\end{tabular}

Нормальное развитие производства требует, наряду с умными решениями, жесткий контроль за неукоснительным исполнением предписаний. Всем известно, на каком рубеже и каким образом тормозятся политические инициативы. Ясно и то, что управление механизмом управления чиновниками всех уровней - входит в прерогативу правительства. Именно в том, как оно управляет управленцами, по-видимому, надо искать критерий качества деятельности правительства. И называется эта миссия очень просто - политической волей. Без должной обоснованной - меры воли порядка не будет.

Миротворцы любят прятаться за цифры, подавая их так, как им выгодно. Цифры, особенно большого объема впечатляют непросвещенных. Скрывать за ними расклад дела удобно и выгодно - можно в глазах публики предстать победителем.

Правительство разработало и приняло «Стратегию развития легкой промышленности России на период до 2020 года». Через «семилетку» совокупная доля отечественных товаров легкой промышленности на внутреннем рынке должна быть равна совокупному импорту. Планируется достижение стратегического перелома в интересах отечественного производителя.

На рынке своя война, отличная от обычной, похожая на «холодную». Здесь доводить дело до полного уничтожения противника нельзя. Щука в озере не дает застояться остальным обитателям, заставляет их двигаться в реальном времени пространстве. В начале 1990-х годов десятки миллионов россиян с вожделением глядели на богатство ассортимента заграничного производства. Двадцать лет спустя разочарованные россияне ищут что-нибудь собственного изготовления, сообразив, что подлинное качество не способно быть безразмерно пестрым.

Погоня за богатством ассортимента мало что общего имеет с нормальными интересами массового потребителя. Хорошего много не бывает, потому что быть не может. За границами меры настоящего, объективно данное качество, уступает место рекламному. «Подобное»понятие математическое, формализующее качество предметов. «Подобное» в реальности, как правило, подменяет подлинное качество. Почему? Потому что подобное нивелирует качество товара.

Качество тождественно оригинальности, самому себе. Вино одного и того же производителя, изготовленное по многовековому рецепту, различается в цене в зависимости от года сбора урожая винограда. Ассортимент оправдан тогда, когда в нем реализуется разнообразие оригинального качества и качественных состояний.
Вытесняя импорт с рынка, нужно быть готовым развернуть дисперсию качеств собственной продукции. А здесь наш социалистический опыт не велик и его необходимо наращивать всеми доступными мерами. В частности, предлагается увеличение в общем объеме до 46 процентов доли инновационной продукции.

Двигаться вперед заставляет прогресс, но вряд ли есть смысл спешить. В массовом сознании есть законы. Оно консервативно. Умной экономику делают не менеджеры, умной она станет, обретя соответствие устойчивым интересам общественной востребованности. Надо не за новациями гоняться, - изучать здравый смысл в народном сознании.

Китайцы не любят перемен в политике. Россияне боятся перемен в ассортименте. Сравнивая рекламируемые преимущества новейших товаров с настоящими материалами и свойствами достаточно забытых вещей, они понимают траекторию качественности: будет хуже и дороже. 1990-е годы чему-то нас научили, по крайней мере, эйфория ассортимента прошла. Потребителю присуще стремление к новому, но опытный потребитель избирательно относится к обновлению, сообразуя витринное разнообразие со вкусом, выработанным опытом потребления.

Увеличение экспорта за планируемое время в 3 раза и доведение до 3 - 5 млрд долларов весьма оптимистичное обязательство. Поэтому такой непривычный для статистики разброс значений. Что же касается задачи на 10 процентов сократить теневое производство и нелегальный ввоз, то здесь все выглядит реально, отражает требования лоббистов. Логика интересная: внешний рынок для нас - проблема решаемая, то же, что у нас внутри, - нам существенно изменить не по силам.

Нехотя чиновники борются с нелегалами. Очень уж большие деньги крутятся в теневом бизнесе, столько на экспорте не заработаешь. Между прочим, наш «конек» в легкой промышленности, на середину 2010-х, не освоение чужого пространства, а строительство собственного рынка, иначе переходный период экономики от социализма к капитализму затянется надолго, и наш капитализм будет образца европейского начала XIX века.

Среди специалистов по мировой экономике бытует мнение о начале массового исхода капитала из Китая. В оценках статистических данных следует проявлять больше сдержанности. Мировые финансовые потоки словно «капризные» реки разливаются непредсказуемо, инвестиции переливаются разнонаправлено и волнообразно. Даже значительное время наблюдения не служит достаточным основанием для однозначного заключения. Во всяком случае, 


\begin{tabular}{|c|c|c|c|c|c|c|}
\hline \multirow{4}{*}{ Impact Factor: } & ISRA (India) & $=3.117$ & SIS (USA) & $=0.912$ & ICV (Poland) & $=6.630$ \\
\hline & ISI (Dubai, UAE & $=0.829$ & РИНЦ (Russia) & $=0.156$ & PIF (India) & $=1.940$ \\
\hline & GIF (Australia) & $=0.564$ & ESJI (KZ) & $=8.716$ & IBI (India) & $=4.260$ \\
\hline & JIF & $=1.500$ & SJIF (Morocco) & $=5.667$ & OAJI (USA) & $=0.350$ \\
\hline
\end{tabular}

Китай продолжит наращивать свое производство. Отток финансов и свертывание производства их не напугает. Китай в недавнем прошлом закалился, развиваясь по формуле Мао «опираться на собственные силы». Расположиться на китайском рынке нам можно, создавая совместные предприятия. Такую инициативу китайцы поддержат. Проще продвигать экспорт в соседние страны, предлагая более дешевые качественные товары по меньшим ценам. В молодых странах, ассоциированных в Европейское сообщество, население почувствовало ценовой прессинг и учится считать евро.

Триста лет назад Петр I проложил торговый путь в Европу, обеспечив отечественным купцам движение на Запад. Вплоть до советского периода, Россия оставалась поставщиком европейским партнерам сельскохозяйственного и природного сырья. На нашем сырье работала европейская легкая промышленность, разумеется, не только на нем, но отечественный продукт слыл на Западе качественным, пользовался устойчивым спросом. В памяти европейцев сохранилась на генетическом уровне история экономических отношений с Россией. Надо активировать память. В.В. Путин прав, поручив всесторонне заняться совершенствованием имиджа страны среди иностранцев.

Часто успехи Китая в науке, технике, привлечении инвесторов связывают с гигантских размеров диаспорой во всех частях света. Бывших россиян естественно меньше. Тем не менее, их много и они тоже разбросаны судьбой по всему Свету. Большая часть эмигрантов дорожит исторической родиной и наверняка не против помочь, в меру сил, созданию доверия и интереса к российским производителям.

Человечество, к счастью, не перестало удивляться. Любопытство тянет к новому, необычному, хочется хорошего, нужного, красивого и недорогого. Простая доступность товара осталась критерием приобретения в совсем уже бедных уголках Земли, у населения, находящегося ниже черты бедности. Все остальные научены «разнообразием» дешевых, неизвестно где и как изготовленных товаров [12].

Рекламная броскость внешнего вида и надоедливая реклама, уверяющая как они прекрасны, уводят покупателя в недавнее прошлое, которое обернулось полным разочарованием и потерей уплаченных денег. Китайские власти еще в 1980-е наказывали вплоть до казни за поддельные товары, справедливо считая, что спекуляция на национальном авторитете подрывает статус державы. Не наше дело искать истинные мотивы либерализации государственного отношения к производству ширпотреба, однако абсолютно ясно, что к началу третьего тысячелетия репутация Китая как страны, некогда производившей качественные товары массового спроса, достигла критических значений.

История - лучший из учителей. Извлекая уроки из исторического опыта и корректируя деятельность в реальном времени, много можно добиться. Ни в коем случае нельзя терять контроль за качеством товаров, ничто не может быть оправданием подобной политики. Массовость и разнообразие можно совместить с качественностью. Нужна новизна впечатления - от вида, материала, возможностей изделия.

Обольщатьс благоприятными предпосылками перспективы освоения новых рынков и укрепления позиций на существующих не следует. Предпосылки - это всего лишь реальные возможности. Возможности «ждут» деятельности трансформирующей их в действительную реальность. К сожалению, деятельность не только превращает один уровень реальности в другой. Она пересекает в себе различные интересы. Именно разнонаправленность интересов является регулирующим фактором движения к экономической цели.

Конкуренция за внешний рынок не ограничена внешним противоборством субъектов, экономических интересов. В экономической политике действуют «пятые колонны», представляющие и энергично защищающие цели противников. Они обрабатывают затраченные на свои действия финансы. Такова мировая практика, поэтому столь актуально благие намерения сочетать с волей и практической энергией. Выживает сильнейший. Сильнейшим же в борьбе за рынок бывает тот, кто умело пользуется сложившейся конъюнктурой и не экономит на продвижении товара, помня, сколько платит скупой.

Многое, как показывает зарубежная практика, определяется политической волей. Государство действует в рамках международных отношений, но у него всегда есть легальные рычаги управления экономическими процессами. Гособоронзаказ позволил довести долю продукции отечественных предприятий легпрома до $70 \%$, оставив в неведении тех, кто логично вопрошает: почему не 100? Вопрос ведь не риторический.

Массовый

технологическому прогрессу, снижает безработицу в сложных регионах, включает резервы профессионального образования. Если не хватало производственных мощностей, можно было и не спешить с переходом. Сначала подготовить производство. Время-то не военное. А так треть производства разместили у конкурентов, осложнив условия развития отрасли. Скачок от старых 30 \% к новым 70 - 


\begin{tabular}{|c|c|c|c|c|c|c|}
\hline \multirow{4}{*}{ Impact Factor: } & ISRA (India) & $=3.117$ & SIS (USA) & $=0.912$ & ICV (Poland) & $=6.630$ \\
\hline & ISI (Dubai, UAE & $=0.829$ & РИНЦ (Russia & $=0.156$ & PIF (India) & $=1.940$ \\
\hline & GIF (Australia) & $=0.564$ & ESJI (KZ) & $=8.716$ & IBI (India) & $=4.260$ \\
\hline & JIF & $=1.500$ & SJIF (Morocco & $=5.667$ & OAJI (USA) & $=0.350$ \\
\hline
\end{tabular}

бесспорно шаг в правильном направлении, однако последовательности в движении нет, ибо «кормить» конкурента и надеяться на ускоренное завоевание зарубежного рынка не логично.

Рынок - сложная и неоднородная система. Системообразующий фактор рынка противоположность интересов продавца и покупателя. Один стремится продать товар и получить прибыль, другой - купить и сэкономить. Разрешение противоречия интересов заложено в соответствии цены качеству.

На пути покупателя, как в сказке, расставлены препятствия. Надо сбросить чары рекламного пиара, разобраться в признаках качества, так как рынок допускает практически неограниченную технологию обмана, к примеру, имитацию качества, быть в курсе реальных цен (с учетом того, что на рынке товар дешевле, чем в бутиках и супермаркетах - ниже издержки, нелегальная доставка и т.п.). Покупателя спасает искусство выбирать и мыслить в границах «здравого смысла». Здравый смысл - надежный «лоцман» в движении по рыночным порогам и отмелям, но и в нем есть искушение, когда предлагают нечто необычное, вызывающее значимые ассоциации.

Лен - традиционный товар российского экспорта. Изделия из льна или с добавлением льна популярны. Они гигиеничны, экологичны, приятны в чувственном восприятии, льняная ткань технологична, эстетична, не требует деликатного отношения, всесезонна.

Производство льна и льняной ткани резко упало из-за депрессии сельского хозяйства в годы «судьбоносных» реформ. Надо стимулировать крестьян. Лен выращивать и выделывать трудоемко. Без специальной техники не обойтись. При создании технических условий и экономическом стимулировании производителя наладить дело можно быстро. Российские умельцы догадались использовать лен в сочетании с крапивой. Крапива не нуждается в рекламе. По своим свойствам она вполне конкурентна льну. К тому же имеет авторитет сильного и стойкого антибактериального средства, стимулятора кровообращения, нейростимулятора. Изделия из смесовой ткани на ярмарках Сибири ушли на ура! Привезли же новинку из нечерноземного российского запада. Нет никаких сомнений, что западный потребитель с интересом отнесется к новинкам. И на Востоке они будут востребованы.[13]

Наше государство планирует организацию текстильных кластеров в нескольких районах. Вероятно, оно учтет и сельскохозяйственные особенности тех мест, где вырастут обещанные кластеры. Материалоемкое производство, организуемое в крупных размерах, должно быть максимально приближено к сырьевой базе. Тем более в условиях роста опережающими темпами тарифов на перевозки. Разделение производителя конечного продукта и производства необходимого сырья ложится удвоенной нагрузкой на производителя и на продавца. В итоге страдает потребитель на розничной продаже, что при неустойчивости развития экономики бумерангом вернется в производство. Почему на Западе проще нашего выходят из кризиса и депрессии? Ответ ищите на рынке. Нормально организованный рынок за три столетия существования капитализма автоматически реагирует на снижение покупательской платежеспособности. В тяжелые для экономики времена бизнесмены стараются заполучить деньги покупателя уменьшением ценовой нагрузки на его «кошелек». Практика уничтожения лишней массы товара для поддержания цены осталась в прошлом. Рынок стимулирует массовый доступ покупателей к продукции различными акциями. Производители придумывают как старое сделать дешевым новым. Взгляд на качество в такое время упрощается и теряет актуальность до очередного экономического подъема.

У нас на рынке ничего подобного нет. Невольно возникает вопрос: нам так же нужно настроиться на трехсотлетнее ожидание или есть другой путь? Для тех, кто включается в движение по ходу последнего, история дает шанс заметно ускориться. Надо мобилизоваться на целевую установку. Требуется опять-таки политическая воля. Самодвижение экономики делается основным механизмом на этапе развитой экономики и должным образом настроенного национального сознания.

Общественному сознанию нужна ясная, симпатичная цель и уверенность в том, что цель эта общая и плоды будут справедливо разделены. Одно общественное устройство мы уже строили, демреформы нас разорили. Вопрос: кто виноват? задавать перестали. Остался вопрос: что делать? Этот вопрос вечный и ответ на него нормальный человек ищет всегда, обращаясь к социальным институтам и политикам, управляющим социальным развитием.

Без энергичной сельскохозяйственной политики российский легпром не решит поставленных стратегических задач. В свою очередь, поднять сельхозпроизводство без научной поддержки в XXI веке немыслимо. Процесс усложняет реформирование российской науки. Следовательно, надеяться остается на то, что издержки не будут непомерными и время не бескрайним. И еще важно не растерять в неизбежной суете и финансовом дефиците позитивного опыта.[14]

Развал СССР лишил Россию хлопковой базы и поставил в зависимость от капризных 


\begin{tabular}{|c|c|c|c|c|c|c|}
\hline \multirow{4}{*}{ Impact Factor: } & ISRA (India) & $=3.117$ & SIS (USA) & $=0.912$ & ICV (Poland) & $=6.630$ \\
\hline & ISI (Dubai, UAE & $=0.829$ & РИНЦ (Russia) & $=0.156$ & PIF (India) & $=1.940$ \\
\hline & GIF (Australia) & $=0.564$ & ESJI (KZ) & $=8.716$ & IBI (India) & $=4.260$ \\
\hline & JIF & $=1.500$ & SJIF (Morocco) & $=5.667$ & OAJI (USA) & $=0.350$ \\
\hline
\end{tabular}

поставщиков с национальными амбициями. Но оказалось, что не растеряла страна способности «производить своих ньютонов». Политикам ученые - селекционеры противопоставили свои ультрасовременные разработки. Был создан скороспелый сорт хлопка, отличающийся от мировых эталонов большей устойчивостью к засухе - «АC-1». В 2012 году собрали первый урожай хлопка на территории Астраханской области, переработали и изготовили качественное хлопковое полотно.

Логика свидетельствует, что задача создать в стране собственную сырьевую базу для развития легпрома, должна быть приоритетной. Техническое и технологическое оснащение, подготовку кадров нужно осуществлять в контексте именно ее. Разумеется, все представленные действия взаимосвязаны. Базу придется строить и совершенствовать специалистам, без современной техники и технологий обеспечить производство сырьем не получится. Кластеры останутся благими мечтами без сбалансированной системы строительства того направления в экономике, которое кто-то в насмешку назвал «легкой» промышленностью. Легкую промышленность ждут тяжелые годы, но в России «тяжело» и «успешно» всегда были в одной упряжке.

\section{Заключение}

Ставить верные цели - это значит - уметь «правильно сформулировать результат».

Основные принциипь формирования и выбора своих ичелей:

1. Выбирайте такие цели, которые заслуживают их достижения.

2. Выбирайте такую цель, которой сможете достичь своими силами.

3. Формулируйте свою цель в утвердительных терминах.

4. Выражайте свою цель точно, в сенсорных категориях.

5. Соотносите свою цель с контекстом (ситуацией).

6. Трезво оценивайте последствия достижения своей цели.

Подсознание играет важную роль во всем, что мы делаем. Деловые и организационные методы достижения целей (формализованные) обычно опускают этот фактор. То же относится и к индивидуальным целям, выбранным логическим, систематическим путем, «левым полушарием».

Думать в утвердительной форме - это принции правильной формулировки результата.

Многие обычно сосредотачиваются на попытках избежать нежелательного вместо того, чтобы думать о желаемом и добиваться желаемого. У них формируется «агрессивнооборонительный», «отрицающий» характер вместо «утверждающего». «Отрицающий человек» переживает, в конце концов, тот сценарий, которого хотел бы избежать, ибо именно он закрепляется стратегически и реализуется. Можно назвать такую систему «избегания» осмотрительностью, реализмом, благоразумием и так далее. Наиболее действенно она проявляется при достижении внутренних целей, но когда дело касается осознаваемых целей «...?.», она нередко приводит к непостижимым на первый взгляд промахам. Потому первый принцип правильно сформулированного результата гласит: «Выражаю свою цель в утвердительных терминах». [15]

Содержание любого события зависит от рамки, в которой мы его воспринимаем.

Принципы

сбалансированного самообновления.

Возможно, мы начали понимать, что если мы хотим что-либо изменить, то начинать изменение надо с себя. И для того, чтобы изменить себя эффективно, мы, прежде всего, должны поменять свое восприятие.

Принципы НЛП предполагают учет всех четырех измерений. Это означает, что мы должны регулярно и последовательно развивать их самым разумным и сбалансированным образом. Расходование времени на самообновление требует от нас инициативы.

Эффективные навыки - хорошо усвоенные принципы и модели поведения. Чтобы что-то в своей жизни превратить в навык, необходимы три компонента: Знание, Умение, Желание.

Знание - это теоретическая парадигма, определяющая что делать и зачем. Умение определяет как делать. А желание - это мотивация - хочу делать.

Если однажды мы поверим, что отныне наше поведение зависит от наших решений, а не от окружающих условий, то самый первый навык, необходимый при начавшемся саморазвитии личности - это проактивность. Под проактивностью надо понимать, осмыслив ее как факт, что, инициируя происходящее, подчиняя чувства нашим ценностям, мы несем ответственность за свои действия (и, прежде всего, перед собой). Поведение проактивного человека есть продукт его собственного выбора, он не ищет «виноватых» за свои поступки и за их результаты. В этом случае он себя спрашивает, и в себе ищет ответ. Стивен Р. Кови полагает (рисунок 3), что для достижения личной победы (победы над собой) человеку как минимум нужно еще два навыка (рисунок 2) (кроме - «Будь проактивным» (1): это - «Начинай, представляя конечную цель» (2), и «Сначала делай то, что 


\begin{tabular}{|c|c|c|c|c|c|c|}
\hline \multirow{4}{*}{ Impact Factor: } & ISRA (India) & $=3.117$ & SIS (USA) & $=0.912$ & ICV (Poland) & $=6.630$ \\
\hline & ISI (Dubai, UAE & $=0.829$ & РИНЦ (Russia) & $=0.156$ & PIF (India) & $=1.940$ \\
\hline & GIF (Australia) & $=0.564$ & ESJI (KZ) & $=8.716$ & IBI (India) & $=4.260$ \\
\hline & JIF & $=1.500$ & SJIF (Morocco) & $=5.667$ & OAJI (USA) & $=0.350$ \\
\hline
\end{tabular}

необходимо делать сначала» (3).Если в значении цели в нашей деятельности мы уже достаточно четко определились, то с третьим навыком надо еще разобраться. В данном случае имеется в виду необходимость управлять своим временем, четко представляя степень важности и срочности тех дел, которые намечаем к исполнению. [15]

Вполне очевидно, что для овладения навыком «Сначала делай то, что необходимо делать сначала», не срочные, но весьма важные дела по поддержанию своего ресурса будем стараться делать в первую очередь, и именно в этом деле как раз и будем нарабатывать первый и второй навык.

По мере овладения первыми тремя навыками мы все больше приобретем независимость от внешних факторов и все больше открываем возможность закрепить личную победу, пробуя по-новому взаимодействовать с окружающим нас миром себе подобных, осознавая объективную взаимозависимость. Для этого нам понадобятся еще три навыка: «Думай в духе выиграл/выиграл» (4), «Сначала стремись понять, a потом быть понятым»(5),»Достигайте синергии»(6). Сотрудничество и доверие - и результат и условие для закрепления этих важных в общении и коллективной деятельности навыков. Седьмой навык (7) Стивен Р. Кови назвал «Затачивай пилу».

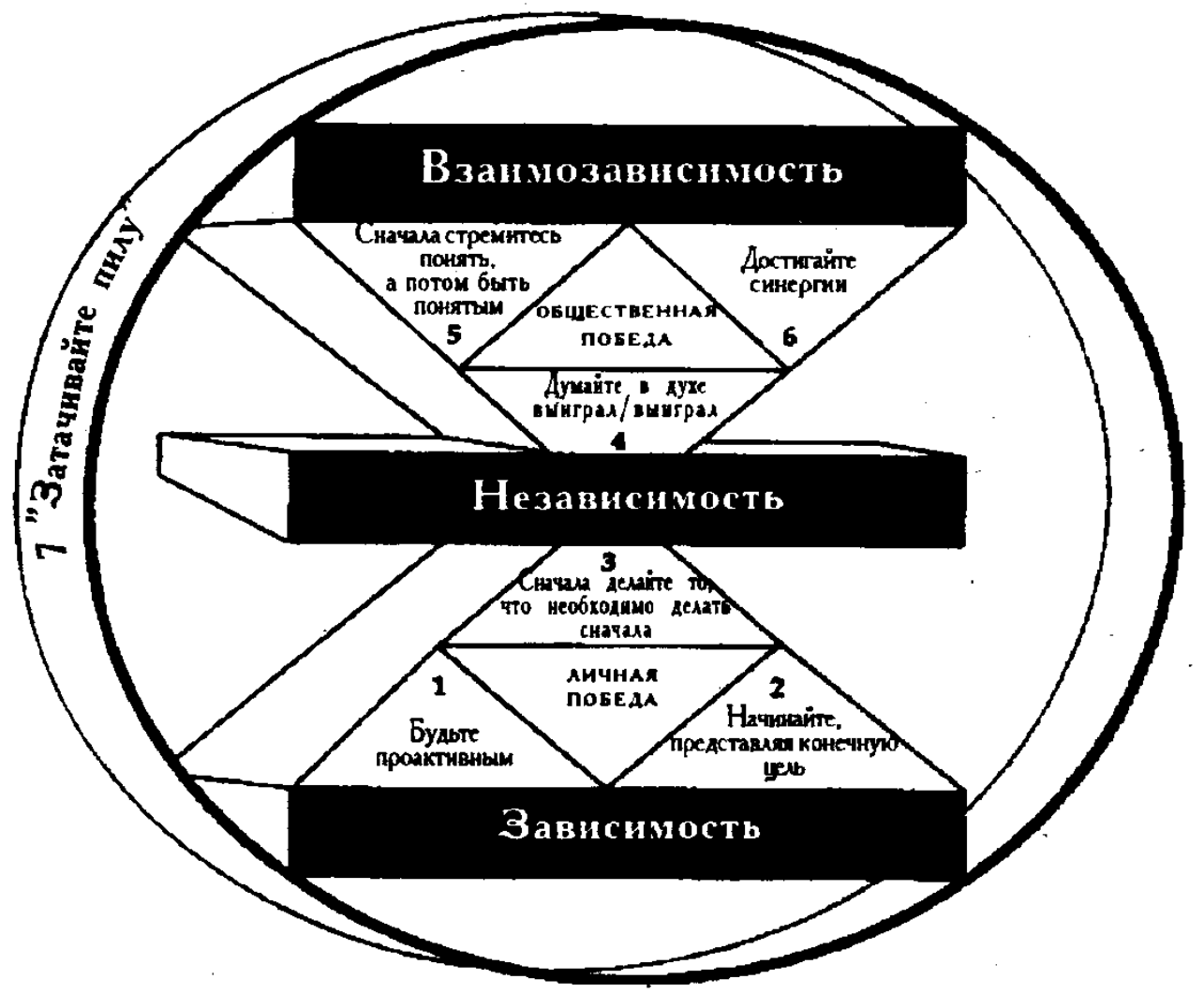

Рисунок 2 - Матрица управления временем:

1 - Будь проактивным, 2 - Начинай, представляя конечную цель 3 - Сначала делай то, что необходимо делать сначала 4 - Думайте в духе выйграл/выйграл 5 - Сначала стремитесь понять, а потом быть понятым 6 - Достигайте синергии 7 - «Затачивайте пилу»

Он не двусмысленно полагал, что мы можем рассчитывать на успех, на эффективность только тогда, когда будем делать постоянные усилия в деле формирования всех названных навыков, работая над всесторонним саморазвитием.

$B$ заключение надо признать, что, работая над своим обновлением в одиночку, сомнительно добиться успеха, даже имея все три составляющие для формирования необходимых навыков. Человек - существо социальное. Реально воспитание осуществляется только через поступок. В воспитании участвуют трое: кроме воспитуемого, еще должны быть воспитатель (делай как я) и ценитель (того чему учат и как получается). При самовоспитании - где взять еще двух недостающих? Выход только один 


\begin{tabular}{|c|c|c|c|c|c|c|}
\hline \multirow{4}{*}{ Impact Factor: } & ISRA (India) & $=3.117$ & SIS (USA) & $=0.912$ & ICV (Poland) & $=6.630$ \\
\hline & ISI (Dubai, UAE & $=0.829$ & РИНЦ (Russia & $=0.156$ & PIF (India) & $=1.940$ \\
\hline & GIF (Australia) & $=0.564$ & ESJI (KZ) & $=8.716$ & IBI (India) & $=4.260$ \\
\hline & JIF & $=1.500$ & SJIF (Morocco & $=5.667$ & OAJI (USA) & $=0.350$ \\
\hline
\end{tabular}

- найти образ, который бы был учителем, найти образ, который был бы ценителем. Мы не оговорились, а вы не ошиблись - именно ОБРАЗ или ОБРАЗЫ. Для этого могут подойти литературные герои, друзья, подруги, папы, мамы, бабушки, дедушки ... при вашем богатом воображении.

Вновь хочется вспомнить ещё одну русскую пословицу: «Что пока гром не грянет, мужик не перекрестится». Неужели обязательно наступить на грабли, получить ощутимый удар по лбу и закричать - «Фу, вспомнил название этого инструмента, что это грабли ». Смешно и грустно, и все же верим в здравый смысл, что истина дороже и правда восторжествует - мы сможем реанимировать эту самую легкую промышленность, что и подтвердили эксперты респонденты, проявив единодушие, по основным критериям оценки конкурентоспособности предприятий легкой промышленности, перечень которых, утвержденный по итогам совещания, приведены ниже. [3]

1. Правительству Российской Федерации:

a) предусмотреть при формировании проекта федерального бюджета на 2018 год и на плановый период 2019 и 2020 годов предоставление государственной поддержки предприятиям лёгкой промышленности ежегодно в объёмах не ниже уровня 2017 года.

Доклад - до 15 октября 2018 г. и до 15 января 2019 г.;

б) предусмотреть в рамках Государственной программы развития сельского хозяйства и регулирования рынков сельскохозяйственной продукции, сырья и продовольствия на 2013 2020 годы формирование подпрограммы, направленной на обеспечение лёгкой промышленности качественным сельскохозяйственным сырьём, а также реализацию противоэпизоотических мероприятий в целях ликвидации гиподерматоза крупного рогатого скота.

Срок - 1 февраля 2019 г.;

в) рассмотреть вопрос об установлении на федеральном уровне льгот по налогу на имущество организаций в отношении движимого имущества в целях стимулирования модернизации производства и обеспечить внесение соответствующих изменений в законодательство Российской Федерации;

г) принять меры по смягчению в рамках двусторонних международных соглашений с центральными ветеринарными органами зарубежных стран ветеринарных требований, предъявляемых к кожевенному сырью, ввозимому на территорию Российской Федерации;

д) определить реализацию тонкой и полутонкой шерсти, длинного льняного волокна перерабатывающим

предприятиям, расположенным на территории Российской Федерации, в качестве обязательного условия предоставления государственной поддержки сельскохозяйственным товаропроизводителям, осуществляющим производство данной продукции, и обеспечить внесение соответствующих изменений в нормативные правовые акты;

е) предусмотреть внесение в законодательство Российской Федерации изменений, направленных на развитие системы обеспечения прослеживаемости оборота товаров легкой промышленности.;

ж) рассмотреть вопрос о целесообразности введения утилизационного сбора в отношении обуви;

3) совместно с акционерным обществом «Российский экспортный центр» представить предложения по содействию развитию экспорта российской продукции легкой промышленности, в том числе путём компенсации затрат, связанных с выходом названной продукции на внешние рынки.

Радует, что предполагается их реализация в полном объёме и установленные сроки, понимая ответственность названных лиц и наличие у них мотивации действий.

Несмотря на принциипильные отличия выше рассмотренных этих концепицй, они, тем не менее, имеют нечто общее в своей основе, что отражает определенную общность в мотивации человека к действиям.

Названные концепции позволяют сделать вывод о том, что отсутствует какое-либо канонизированное учение, объясняющее то, что лежит в основе мотивации человека и чем определяется мотивация. Каждая из изложенных теорий имеет определенное принципиальное отличие. Так, например, в концепции Маслоу потребности расположены иерархически, и восхождение по ним идет снизу вверх. В теории Альдерфера также имеется определенная иерархия. Однако эта теория в качестве одного из важнейших положений имеет утверждение о том, что движение по иерархии может осуществляться как снизу вверх, так и обратно сверху вниз в том случае если не удовлетворяется потребность верхнего уровня. МакКлелланд ввел по отношению к рассматриваемым им потребностям идею их приобретения: и развития под влиянием обучения и жизненного опыта. При этом он принимает во внимание взаимоотношение отдельных групп потребностей, отойдя от рассмотрения изолированного влияния отдельных групп потребностей на поведение человека. В теории Герцберга потребности делятся на две большие группы: мотивирующие $u$ «здоровья». Тем самым указывается на то, что не все потребности постоянно оказывают мотивирующее влияние на человека, а 


\begin{tabular}{|c|c|c|c|c|c|c|}
\hline \multirow{4}{*}{ Impact Factor: } & ISRA (India) & $=3.117$ & SIS (USA) & $=0.912$ & ICV (Poland) & $=6.630$ \\
\hline & ISI (Dubai, UAE & $=0.829$ & РИНЦ (Russia & $=0.156$ & PIF (India) & $=1.940$ \\
\hline & GIF (Australia) & $=0.564$ & ESJI (KZ) & $=8.716$ & IBI (India) & $=4.260$ \\
\hline & JIF & $=1.500$ & SJIF (Morocco & $=5.667$ & OAJI (USA) & $=0.350$ \\
\hline
\end{tabular}

только те из них, которые приводят к развитию состояния удовлетворенности.

Как видно, каждая из теорий имеет что-то особенное, отличительное, что дало ей возможность получить широкое признание теоретиков и практиков и внести существенный вклад в разработку знаний о мотивации. Однако при этом, несмотря на принципиальные различия, все четыре вышеописанные теории имеют нечто общее, позволяющее установить определенные параллели между ними. Характерной особенностью всех четырех теорий является то, что они изучают потребности и дают классификацию потребностей, позволяющую делать некие выводы о механизме мотивации человека. Сравнивая классификации всех четырех теорий, можно отметить, что выделенные в различных теориях группы потребностей достаточно определенно соответствуют друг другу.[16]

В таблице 1 дано некое условное соответствие групп потребностей мотивации человека к действию, выделяемых в данных четырех концепциях.

Таблица 1 - Характеристика мотивации человека и действий, сформулированные в своих концепциях Маслоу, Альдерфера, МакКлелланда и Герцберга.

\begin{tabular}{|c|c|c|c|c|c|}
\hline ТЕОРИИ & \multicolumn{5}{|c|}{ ГРУППЫ ПОТРЕБНОСТЕЙ } \\
\hline $\begin{array}{l}\text { Теория } \\
\text { Маслоу }\end{array}$ & $\begin{array}{l}\text { Потребность } \\
\text { самовыражения }\end{array}$ & $\begin{array}{l}\text { Потребность } \\
\text { признания и } \\
\text { самоутверждения }\end{array}$ & \begin{tabular}{|l} 
Потребность \\
принадлежности \\
и причастности
\end{tabular} & $\begin{array}{l}\text { Потребность } \\
\text { безопасности }\end{array}$ & $\begin{array}{l}\text { Физиологические } \\
\text { потребности }\end{array}$ \\
\hline $\begin{array}{l}\text { Теория } \\
\text { Альдерфера }\end{array}$ & \multicolumn{2}{|c|}{ Потребность роста } & Потребность связи & \multicolumn{2}{|c|}{ Потребность существования } \\
\hline $\begin{array}{l}\text { Теория } \\
\text { МакКлелланда }\end{array}$ & \multicolumn{2}{|c|}{ Потребность достижения } & $\begin{array}{l}\text { Потребность } \\
\text { властвования }\end{array}$ & \multicolumn{2}{|c|}{ Потребность соучастия } \\
\hline $\begin{array}{l}\text { Теория } \\
\text { Герцберга }\end{array}$ & \multicolumn{3}{|c|}{ Мотивирующие факторы } & \multicolumn{2}{|c|}{ Факторы здоровья } \\
\hline
\end{tabular}

Взаимодействие человека и группы всегда носит двусторонний характер; человек своим трудом, своими действиями способствует решению групповых задач, но и группа оказывает большое влияние на человека, помогая ему удовлетворять его потребности безопасности, любви, уважения, самовыражения, формирования личности, устранения беспокойств и т.п. Отмечено, что в группах с хорошими взаимоотношениями, с активной внутригрупповой жизнью люди имеют лучшее здоровье и. лучшую мораль, они лучше защищены от внешних воздействий и работают эффективнее, чем люди, находящиеся в изолированном состоянии либо в «больных» группах, пораженных неразрешимыми конфликтами и нестабильностью. Группа защищает индивида, поддерживает его и обучает как умению выполнять задачи, так и нормам и правилам поведения в группе.

Но группа не только помогает человеку выживать и совершенствовать свои профессиональные качества. Она меняет его поведение, делая человека зачастую существенно отличным от того, каким он был, когда находился вне группы. Эти воздействия группы на человека имеют много проявлений. Укажем на некоторые существенные изменения в поведении человека, происходящие под влиянием группы.

Bo-nервых, под общественным влиянием происходят изменения таких характеристик человека, как восприятие, мотивация, сфера внимания, система оценок и т.д. Человек расширяет сферу своего внимания за счет усиления внимания к интересам других членов группы. Его жизнь оказывается в зависимости от действий его коллег, и это существенно меняет его взгляд на себя, на свое место в окружении и на окружающих.

Bo-вторых, в группе человек получает определенный относительный «вес». Группа не только распределяет задания и роли, но и определяет относительную позицию каждого. Члены группы могут делать совершенно одинаковую работу, но иметь при этом разный «вес» в группе. И это будет дополнительной существенной характеристикой для индивида, которой он не обладал и не мог обладать, находясь вне группы. Для многих членов группы эта характеристика может быть не менее важной, чем их формальная позиция.

$B$-mpeтьux, группа помогает индивиду обрести новое видение своего «я». Человек начинает идентифицировать себя с группой, и это приводит к существенным изменениям в его мировосприятии, в понимании своего места в мире и своего предназначения.

$B$-четвертых, находясь в группе, участвуя в обсуждениях и выработке решений, человек может выдать также предложения и идеи, которые он никогда не выдал бы, если бы осмысливал проблему в одиночку. Эффект 


\begin{tabular}{|c|c|c|c|c|c|c|}
\hline \multirow{4}{*}{ Impact Factor: } & ISRA (India) & $=3.117$ & SIS (USA) & $=0.912$ & ICV (Poland) & $=6.630$ \\
\hline & ISI (Dubai, UAE & $=0.829$ & РИНЦ (Russia) & $=0.156$ & PIF (India) & $=1.940$ \\
\hline & GIF (Australia) & $=0.564$ & ESJI (KZ) & $=8.716$ & IBI (India) & $=4.260$ \\
\hline & JIF & $=1.500$ & SJIF (Morocco) & $=5.667$ & OAJI (USA) & $=0.350$ \\
\hline
\end{tabular}

воздействия на человека «мозговой атаки» существенно повышает творческий потенциал человека.

B-nяmblx, отмечено, что в группе человек гораздо в большей мере склонен принимать риск, чем в ситуации, когда он действует один. В ряде случаев эта особенность изменения поведения человека является источником более действенного и активного поведения людей в групповом окружении, чем, если бы они действовали в одиночку.

Неверно думать, что группа меняет человека так, как ей захочется. Часто многим воздействиям co стороны группы человек долго сопротивляется, многие воздействия он воспринимает только частично, некоторые он отрицает полностью. Процессы адаптации человека к группе и подстройки группы к человеку являются неоднозначными, сложными и зачастую достаточно длительными. Входя в группу, вступая во взаимодействие с групповым окружением, человек не только изменяется сам, но оказывает воздействие на группу, на других ее членов.

Находясь во взаимодействии с группой, человек пытается различными способами воздействовать на нее, вносить изменения в ее функционирование с тем, чтобы это было приемлемо для него, удобно ему и позволяло ему справляться со своими обязанностями. Естественно, и форма воздействия, и степень влияния человека на группу существенно зависят как от его личностных характеристик, его возможностей оказывать влияние, так и от характеристик группы. Человек обычно выражает свое отношение к группе с позиций того, что он считает. При этом его рассуждения всегда находятся в зависимости от той позиции, которую он занимает в группе, от выполняемой им роли, от возложенного на него задания и соответственно от того, какие цели и интересы он преследует сам лично.

Взаимодействие человека с группой может носить либо характер кооперации, либо слияния, либо конфликта. Для каждой формы взаимодействия может наблюдаться различная степень проявления. То есть, например, можно говорить о скрытом конфликте, о слабом конфликте или же о неразрешимом конфликте.

В случае кооперации между членом группы и группой устанавливаются доверительные и благожелательные отношения. Человек рассматривает цели группы как не противоречащие его целям, он готов к поиску путей улучшения взаимодействия, положительно, хотя и с переосмыслением собственных позиций, воспринимает решения группы и готов к поиску путей поддержания отношений с группой на взаимовыгодной основе.
При слиянии человека с группой наблюдается установление таких отношений между человеком и остальной частью группы, когда каждая из сторон рассматривает другую как органически единую с ней составляющую целого, являющегося группой. Человек строит свои цели исходя из целей группы, в значительной мере подчиняет свои интересы интересам группы и идентифицирует себя с группой. Группа, в свою очередь, также старается смотреть на индивида не как на исполнителя определенной роли, а как на полностью преданного группе человека. В этом случае группа берет на себя заботу о человеке, рассматривая его проблемы и трудности как свои, старается оказать ему содействие в решении не только производственных задач, но и в решении его личных проблем.

Естественно, организация заинтересована в том, чтобы ее члены вели себя определенным образом.

Возможный подход к решению данной проблемы - это подбор людей с определенными качествами, которые могут гарантировать желаемое для организации поведение ее членов. Однако следует признать, что данный подход имеет ограниченное применение, так как, вопервых, не всегда можно найти людей с необходимыми характеристиками, во-вторых, нет абсолютной гарантии, что они будут вести себя обязательно таким образом, как этого ожидает организация, и, в-третьих, требования к поведению членов организации со стороны организационного окружения могут меняться во времени, входя в противоречие с теми критериями, по которым люди отбирались в организацию.

Второй подход, в принципе не исключающий первого, состоит в том, что организация влияет на человека, заставляя его модифицировать свое поведение в нужном для нее направлении. Данный подход возможен и базируется на том, что человек обладает способностью обучаться поведению, менять свое поведение на основе осознания своего предыдущего поведенческого опыта и требований, предъявляемых к его поведению со стороны окружения.[16]

Научение поведению можно определить как достаточно устойчивый во времени процесс изменения поведения человека на основе опыта, отражающего действия человека и реакиию окружения на эти действия.

Для научения поведению характерно наличие нескольких моментов.

Bo-nepвыx, научение может идти как на собственном опыте, так и на опыте других людей.

Bo-вторых, научение поведению не обязательно касается только собственно 


\begin{tabular}{|c|c|c|c|c|c|c|}
\hline \multirow{4}{*}{ Impact Factor: } & ISRA (India) & $=3.117$ & SIS (USA) & $=0.912$ & ICV (Poland) & $=6.630$ \\
\hline & ISI (Dubai, UAE & $=0.829$ & РИНЦ (Russia & $=0.156$ & PIF (India) & $=1.940$ \\
\hline & GIF (Australia) & $=0.564$ & ESJI (KZ) & $=8.716$ & IBI (India) & $=4.260$ \\
\hline & JIF & $=1.500$ & SJIF (Morocco & $=5.667$ & OAJI (USA) & $=0.350$ \\
\hline
\end{tabular}

реального поведения. Оно может касаться потенциального поведения, т.е. такого поведения, которое может быть осуществлено человеком, но которое не осуществляется им в его практике поведения.

B-mpeтьих, научение поведению всегда выражается в изменении человека. Даже в том случае, когда непосредственное поведение не претерпело изменений, человек уже становится другим, так как изменяется его поведенческий потенциал.

Выделяется три типа научения поведению.

Первый тип связан с рефлекторным поведением человека, с тем, что названо в учении И. Павлова условным и безусловным рефлексом. Если, например, начальник приходит к подчиненным тогда, когда он чем-то недоволен, раздражен и намерен сделать им выговор, то всякое появление начальника может вызывать страх у подчиненных, желание избежать этой встречи независимо от того, зачем он к ним пришел. То есть появление начальника вырабатывает условный рефлекс желания скрыться с его глаз.

Второй тип научения поведению базируется на том, что человек делает выводы из последствий своего предыдущего опыта, осознанно корректирует и меняет свое поведение. Теоретическое описание данного типа научения в первую очередь опирается на исследования Б. Скиннера, который создал основы теории зацепления осуществленного поведения в зависимости от его последствий. Суть этой теории сводится к тому, что если человек видит, что его поведение приводит к благоприятным последствиям, то он стремится повторять данное поведение, если же последствия оказываются негативными, то желание вести себя и далее аналогичным образом будет существенно понижено. То есть поведение человека задается сознательным осмыслением результатов предыдущего поведения.

Третий тип научения поведению - это обучение на основе наблюдения поведения. Обычно это наблюдение чужого поведения. Человек, регулярно наблюдая, как ведут себя окружающее его люди, автоматически начинает подстраивать к их поведению свое собственное поведение. Он перенимает их стиль и манеры, навыки выполнения операций и т.п. Часто проводится целенаправленное наблюдение чужого поведения с целью перенять для себя чтото полезное. С развитием средств видеозаписи объекта расширяются возможности наблюдения и, в частности, расширяется, объект наблюдения. Теперь человек может просматривать, записи своего собственного поведения, что также может существенно влиять на корректировку поведения. Очевидно, что все три типа научения поведению должны учитываться руководством организации в его попытках корректировать и формировать поведение членов организации. Не умаляя важности каждого из этих типов научения, тем не менее следует констатировать, что исключительно важную роль в процессе целенаправленного формирования поведения человека в организации играет второй тип научения.

Чему же учится человек в организации, какие стороны его поведения корректируются или меняются в процессе научения?

Bo-nервыlx, придя в организацию и далее осуществляя свою деятельность в ней, человек изучает свою функциональную роль: что он должен делать для лучшего выполнения работы, как осуществлять более эффективно работу, как и с кем коммуницировать в процессе работы. При этом он учится расставлять акценты в выполняемой им работе с точки зрения того, что считается в организации более важным, а что менее важным в его деятельности, за что идет вознаграждение, что входит в оценку качества его работы.

Bo-вmopblx, в организации человек учится выполнению формально-процедурных действий, таких, как заполнение различных анкет и форм, оформление заявок, назначение и, проведение встреч, передача, получение и осуществление ответа на полученную информацию, временное оставление рабочего места, приход и уход с работы, парковка автомобиля, ношение одежды определенного типа и т.д.

$B$-третьих, человек учится правильно понимать и занимать свое место в организации. Он узнает существующие в организации нормы, ценности и сложившиеся на их базе неформальные группы и отношения, учится правильно вести себя с коллегами и руководством, определяет для себя с кем иметь тесные отношения и от кого держаться подальше, кому доверять, на кого полагаться и кого опасаться.

$B$-четвертых, человек учится тому, как решать свои собственные задачи в организации, как добиваться своих целей. Так, например, он учится тому, как делать карьеру в организации. Либо тому, как добиваться определенных поощрений и вознаграждений. Может человек учиться и тому, как использовать возможности организации либо возможности её отдельных членов для того, чтобы решать свои личные задачи, не связанные с деятельностью организации. Работник может учиться тому, как избегать сложных и рискованных заданий, и даже тому, как, ничего не делая, создавать видимость, что он напряженно работает.[17]

Очевидно, последствия действий зависят от того, как вел себя человек, что он делал. Однако 


\begin{tabular}{|c|c|c|c|c|c|c|}
\hline \multirow{4}{*}{ Impact Factor: } & ISRA (India) & $=3.117$ & SIS (USA) & $=0.912$ & ICV (Poland) & $=6.630$ \\
\hline & ISI (Dubai, UAE & $=0.829$ & РИНЦ (Russia) & $=0.156$ & PIF (India) & $=1.940$ \\
\hline & GIF (Australia) & $=0.564$ & ESJI (KZ) & $=8.716$ & IBI (India) & $=4.260$ \\
\hline & JIF & $=1.500$ & SJIF (Morocco) & $=5.667$ & OAJI (USA) & $=0.350$ \\
\hline
\end{tabular}

непосредственно они зависят от тех, кто, оценивая действие человека, осуществляет компенсацию за его действия и усилия. В данном случае компенсация понимается в самом широком смысле как внешняя реакция на поведение человека, выражающаяся в том, что человек либо что-то приобретает, либо что-то теряет, чего-то добивается или же чего-то не достигает в результате осуществленных им в форме определенного поведения действий. Компенсация может производиться в различных видах — от материального вознаграждения или наказания до словесного одобрения или осуждения. Компенсация играет исключительно важную роль в научении поведению, так как она оказывает принципиальное влияние на то, происходит ли закрепление осуществленного поведения или же наступает отказ от него. Если отсутствует компенсация, вызывающая у человека представление о последствиях его действий, то фактически не происходит заметной модификации поведения, так как не происходит научения поведению. Поэтому компенсация в управлении людьми играет не только роль вознаграждения за произведенный труд либо роль средства удовлетворения потребностей работников, но и роль средства модификации поведения человека.

Процесс мотивации характеризуется четырьмя теориями, создающими основу для мотивации.

Теория ожидания: ожидание в цепочке "усилия исполнения"; ожидание в цепочке "исполнение - результат"; валентность результата.

Теория постановки целей. Четыре характеристики цели: сложность, специфичность, приемлемость, приверженность.

Теория равенства: сравнение своих результатов действий с результатами других.

Концепция партисипативного управления.

Самая общая концепция процесса мотивации сводится к следующим положениям. Человек, осознав задачи и возможное вознаграждение за их решение, соотносит эту информацию со своими потребностями, мотивационной структурой и возможностями, настраивает себя на определённое поведение, вырабатывает определенное расположение и осуществляет действия, приводящие к конкретному результату, характеризующемуся определенными качественными и количественными характеристиками.

Данная схема не раскрывает еще ни механизма вознаграждения, ни собственно содержания вознаграждения, сущности и содержания оценки, ни превращения оценки в решение. В современной управленческой мысли и практике существует ряд теорий, которые достаточно подробно и на операционном уровне описывают процесс мотивации. Наиболее известные из них - это теория ожидания, теория постановки целей, теория равенства и теория партисипативного управления. Они пытающихся объяснить, почему люди готовы осуществлять определенные действия, затрачивая большие или меньшие усилия. И, объясняя это, они дают менеджерам ключ к построению действенной системы мотивирования людей, т. е. как следует воздействовать на людей, чтобы побуждать их к результативной работе.

Поведение человека постоянно связано с выбором из двух иди нескольких альтернатив. От того, чему человек отдает то или иное предпочтение, зависит, что и как он делает, как он себя ведет и каких результатов он добивается. Теория ожидания разработана для того, чтобы дать ответ на вопрос, почему человек делает тот или ивой выбор, сталкиваясь с несколькими альтернативами, и насколько он мотивирован добиваться результата в соответствий, со сделанным выбором. В самом обобщенном виде теорию ожидания можно сформулировать как учение, описывающее зависимость мотивации от двух моментов: как много человек хотел бы получить и насколько возможно для него получить то, что он хотел бы получить, в частности, как много усилий он готов затрачивать для этого. Например, начинающий бизнесмен из провинции приезжает на переговоры о начале совместного бизнеса с представителями крупных фирм, расположенных в городе, являющемся признанным центром деловой активности. Для поддержания своего реноме он не будет останавливаться в гостинице, имеющей репутацию второсортной, хотя и являющейся дешевой. В то же время у него нет средств, чтобы остановиться в шикарной гостинице. Поэтому, по-видимому, он остановится в такой гостинице, которая является достаточно престижной и на проживание в которой у него хватит средств.

Процесс мотивации по теории ожидания складывается как бы из взаимодействия трех блоков: 1) усилия; 2) исполнение; 3) результат. Теория ожидания изучает и описывает взаимодействие этих трех блоков. При этом усилия рассматриваются как следствие, и даже результат мотивации. Исполнение рассматривается как следствие взаимодействия усилий, личных возможностей и состояния среды, а результат, как функция, зависящая от исполнения и, от степени желания получить результаты определенного типа.

Теория ожидания объясняет то, как строится процесс мотивации человека к деятельности, исходя из увязки в единое целое представлений человека о необходимых для выполнения работы усилиях, ее практическом исполнении и 


\begin{tabular}{|c|c|c|c|c|c|c|}
\hline \multirow{4}{*}{ Impact Factor: } & ISRA (India) & $=3.117$ & SIS (USA) & $=0.912$ & ICV (Poland) & $=6.630$ \\
\hline & ISI (Dubai, UAE & $=0.829$ & РИНЦ (Russia & $=0.156$ & PIF (India) & $=1.940$ \\
\hline & GIF (Australia) & $=0.564$ & ESJI (KZ) & $=8.716$ & IBI (India) & $=4.260$ \\
\hline & JIF & $=1.500$ & SJIF (Morocco & $=5.667$ & OAJI (USA) & $=0.350$ \\
\hline
\end{tabular}

результатах, ожидаемых в ответ на выполненную работу. При этом ключевыми точками концентрации внимания теории являются: 1) ожидания по цепочке «усилия - исполнение»; 2) ожидания по цепочке «исполнение - результаты второго уровня и 3) валентность результатов.

В соответствии с теорией ожидания, мотивация человека к исполнению работы зависит от того, насколько он заинтересован или не заинтересован выполнять ее, насколько работа привлекательна для него. Принимая решение по поводу того, что делать и какие усилия затрачивать, человек обычно отвечает самому себе на вопрос, касающийся того, насколько нужно ему это делать. То есть при выборе альтернативы человек думает о том, если он поведет себя соответствующим образом, будет соответствующим образом исполнять работу, приведет ли это к определенному результату первого уровня. В этом случае у него формируется ожидание результата первого уровня. Кроме этого, человек отвечает на вопрос о том, что он получит в результате успешного выполнения работы.

Это уже выработка ожидания результатов второго уровня. И, наконец, он решает для себя, насколько ценным будет для него этот результат, т.е. он оценивает валентность результата второго уровня. В зависимости от того, к какой окончательной оценке человек придет, будет формироваться его мотивация на выполнение работы.[18]

Основные положения теории ожидания состоят в следующем.

Bo-nepвblx, так как данная теория подчинена идее поиска ответа на вопрос, как мотивация влияет на выполнение работы, то исходный постулат состоит в том, что исполнение определяется произведением значений двух факторов: возможности человека и его мотивации.

Bo-вmopыx, утверждается, что мотивация задается произведением величины ожидания результатов первого уровня на величину валентности результатов первого уровня. И, наконец,

в-третьих, валентность результатов первого уровня задается произведением величины валентности результатов второго уровня на ожидания отдельных результатов второго уровня. Человек выбирает ту альтернативу, где будет выше мотивация.

Используя различные приемы, менеджер для успешного управления подчиненными должен построить управление организацией таким образом, чтобы работник был уверен, что, работая на достижение организационных целей, он тем самым создает условия для наилучшего достижения результатов второго уровня.
В теории ожидания считается, что для того, чтобы смог осуществиться процесс мотивирования, должен быть выполнен ряд предварительных условий. Такими условиями являются:

- наличие y работников достаточно высокой степени ожидания результатов первого уровня;

- наличие достаточно высокой степени ожидания результатов второго уровня $u$

- суммарная неотрицательная валентность результатов второго уровня.

На практике это означает, что работник должен иметь устойчивое представление о том, что от его усилий зависят результаты его труда, что из результатов его труда вытекают для него определенные последствия, а также то, что результаты, получаемые им, в конечном счете, имеют для него ценность. При отсутствии одного из этих условий процесс мотивирования становится исключительно сложным или же даже неосуществимым.

Делая общий вывод относительно теории ожидания, необходимо отметить, что она исходит из того, что люди осуществляет свои действия в соответствии с тем, к каким возможным последствиям для них эти действия могут привести. Люди на основе доступной им информации делают выбор одной из альтернатив действия, исходя из того, что они получат в результате и какие усилия они должны будут затратить, чтобы достичь этого результата. То есть, по теории ожидания, человек ведет себя в соответствии с тем, что, по его мнению, произойдет в будущем, если он произведет определенные затраты усилий.

Теория постановки целей исходит из того, что поведение человека определяется теми целями, которые он ставит перед собой, так как именно ради достижения поставленных перед собой целей он осуществляет определенные действия. При этом предполагается, что постановка целей это сознательный процесс, а осознанные цели и намерения - это то, что лежит в основе определения поведения человека.

В общей виде базисная модель, описывающая процесс постановки целей, выглядит следующим образом. Человек с учетом эмоциональной реакции осознает и оценивает события, происходящие в окружении. На основе этого он определяет для себя цели, к достижению которых он намерен стремиться, и, исходя из поставленных целей, осуществляет определенные действия - выполняет определенную работу. То есть ведет себя определенным образом, достигает определенного результата и получает от этого удовлетворение.

Теория постановки целей утверждает, что уровень исполнения работы непосредственно или опосредованно в значительной степени зависит от четырех характеристик целей: 


\begin{tabular}{|c|c|c|c|c|c|c|}
\hline \multirow{4}{*}{ Impact Factor: } & ISRA (India) & $=3.117$ & SIS (USA) & $=0.912$ & ICV (Poland) & $=6.630$ \\
\hline & ISI (Dubai, UAE & $=0.829$ & РИНЦ (Russia & $=0.156$ & PIF (India) & $=1.940$ \\
\hline & GIF (Australia) & $=0.564$ & ESJI (KZ) & $=8.716$ & IBI (India) & $=4.260$ \\
\hline & JIF & $=1.500$ & SJIF (Morocco & $=5.667$ & OAJI (USA) & $=0.350$ \\
\hline
\end{tabular}

- сложность;

- cпецифичность;

- приемлемость;

- приверженность.

Эти четыре характеристики цели влияют как, собственно, на цель, так и на те усилия, которые человек готов затрачивать, чтобы достичь поставленной перед ним цели.

Сложность цеели отражает степень профессиональности и уровень исполнения, необходимый для ее достижения. Существует непосредственная связь между сложностью цели и выполнением работы. Чем сложнее цели ставит перед собой человек, тем лучших результатов он добивается. Исключение составляет тот случай, когда ставятся цели нереалистично высокие, которые в принципе не могут быть достигнуты. В этом случае, как утверждает теория постановки цели, результат действий не превышает результата, которого добиваются те, кто ставил умеренные, но достижимые цели. Поэтому повышение целей, хотя оно и оправданно, может приводить $\kappa$ повьлшению результатов труда только в том случае, если будет сохраняться шанс достижения изелей.

Специфичность ичели отражает количественную ясность цели, ее точность и определенность. Экспериментальными исследованиями было установлено, что более конкретные и определенные цели ведут к лучшим результатам, к лучшему исполнению работы, чем цели, имеющие широкий смысл, с нечетко определенным содержанием и границами. Человек, имеюший цели слишком широкого смысла и содержания, демонстрирует такое же исполнение работы, как и тот, кто совершенно не имеет иелей. В то же время слишком большое сужение целей может привести к тому, что за бортом рассмотрения у человека могут остаться важные аспекты осуществляемой им деятельности. Это также негативно скажется на исполнении им своей работы.

Приемлемость ичели отражает степень, до которой человек воспринимает цель как свою собственную. Приемлемость цели оказывает существенное влияние на то, как воздействуют на исполнение работы сложность и специфичность цели. Если человек не приемлет цель, то и сложность, и специфичность цели будут иметь очень слабое влияние на исполнение работы. Приемлемость цели человеком напрямую зависит от того, воспринимается ли она им как достижимая, и от того, какие выгоды он может получить при достижении цели. Если выгоды не очевидны, то цель может быть не принята. Поэтому в руководстве организаџия должно существовать четкое осознание значимости, важности проведения действий, которые бы делали цель достижимой, выгодной, справедливой и безопасной в представлении работника.

Приверженность цели отражает готовность затрачивать усилия определенного уровня для достижения цели. Это очень важная для уровня; и качества исполнения характеристика цели, так как она может играть решающую роль на стадии исполнения, если реальность, трудности выполнения работы будут существенно отличаться от того, какими они представлялись на стадии постановки цели. Приверженность цели может возрастать по мере исполнения работы, а может и понижаться. Поэтому руководство должно постоянно отслеживать уровень приверженности цели со стороны работников и осушествлять необходимые меры для поддержания ее на должном уровня.[18]

В теории постановки целей при рассмотрении зависимости исполнения от целей подчеркивается, что качество исполнения зависит не только от определяемых иелью усилий работника, но и от двух групп факторов: 1) организациионные факторы и 2) способности работника. При этом данные группы факторов могут влиять не только на качество и содержание исполнения, но и на цели, оказывая тем самым опосредованное влияние на мотивацию и, следовательно, дополнительное влияние на исполнение. Так, например, если в работе слабо присутствует обратная связь от результатов труда, то это может снижать степень влияния цели на усилия работника по выполнению работы.

Последним шагом процесса мотивации в теории постановки цели является удовлетворенность работника результатом. Особое значение данного шага состоит в том, что он не только завершает цепочку процесса мотивации, но и является исходным для осуществления следующего цикла мотивации.

Человек осуществляет определенные действия в соответствии с давлением на него совокупности внутренних и внешних по отношению к нему сил. Совокупность этих сил, называемая мотивацией, вызывает у людей далеко не одинаковую реакцию. Поэтому невозможно однозначно описать процесс мотивации. В то же время на основе эмпирических исследований было разработано несколько концепций, описывающих факторы, влияющие на мотивацию и содержание процесса мотивации.

Так называемые теории содержания мотивации основное внимание уделяют тому, как различные группы потребностей оказывают влияние на поведение человека. Широко признанными концепциями этой группы являются теория иерархии потребностей Маслоу, теория ERG Альдерфера, теория двух факторов Герцберга и теория приобретенных потребностей МакКлелланда. Несмотря на принципиальные 


\begin{tabular}{|c|c|c|c|c|c|c|}
\hline \multirow{4}{*}{ Impact Factor: } & ISRA (India) & $=3.117$ & SIS (USA) & $=0.912$ & ICV (Poland) & $=6.630$ \\
\hline & ISI (Dubai, UAE & $=0.829$ & РИНЦ (Russia & $=0.156$ & PIF (India) & $=1.940$ \\
\hline & GIF (Australia) & $=0.564$ & ESJI (KZ) & $=8.716$ & IBI (India) & $=4.260$ \\
\hline & JIF & $=1.500$ & SJIF (Morocco & $=5.667$ & OAJI (USA) & $=0.350$ \\
\hline
\end{tabular}

отличия этих концепций, они тем не менее имеют нечто общее в своей основе, что отражает определенную общность в мотивации человека к действиям.

Процесс мотивации раскрывается в теориях, пытающихся объяснить, почему люди готовы осуществлять определенные действия, затрачивая большие или меньшие усилия. Теория ожидания, теория постановки целей, теория равенства и теория партисипативного управления, объясняя то, как следует воздействовать на людей, чтобы побуждать их к результативной работе, дают менеджерам ключ к построению действенной системы мотивирования людей для успешной реализации поставленных перед ними задач.

На рынке складывается специфическая культурная картина, сложная для понимания. Культурой покупателя государство всерьез не интересуется. Прежний опыт культурного просвещения и воспитания изгнан. «Свято место пусто не бывает» и вместо государства пришли организации из структуры гражданского общества, у которых нет ни официальных полномочий, ни действенных механизмов, ни требуемых финансовых средств. Ученые экономисты убеждают предпринимателей, что нужно отсекать все, не входящее непосредственно в производство, сокращая расходы, повышая рентабельность. Поступая так, предприниматели загоняют себя в ловушку стихийности и капризов рыночной стихии, отказываясь от рычагов управления спросом.

«Рачительная экономка», приходящая на смену нынешнему нерационально устроенному массовому производству, ориентированному на абсолютизацию свободы выбора товара потребителем, когда ассортимент обязан удовлетворять запрос здесь и сейчас, иначе продавец потеряет клиентов и поставит под вопрос продолжение своего бизнеса, «завязана» на знание потребности конкретного покупателя. Разумеется, такое знание специфично, оно ориентировочное, относительное, условное, больше похоже на знание предположение, но всетаки знание в отличие от абстрактной установки типа: покупатель пришел за товаром, и он должен его купить, мы же обязаны ему помочь. Как конкретно? Не знаем, поэтому инициируем его желание ассортиментом. Определенная логика и этика в подобных размышлениях присутствуют. Сдерживает от поддержки цена этой логики высокий уровень издержек и нагрузки на естественную среду. Их ведь не спишут, распределят по потребителям, увеличив цену покупки.

«Привлекательность товара» способна стать магнитом, инициирующим интерес покупателя. Недаром В.И Даль толковал «привлекательность» как «притягательность», «магнетизм». Экономическая система формируется производственными отношениями, радикальных преобразований существующей системы экономики поэтому не будет, произойдет перестройка, перезагрузка, изменяющая не систему, а порядок функционирования системы, векторная эволюция экономической политики. Экономическая система пройдет оптимизацию путем рационализации затрат, минимизации расходов на ассортимент.

Выигрывает ли потребитель? Видимо, да, при условии, что производители и продавцы не поскупятся на исследовательские работы потребительского спроса. Здесь уже простейшими исследованиями не обойтись, потребуется глубокий анализ и комплексирование разных подходов экономического (маркетингового), социологического, культурологического, эргономического, сангигиенического, акцентирование научных исследований на региональные, национальные особенности. Откроется перспектива реального участия в процессе студентов разного уровня, ускоряя их квалификационное становление.

Что же касается культурной организации рынка, то ее стержнем рационально сделать работу с покупателем и производителем, реальным предметом (объектом) отношений, которых является товар, как совокупность свойств, способных удовлетворить всех субъектов рынка. Товар перейдет из собственности одного в собственность другого только при наличии консенсуса. Консенсус и призван обеспечить рынок. Консенсус - мера рыночной культуры.

Когда же на рынке перейдут от представления о консенсусе к пониманию консенсуса, рынок обретет статус «культурной организации». Можно ускорить этот процесс? Безусловно. Нужно организовать работу на обоих фронтах. И покупатель, и продавец должны быть подготовлены культурно к встрече на рынке. Выполнение действительной миссии рынка определяется качеством информационнонаучного его оснащения.

Социальная функция рынка удовлетворение социокультурных и естественнонеобходимых потребностей массового покупателя, способствуя тем самым национальному развитию и политическому прогрессу. Экономическая задача товарного рынка - вовлечь в производство финансовые резервы населения страны, а они немалые, реально сравнимые с годовым бюджетом России.

Конечный этап рыночных отношений реализация товара, следовательно управлять рынком следует через условия реализации товара, 


\begin{tabular}{|c|c|c|c|c|c|c|}
\hline \multirow{4}{*}{ Impact Factor: } & ISRA (India) & $=3.117$ & SIS (USA) & $=0.912$ & ICV (Poland) & $=6.630$ \\
\hline & ISI (Dubai, UAE & $=0.829$ & РИНЦ (Russia & $=0.156$ & PIF (India) & $=1.940$ \\
\hline & GIF (Australia) & $=0.564$ & ESJI (KZ) & $=8.716$ & IBI (India) & $=4.260$ \\
\hline & JIF & $=1.500$ & SJIF (Morocco & $=5.667$ & OAJI (USA) & $=0.350$ \\
\hline
\end{tabular}

создавая благоприятные условия востребованности товара. Такое управление эффективно и в отношении потребителя, и производителя. Построение рынка по принципу: «здесь и сейчас покупатель должен удовлетворить свой запрос», экономит время и возможно незначительные финансовые средства потребителя, но противоестественно, ибо расточительно для общества и природы. Это «пижонство» по причине политической близорукости.

Государство в состоянии воздействовать на этот процесс через контроль за производством и потреблением, разумеется, в соответствии с законами экономики.

C учетом сказанного можно попытаться сформулировать определение того, что такое расположение. При этом надо иметь в виду, что существует несколько различных взглядов на то, что такое расположение, и однозначного и совершенно четкого определения этого свойства личности дать невозможно.

В общем виде расположение можно определить как априорное отношение к человеку, группе людей, явлениям, организациям, процессам u вещам, определяющее положительную или негативную реакцию на них.

Расположение имеет три компоненты. Вопервых, это та часть, которая отражает чувства человека по отношению к объекту: нравится ли он ему или нет. Данная часть называется воздействующей частью расположения. Вовторых, это знания об объекте, которыми располагает человек. В-третьих, это намерение по поводу того, как вести себя по отношению к объекту. Объединяясь вместе, эти три части формируют расположение человека к объекту, в котором находят динамическую увязку связи между знанием человека об объекте, его чувствами по отношению к этому объекту и его намерениями в отношении этого объекта.

Важными для эффективного управления и установления хороших отношений в организации являются три. типа расположения:

- удовлетворенность работой; - увлеченность работой; - приверженность организации.

То, насколько у работников развиты эти расположения, существенно определяет результаты их работы, количество прогулов, текучесть кадров и т.п. Удовлетворенность работой оказывает очень сильное влияние на чувства человека по отношению к работе, поэтому ее можно отнести скорее к воздействующей компоненте расположения. Степень удовлетворенности работой зависит от множества факторов, как внутренних, так и внешних по отношению к человеку.[19]

Однако при большом разнообразии факторов и различной направленности их влияния на человека выделяется восемь характеристик работы, от которых достаточно устойчиво зависит степень удовлетворенности работой:

- характер и содержание работы; - объем выполняемой работы;

- состояние рабочего места и его окружение (шум, освещенность, комфортность, температура воздуха и т.д.)- сослуживцы;

руководство (начальство, стиль руководства, участие в управлении);

- оплата работы (все формы компенсации);

- возможности продвижения по работе; распорядок, правила поведения.

Данные характеристики носят достаточно общий характер. Применительно к каждой реальной работе они могут быть конкретизированы либо дополнены в зависимости от характера деятельности организации, ее характеристик и т.П. Практика показывает также, что приоритетность этих характеристик также может существенно различаться как у отдельных членов внутри организации, так и у различных организаций. И, наконец, в связи со стабильной удовлетворенностью отдельными характеристиками работы влияние на удовлетворенность работой со временем могут начинать оказывать новые или же ранее малозначимые характеристики работы. Поэтому для успешного управления и создания положительного расположения в отношении организации необходимо регулярно проводить исследования с целью выяснения степени удовлетворенности сотрудников организации своей работой.

Стабильно большое влияние на повышение удовлетворенности работой оказывает характер и содержание работы. Поэтому рассмотрим более подробно влияние отдельных составляющих этого фактора.

Длительное время стандартизации $u$ специализация работы рассматривались и на практике выступали сильными источниками повышения производительности в работе. Чем выше стандартизация и специализация, тем выше производительность в работе. Однако зависимость между удовлетворенностью ею, и ее стандартизацией и специализацией носит иной характер. Если работа абсолютно не стандартизирована, то удовлетворенность работой находится на низком уровне. По мере увеличения специализации и стандартизации она начинает расти, но до определенного момента, после которого она начинает быстро снижаться. При полной стандартизации удовлетворенность падает до такого же низкого уровня, как если бы работа была абсолютно не стандартизирована. Поэтому руководство должно думать, как 


\begin{tabular}{|c|c|c|c|c|c|c|}
\hline \multirow{4}{*}{ Impact Factor: } & ISRA (India) & $=3.117$ & SIS (USA) & $=0.912$ & ICV (Poland) & $=6.630$ \\
\hline & ISI (Dubai, UAE & $=0.829$ & РИНЦ (Russia) & $=0.156$ & PIF (India) & $=1.940$ \\
\hline & GIF (Australia) & $=0.564$ & ESJI (KZ) & $=8.716$ & IBI (India) & $=4.260$ \\
\hline & JIF & $=1.500$ & SJIF (Morocco) & $=5.667$ & OAJI (USA) & $=0.350$ \\
\hline
\end{tabular}

снизить негативное влияние на удовлетворенность, работой, порождаемое чрезмерной специализацией и стандартизацией. Двумя наиболее распространенными способами осуществления этого являются ротация (перемещение работника с одного рабочего места на другое) и расширение производственных обязанностей путем постановки перед работником дополнительных задач.

Приверженность организации является расположением существенно более широким, чем увлеченность работой или же удовлетворенность работой. В современных условиях, когда все больше и больше организаций пытаются смотреть на человека не как на работника, выполняющего конкретную работу, а как на члена организации, стремящегося совместно с остальными ее членами привести организацию к достижению целей, значимость данного расположения становится исключительно высокой. Приверженность организации складывается из следующих составляющих. Вопервых, член организации разделяет и делает своими собственными цели организации и ее ценности. Во-вторых, член организации стремится оставаться в организации и сохраняет это стремление даже тогда, когда это может быть для него невыгодно. В-третьих, член организации готов не только стараться для организации, но и, если это надо, принести в жертву организационным интересам свои личные.

Приверженность организации - личная особенность каждого конкретного человека. Однако это не значит, что менеджмент не может развивать или усиливать это расположение. Существует ряд приемов, способствующих этому. И наиболее успешные современные системы управления в очень большой степени базируются на том, что они развивают у работников сильную приверженность организации и добиваются благодаря этому очень больших успехов.

Ценности так же, как и расположение, оказывают сильное влияние на предпочтения человека, на принимаемые им решения и поведение в коллективе. Однако между ценностями и расположениями есть огромная разница. Если последние определяют отношение человека к объекту по принципу «нравится -— не нравится», «люблю - не люблю» и всегда относятся к какому-то определенному объекту, то ценности задают предпочтение человека по принципу «допустимо - недопустимо», «хорошо — плохо», «полезно - вредно» и т.п. При этом ценности носят достаточно абстрактный и обобщающий характер, живут «самостоятельной» жизнью, независимо от конкретного человека, сформулированы в виде заповедей, утверждений, мудростей, общих норм и могут разделяться большими группами людей. Поэтому, если расположение всегда сугубо персонально, то носителями ценностей являются группы людей (например, ценности среднего класса), а каждый отдельный человек принимает какой-то набор ценностей, который он может и менять, но которому он следует в каждый конкретный момент времени.

Ценности можно определить как набор стандартов и критериев, которым человек следует в своей жизни. Это проявляется в том, что путем соответствующей оценки происходящих вокруг него явлений, процессов и людей человек принимает решения и осуществляет свои действия.

Ценности составляют сердцевину личности человека. Они достаточно устойчивы во времени и их не так много. Обычно ценности рассматриваются как нормативная база морали и фундамент поведения человека. Ценности бывают двух видов:

- ценности, относящиеся к цели жизни, желаемым результатам, исходу действия и т.п.;

- ценности, относящиеся к средствам, используемым человеком для достижения целей.

К первому виду ценностей относятся, например, ценности, касающиеся удобства жизни, красоты, мира, равенства, свободы, справедливости, удовольствия, самоуважения, общественного признания, дружбы и т.п.

Ко второму виду ценностей относятся ценности, касающиеся амбиций, открытости, честности, интеллектуальности, доброжелательности, ответственности, самоконтроля и т.п.

Верования могут быть разбиты на две большие группы.

Первую группу составляют описывающие абсолютные и относительные характеристики объекта верования, не имеющие оценочного характера. Например, автомобиль марки «Жигули» является комфортабельным автомобилем или автомобиль марки «Жигули» потребляет бензина меньше, чем автомобиль марки «Волга». Ко второй группе относятся те верования, которые носят оценочный характер.

Принципы в жизни многих людей играют очень большую роль, так как они систематически регулируют их поведение. Принципы находят воплощение в устойчивых нормах поведения, ограничениях, табу, устойчивых формах реакции на явления, процессы и людей. Принципы формируются на основе системы ценностей, являются устойчивой формой проявления системы ценностей и воплощением верований в виде определенных стандартов поведения, Люди не обязательно осознают, какие ценности и верования находят свое воплощение в отдельных принципах. Часто принципы принимаются 


\begin{tabular}{|c|c|c|c|c|c|c|}
\hline \multirow{4}{*}{ Impact Factor: } & ISRA (India) & $=3.117$ & SIS (USA) & $=0.912$ & ICV (Poland) & $=6.630$ \\
\hline & ISI (Dubai, UAE & $=0.829$ & РИНЦ (Russia) & $=0.156$ & PIF (India) & $=1.940$ \\
\hline & GIF (Australia) & $=0.564$ & ESJI (KZ) & $=8.716$ & IBI (India) & $=4.260$ \\
\hline & JIF & $=1.500$ & SJIF (Morocco) & $=5.667$ & OAJI (USA) & $=0.350$ \\
\hline
\end{tabular}

людьми как верования, и они следуют им в своей деятельности, не задаваясь вопросом по поводу оправданности следования этим принципам и почему они им следуют. Принципы могут вырабатываться людьми самостоятельно. Однако чаще всего они перенимаются из окружения вместе с воспитанием и другими формами познания окружающей действительности. Формируя поведения человека для обязательной реализации, поставленной перед ним задачи чтобы обеспечить успех всему коллективу предприятия. [21-22]

Все люди в чем-то похожи друг на друга. И это позволяет говорить о человеке вообще, рассуждать о его чертах, особенностях поведения и т.П.

Однако ни один конкретный человек не является обезличенным «человеком вообще». Каждый несет в себе что-то, что делает его уникальным, исключительным, т.е. человеком, обладающим индивидуальностью. Именно такой человек входит в организацию, именно такой человек выполняет определенную работу и играет определенную роль в организации, именно таким человеком нужно управлять, помогая ему раскрыть и задействовать свой потенциал в решении задач организации, создавая необходимые условия для его успешной работы, взаимодействия с организационным окружением и решения собственных жизненных проблем.

Индивидуальность человека складывается из трех начал. Во-первых, каждый человек в чемто сходен со всеми остальными. Во-вторых, каждый человек в чем-то одинаков с некоторыми другими индивидами. И, наконец, в-третьих, каждый человек в чем-то не похож ни на кого. В зависимости от того, как сочетаются эти «начала» армируется индивидуальность каждого конкретного человека. При этом, как бы ни строилось это сочетание, нужно всегда помнить, что человек всегда одновременно имеет общее с остальными и не похож на остальных.

Каждый человек обладает устойчивым набором черт и характеристик, определяющих его действия и поведение. Данные черты проявляют себя в достаточно длительном промежутке времени, благодаря чему можно зафиксировать и почувствовать индивидуальность человека.

Конкретный человек фиксируется окружением по его индивидуальности, так как индивидуальность человека обладает определенной устойчивостью, люди узнают друг друга и сохраняют определенное отношение друг к другу. В то же время следует отметить, что под влиянием опыта, общения с другими людьми, воспитания и образования происходит изменение индивидуальности человека, иногда очень существенное.
Индивидуальность человека формируется под влиянием трех групп факторов. Первую группу составляют наследственность и физиологические особенности человека. Наследственность сохраняет и передает внешние черты человека. Но не только. Исследования, проводимые с близнецами, показывают, что наследственность может нести в себе и передачу некоторых поведенческих черт. Физиология человека говорит о том, что в людях очень много общего определяющего их поведение. В частности, одинаковым для всех является общий синдром адаптации, отражающий физиологическую реакцию на раздражение.

Вторую группу факторов, формирующих индивидуальность человека, составляют факторы, проистекающие из окружения человека. В общем виде влияние этих факторов можно рассматривать как влияние окружения на формирование индивидуальности. Во-первых, сильное влияние на индивидуальность человека оказывает культура, в которой он формируется. Человек получает от общества нормы поведения, усваивает под влиянием культуры определенные ценности и верования. Во-вторых, индивидуальность человека сильно определяется семьей, в которой он воспитывался. В семье дети усваивают определенные поведенческие стереотипы, вырабатываются их жизненные установки, отношение к труду, людям, своим обязанностями т.п. В-третьих, на индивидуальность человека оказывает сильное влияние принадлежность к определенным группами организациям. $\mathrm{y}$ человека вырабатываются определенная идентификация, задающая для него некий тип индивида, с которым он себя олицетворяет, а также устойчивые формы поведения и, в частности, реакции на воздействие со стороны окружения. В-четвертых, формирование индивидуальности происходит под влиянием жизненного опыта, отдельных обстоятельств, случайных событий и т.п. Иногда именно эта группа факторов может приводить к существенному изменению индивидуальности человека.

Третью группу факторов, влияющих на формирование индивидуальности человека, составляют черты и особенности характера человека, его индивидуальность. То есть в данном случае ситуация с формированием индивидуальности выглядит следующим образом: индивидуальность оказывает влияние на свое собственное формирование и развитие. Связано это с тем, что человек играет активную роль в собственном развитии и не является только исключительно продуктом наследственности и окружения.

При всей глубине индивидуальности человека и ее разнообразии можно выделить 


\begin{tabular}{|c|c|c|c|c|c|c|}
\hline \multirow{4}{*}{ Impact Factor: } & ISRA (India) & $=3.117$ & SIS (USA) & $=0.912$ & ICV (Poland) & $=6.630$ \\
\hline & ISI (Dubai, UAE & $=0.829$ & РИНЦ (Russia & $=0.156$ & PIF (India) & $=1.940$ \\
\hline & GIF (Australia) & $=0.564$ & ESJI (KZ) & $=8.716$ & IBI (India) & $=4.260$ \\
\hline & JIF & $=1.500$ & SJIF (Morocco & $=5.667$ & OAJI (USA) & $=0.350$ \\
\hline
\end{tabular}

некоторые направления ее характеристики, по которым может быть описана индивидуальность.

Стабильность в поведении человека играет большую роль в установлении его взаимоотношений с окружением.

Самооценка, т.е. то, как люди смотрят на свое поведение, возможности, способности, внешность и т.п., оказывает сильное влияние на поведение человека.

Восприятие риска является важной поведенческой характеристикой, наглядно отражающей индивидуальность человека.

Догматизм обычно является чертой характера индивидов с ограниченным взглядом.

Комплексность осознания явлений как характеристика индивидуальности человека отражает его способность разлагать познаваемое явление на части и интегрировать, синтезировать общие представления или заключения об осознаваемом явлении.

Сфера, контроля отражает то, как индивид смотрит на источник факторов, определяющих его действия.

Как уже говорилось выше, организация ожидает, что человек будет выполнять определенным образом роль, для которой она его принимает. Человек также смотрит на организацию как на место, где он получает определенную работу, выполняет ее и получает соответствующее вознаграждение от организации. Однако взаимодействие человека и организации не сводится только к ролевому взаимодействию. Оно гораздо шире. Человек выполняет работу в окружении людей, во взаимодействии с ними. Он не только исполнитель роли в организации, но и член группы, в рамках которой он действует. При этом группа оказывает огромное влияние на поведение человека. А поведение человека, его действия вносят определенный вклад в жизнь группы.

Характерными особенностями группы являются следующие [7].

Bo-nервыx, члены группы идентифицируют себя и свои действия с группой в целом и тем самым во внешних взаимодействиях выступают как бы от имени группы.

Bo-вторых, взаимодействие между членами группы носит характер непосредственных контактов, личного разговора, наблюдения поведения друг друга и т.п.

$B$-третьих, в группе наряду с формальным распределением ролей, если таковое существует, обязательно складывается неформальное распределение ролей, обычно признаваемое группой.

Существует два типа групп: формальные $и$ неформальные. Оба эти типа групп имеют значение для организации и оказывают большое влияние на членов организации.
Формальные группы обычно выделяются как структурные подразделения в организации. функции и задачи.

Неформальные группы создаются не распоряжениями руководства и формальными постановлениями, а членами организации в соответствии сих взаимными симпатиями, общими интересами, одинаковыми увлечениями, привычками и т.п.

Жизнь группы, eе функционирование находится под влиянием трех факторов:

- характеристики членов группы;

- структурные характеристики группы;

- ситуационные характеристики.

К характеристикам членов группы, оказывающим влияние на ее функционирование, относятся личностные характеристики человека, а также способности, образование и жизненный опыт.

Структурные характеристики группь включают в себя:

- коммуникации в группе и нормы поведения;

- статус и роли;

- личные симпатии и антипатии между членами группы;

- силу и конформизм.

Первые две структурные характеристики группы относятся больше к организационной стороне анализа ее функционирования, поэтому они не будут рассмотрены здесь.

Симпатии; $и$ антипатии между людьми в основном носят индивидуальную окраску и подоплеку.

Bo-nервых, исключительно большое влияние оказывают личностные характеристики взаимодействующих.

Bo-вторых, на развитие и установление дружеских отношений между людьми, на развитие взаимной симпатии большое влияние оказывает наличие территориальной близости в расположении этих людей.

B-третьих, установление дружеских отношений находится в прямой зависимости от частоты встреч, а также от ожидания того, что эти встречи будут происходить достаточно часто в будущем.

$B$-четвертых, взаимоотношения между членами группы, их взаимные симпатии и антипатии, атмосфера дружественности в группе зависят от того, насколько успешно функционирование группы.

B-nяmblx, развитию дружеских отношений между членами группы способствует наличие одной цели, которой подчинены действия всех членов группы.

$B$-шестыx, положительная ориентация в отношении друг к другу возникает тогда, когда в 


\begin{tabular}{|c|c|c|c|c|c|c|}
\hline \multirow{4}{*}{ Impact Factor: } & ISRA (India) & $=3.117$ & SIS (USA) & $=0.912$ & ICV (Poland) & $=6.630$ \\
\hline & ISI (Dubai, UAE & $=0.829$ & РИНЦ (Russia & $=0.156$ & PIF (India) & $=1.940$ \\
\hline & GIF (Australia) & $=0.564$ & ESJI (KZ) & $=8.716$ & IBI (India) & $=4.260$ \\
\hline & JIF & $=1.500$ & SJIF (Morocco & $=5.667$ & OAJI (USA) & $=0.350$ \\
\hline
\end{tabular}

группе практикуется широкое участие всех членов группы в принятии решения.

Взаимная поддержка на базе симпатий и дружеских отношений, способствуя сплочению группы, может порождать синергический эффект, существенно повышающий результативность работы группы. Современная практика управления все более и более подтверждает наличие несомненных преимуществ у групповой формы организации труда перед

Пространственное расположение членов группы оказывает заметное влияние на их поведение. Одно дело, когда человек имеет постоянное место расположения, другое - когда он ищет каждый раз себе это место. Люди во время работы могут смотреть друг на друга, а могут быть расположены спиной друг к другу. И это также будет оказывать влияние на их работу и на их поведение в группе.

Выделяются три важные характеристики пространственного расположения индивида, от которых зависят взаимоотношения между человеком и группой.

Bo-nepвblx, это наличие постоянного или определенного места или территории. Человек знает: это мой стол, это мой станок, это мое рабочее место. Отсутствие ясности в данном вопросе порождает множество проблем и конфликтов в межличностных отношениях, а также значительно понижает удовлетворенность работой.

Bo-вторых, это личное пространство, т.е. то пространство, в котором находится тело только данного человека. Пространственная близость в размещении людей может порождать множество проблем, так как людьми не воспринимается близкое расположение к ним других людей без учета возраста, пола и т.п.

$B$-третьих, это взаимное расположение мест. Отмечено, что если рабочие места отгорожены друг от друга, то это способствует развитию формальных отношений. Наличие рабочего места руководителя группы в общем пространстве способствует активизации и консолидации группы. Если человек занимает рабочее место во главе стола, то это в глазах других членов группы автоматически ставит его в позицию лидера. Руководство, зная эти и другие вопросы расположения членов группы, может добиваться значительного эффекта и повышения результативности работы группы только за счет правильного размещения рабочих мест.

Влияние задач, решаемых группой, на функционирование группы и на поведение и взаимодействие членов группы очевидно. Однако очень сложно установить зависимость между типами задач и их влиянием на жизнь группы. Известно, что задачи и функции, выполняемые группой, влияют на стиль руководства, а также на стиль общения между людьми. В случае слабо структурированных или неструктурированных задач наблюдается большее давление группы на индивида и большая взаимозависимость действий, чем в случае хорошо структурированных задач. Можно указать на несколько характеристик задачи, на которые важно обращать внимание для того, чтобы попытаться определить как решение данной задачи будет влиять на группу в целом и на поведение ее членов.

Bo-nервых, надо определить, как много взаимодействий будет возникать между членами группы в процессе решения задачи и как часто они будут коммуницировать друг с другом.

Bo-вторых, надо выяснить, насколько действия, выполняемые отдельными людьми, взаимозависимы и оказывают взаимное влияние.

$B$-третьих, важно установить, насколько решаемая задача является структурируемой.

Возможны четыре комбинации этих факторов:

- низкая взаимозависимость - низкая дифференциация в оплате;

- низкая взаимозависимость - высокая дифференциация в оплате;

высокая взаимозависимость-низкая дифференциация в оплате;

высокая взаимозависимость - высокая дифференциация в оплате.

Первый и четвертый случаи порождают много проблем во взаимоотношениях между членами группы. Напротив, второй и третий случаи могут способствовать успешному функционированию группы и развитию благоприятных отношений между членами группы, гарантируя коллективу предприятия устойчивые технико-экономические показатели результатов их деятельности

Необходимость совершенствования системы менеджмента качества на предприятиях легкой промышленности обусловлено следующими важными причинами. Во-первых, это повышение доверия потенциальных потребителей к продукции, которую выпускает данное предприятие. Во-вторых, это возможность значительно укрепить свое положение на уже существующих рынках, а также значительно расширить сферы влияния путем выхода на новые отечественные и зарубежные рынки. И втретьих - это значительное повышение производительности труда любого промышленного предприятия, на котором предполагается внедрение СМК с использованием партисипативного управления. [23]

В истории проблемы качества выделяются два периода. В течение первого серьезный интерес к тому, что есть качество, был ограничен 


\begin{tabular}{|c|c|c|c|c|c|c|}
\hline \multirow{4}{*}{ Impact Factor: } & ISRA (India) & $=3.117$ & SIS (USA) & $=0.912$ & ICV (Poland) & $=6.630$ \\
\hline & ISI (Dubai, UAE & $=0.829$ & РИНЦ (Russia & $=0.156$ & PIF (India) & $=1.940$ \\
\hline & GIF (Australia) & $=0.564$ & ESJI (KZ) & $=8.716$ & IBI (India) & $=4.260$ \\
\hline & JIF & $=1.500$ & SJIF (Morocco & $=5.667$ & OAJI (USA) & $=0.350$ \\
\hline
\end{tabular}

в основном профессиональной теорией. Качество и его системное положение пытались определить философы, однако, и в многочисленных философских спорах понятие «качество» не принадлежало к числу главных проблем.

Актуализация теории качества оказалась в зависимости от степени разработанности системообразующего философского понятия «бытие» в контексте базовых производных от него понятий, т.е. тех понятий, которые помогают осуществить восхождение от предельно абстрактного утверждения существования с единственным отличающим свойством быть, существовать, к конкретному пониманию с устоявшимся содержанием, благодаря ответам на производные вопросы, такие, как «Из чего есть все?», «За счет чего все существует?», «Есть ли небытие?», «В каких системных формах бытие обретает свою определенность?».

По-видимому, именно последний из перечисленных вопросов вывел философию на «тропу» того толкования качества, которое «зацепило» не только тех, кто «обустраивал» принципиально новый в человеческой истории тип мировоззрения. Логично предположить, что проблема субстанции бытия, как первый шаг к теории качества, вряд ли кого волновал за пределами ограниченного сообщества философов. Всё свидетельствует о том, что интересно это было тем, чей взор был обращен в Космос, в глубины его конструкции, а подавляющее большинство земляков - философов находилось во власти земных проблем.

Для масс разнообразие и возможность выбора благ, по существу, были не доступны. Плебеи требовали: «Хлеба и зрелищ!». Праздником жизни во всем разнообразии ее проявления наслаждалась немногочисленная аристократия. Проблема качества жизни решалась в соответствии с социокультурной архитектурой общества. Проблема эта бесспорно имела место, но вызреть в актуальную для общества не могла. Причина проста - отсутствие достаточного уровня массовой востребованности качественного продукта.

Проблема качества обрела масштабы социальной актуальности в условиях перехода к экономике массового производства, демократизации общественных отношений, развития просвещения, доступности образования и других культурных ценностей. Чтобы вопрос о качестве сделался одним из наиболее важных для общества, нужно было, чтобы он стал актуальным для большинства тех, кто образует это общество. Без права на свободу и покупательской способности делать выбор, «качество» не способно быть среди приоритетов массового сознания. Элитные же запросы на качество разрабатываются в эксклюзивных, нетрадиционных теориях, главная цель которых не достижение истины, а удовлетворение потребности заказчиков.

Разумеется, о качественных и количественных характеристиках явлений естественного и искусственного происхождения знали задолго до того, когда эти признаки актуализировались в общественном бытии и отражающим его развитие сознании, но, в свете нашего исследования, существование знания качества де факто не столь значимо. Предмет исследования не осознание качества, а развитие понимания качества на разных горизонтах общественной истории.

Развитие - универсальное состояние всего существующего от простейших материальных субстратов до высших форм мышления. Совершенствовались и качество, и количественное его выражение, прояснялась зависимость качественно-количественных изменений. Смещались акценты внимания с количества на качество. Доказав свою эволюционную прочность, человечество переключалось на принцип: «брать не числом, а умением». На смену борьбы за выживание пришло стремление к качественному уровню жизни в широком диапазоне толкования. Началась борьба за достойную качественную жизнь.

Как показывает история, уйдя от дикости и варварства, заложив основы цивилизации, люди заметно изменились во внешних формах своего проявления, но в недра человеческой натуры цивилизация проникает медленно и тяжело. Биологическая история заложила в природу человека активное начало, совмещенное с развитой способностью мышления, заметно превосходящей все иные виды отражения. Но вся эта надстройка сформировалась над достаточно жестким животным каркасом, подчиненным системной цели выжить в борьбе. Условия борьбы трансформировались, внося коррективы в средства и формы, однако сама природная база оказалась весьма инерционной.

Переход от естественного эгоизма биологического уровня к разумно-деятельному эгоизму, несмотря на известные цивилизационные средства культивации, не отвечал прогнозам ни романтиков, ни реалистовоптимистов. Цивилизация отметилась не цивилизационными формами отношений в движении к качественной жизни, чем еще больше актуализировала интерес к качеству. Чтобы стать в ряд с самыми важными проблемами, качество должно было предстать в нескольких функциях: как цель, как средство, как условие развития всех социальных субъектов на всех уровнях жизнедеятельности. 


\begin{tabular}{|c|c|c|c|c|c|c|}
\hline \multirow{4}{*}{ Impact Factor: } & ISRA (India) & $=3.117$ & SIS (USA) & $=0.912$ & ICV (Poland) & $=6.630$ \\
\hline & ISI (Dubai, UAE & $=0.829$ & РИНЦ (Russia & $=0.156$ & PIF (India) & $=1.940$ \\
\hline & GIF (Australia) & $=0.564$ & ESJI (KZ) & $=8.716$ & IBI (India) & $=4.260$ \\
\hline & JIF & $=1.500$ & SJIF (Morocco & $=5.667$ & OAJI (USA) & $=0.350$ \\
\hline
\end{tabular}

История для историков - события и участники, выстроенные во временной последовательности, своего рода хронология значимых фактов общественной и, отчасти, личностной жизни. Философ и специалист-не историк видят в истории свои интересы. Философский и специальный интерес к истории продиктован потребностью понять диалектику процесса применительно к деятельности человека. Специалист стремится обнаружить в прошлом тенденции пути решения своей проблемы, подчас далеко не частной. Интуитивно еще на заре цивилизации термин история (historia) трактовался в смысле исследования искомого процесса в противоположность хронологическому описанию. У ионийцев повествование, рассказ о прошлом именовали логосом (logos). Лишь спустя время, уже в трудах основоположников философии логос приобрел современное значение - мысль, идея. И Геродот, и Фукидид понимали историю как осмысление хода, событий прошлого, необходимое для «наставлений в образе жизни» тем, кто живет в настоящем. Пройдя испытание временем, историзм укрепил свои позиции, стал идейной базой культурной памяти. Н.А. Бердяев утверждал: «От первых дней Творения...человек находится в историческом, и историческое находится в человеке. Погружение в глубь времен есть погружение внутрь себя». Прошлое растворяется во времени, оставляя нам, наряду с памятью о былом, думы о настоящем и ответственность за будущее. Новое всегда относительно. Гете был прав, говоря, что все умное уже известно, надо только еще раз это продумать. [24]

История - клад идей, золотая жила для мыслящего человека, чем бы он ни занимался. Различное отношение к истории есть совокупный результат действия двух причин: первая толкование времени, вторая - себя во времени. В дохристианский период истории время трактовали циклически, представляя его как сумму повторяющихся замкнутых на себя циклов. С христианством взгляд на время поменялся. Время предстало в качестве восхождения к бесконечному, разделившись на конечное земное и бесконечное внеземное. Противоположение циклического и вне циклического рассмотрения времени характерно для теологической теории. Нас оно не интересует, впрочем, как и свойства времени в их абстрактном виде.

После Г. Гегеля и К. Маркса актуально не представление о чем-то вообще, а погружение в конкретно-предметное, либо конкретноисторическое состояние того, что, оказывается, объектом исследования. В случае со временем, актуально анализировать не столько его универсальные свойства, определять, куда и как оно движется. Важно то, что все существующее во времени может состояться, только соответствуя этим объективным характеристикам времени. Существовать во времени, значит обладать свойствами времени. Данное положение универсально и для бесконечного многообразия отдельных явлений, и для необходимо присущих им признаком бытия, к которым принадлежат «качество» и «количество».

Стандартное понимание закона перехода количественных изменений в качественные упрощает взгляд на их связь. И Г. Гегель, и Ф. Энгельс были далеки от того смысла, который распространялся под прикрытием диалектической теории развития. Количество в качество не переходит непосредственно. Новое качество, качественное состояние возникает как переход из предшествующего качества. В изменившихся количественных условиях мера исчерпывает резерв устойчивости функционирования.

Мера - «качественное количество», она указывает на пределы изменения количества без существенных последствий для данного качества явления. Выход количественных показателей, необходимых для достигнутого качества, за границы меры неизбежно влечет качественные преобразования. Одновременно с потерей прежнего качества идет процесс рождения из него, на его основе нового качества, соразмерного изменившемуся количеству. Ключевое положение во взаимоотношениях качества с количеством занимает мера. О мере же специалисты по качеству предпочитают всерьез не рассуждать, сводя меру к количественным стандартам. Будто мера - это какое-то проходное состояние системы «качество-количество». Надо четко понимать объективную и функциональную роль меры в управлении, как качеством, так и количеством.

«Мера» не принадлежит ни качеству, ни количеству. Она выражает системный способ отношений качества и количества, связывает их. Итак, первое: количество и качество взаимодействуют через меру, мера опосредует их связь. Какую «выгоду» извлечет из настоящего заключения специалист-практик? Массовое производство, включая «рачительную» его разновидность, требует мерной характеристики, в противном случае сказочный сюжет о горшке с кашей или «цветике - семи цветике» вполне имеет шанс реального продолжения. Китайский ширпотреб - классический пример разрушения диалектического единства в системе «количество-качество».

Рынок, по сути своей, не способен быть контролером меры, регулирующей отношения в системе «количество - качество». С 


\begin{tabular}{|c|c|c|c|c|c|c|}
\hline \multirow{4}{*}{ Impact Factor: } & ISRA (India) & $=3.117$ & SIS (USA) & $=0.912$ & ICV (Poland) & $=6.630$ \\
\hline & ISI (Dubai, UAE & $=0.829$ & РИНЦ (Russia & $=0.156$ & PIF (India) & $=1.940$ \\
\hline & GIF (Australia) & $=0.564$ & ESJI (KZ) & $=8.716$ & IBI (India) & $=4.260$ \\
\hline & JIF & $=1.500$ & SJIF (Morocco & $=5.667$ & OAJI (USA) & $=0.350$ \\
\hline
\end{tabular}

приобретением оптовых форм развития, господствующего положения финансового капитала и его естественного порождения масштабных спекуляций и посредничества, современный рынок противопоставил себя производству и потерял интерес к состоянию производства. Рынок, используя специфику массового производства, насытился в меру своей извращенности и может позволить себе задавать качественные характеристики товаров.

Государство ведет себя на рынке, будто воспитатель в детском саду. Интересы рынка оно ставит выше интересов производителей и массового потребителя. Под «крышей» генеральной идеи - рынок тянет за собой производство, идет срастание рынка и государства. Качество -количественные оценки оказываются оттиснутыми в зону субъективного произвола. До тех пор, пока теория качества системно не выстроена, теория управления качеством будет строиться на эмпирических началах, которые не в состоянии охватить предмет управления в целом, и относительно значимы в ограниченной специфике производства. За неимением ничего лучшего ими пользуются, экстраполируя локальный опыт на другие условия, получают эффект за счет добавленных мер по адаптации, к сожалению, опять-таки временный и частичный.

В калейдоскопе истории смены способов управления качеством можно различить определенную логику. Жизнь же требует не «определенной» логики, а логической определенности в форме целостной, системно обоснованной теории качества в качестве методологической опоры построения универсальных принципов теории управления качеством. Исходной здесь должна быть идея системности отношений «качество-количество» в рамках меры их сосуществования.

Раскрыться в полной мере качеству помогает количество. Качественную вещь можно создать и в одном экземпляре, но, чтобы раскрыться качественному потенциалу производителя, единственного экземпляра (или произведения) явно недостаточно. Фирма Фаберже обеспечила себе известность уже первым брендовым изделием, но брендом сделалась за счет последующих успехов в создании коллекции.

Примером системного понимания качества в рамках меры - мерной определенностью служат мелкие серии, выпуск коллекционных монет, медалей. Качество фиксируется в границах количественной величины, служащей мерой его выражения. Дело здесь не только в обеспечении условий преференции для vip-потребителя продукции. Значима также зависимость объективных признаков качества от количества произведенных экземпляров. Массовое производство объективно сопряжено со снижением качества продукции. Мера пограничная служба качества, переход за мерное количество есть преступление против качества.

Массовый отечественный производитель вряд ли интересуется теорией качества. Она для него не актуальна. Если все же случайно кто-то наткнется на наши рассуждения, то, вероятнее всего, улыбнется их наивности. Пытаться с помощью теории перестроить российский рынок, придать ему цивилизованный вид - классическое донкихотство. Сначала надо организовать рыночное пространство посредством политической воли, законодательных инициатив и действенного, а не бутафорского, контроля за узаконенным порядком, вернуть на рынок производителя товара, убрав немереное количество посредников - спекулянтов.

Настоящий производитель не заинтересован в спекулятивных операциях. Ему для устойчивого развития необходим свой потребитель, который, кстати, в свою очередь, совсем не против, иметь своего определенного и доступного производителя в рамках нравственно - правовых отношений.

Чувство национального достоинства воспитывается историей и существующей реальностью. В школе можно учиться по самому лучшему учебнику истории, но кроме школьных уроков истории есть текущая жизнь, впечатляющая сильнее исторических экскурсов. На Востоке говорят: «сколько раз не повторяй халва, во рту сладко не будет». Теория всегда считалась лучшим практическим руководством, правда, в нормализованных обстоятельствах деятельности. Уходя в нелегальное и полулегальное положение, производитель отчуждается от качества и, естественно, от теории качества. Далее происходит подмена качества псевдо качеством и растут затраты на рекламную бутафорию. [21]

Качество деятельности человека отражает такой комплекс еe характеристик, который в максимальной степени соответствует идеальному представлению об успехе. Объектом управления является деятельность человека во всей совокупности еe факторов, характеристик и особенностей. Но любая деятельность человека представляет собой комплекс действий, направленных на решение какой-либо проблемы, позволяющей достигать поставленной цели. Следовательно, можно говорить об управлении качеством как управлении теми характеристиками деятельности человека, которые делают эту деятельность такой, какая необходима для надежного и реального достижения цели. Управление любыми процессами в итоге выливается в воздействие на 


\begin{tabular}{|c|c|c|c|c|c|c|}
\hline \multirow{4}{*}{ Impact Factor: } & ISRA (India) & $=3.117$ & SIS (USA) & $=0.912$ & ICV (Poland) & $=6.630$ \\
\hline & ISI (Dubai, UAE & $=0.829$ & РИНЦ (Russia & $=0.156$ & PIF (India) & $=1.940$ \\
\hline & GIF (Australia) & $=0.564$ & ESJI (KZ) & $=8.716$ & IBI (India) & $=4.260$ \\
\hline & JIF & $=1.500$ & SJIF (Morocco & $=5.667$ & OAJI (USA) & $=0.350$ \\
\hline
\end{tabular}

определенные их характеристики: производительность, надежность, своевременность, дизайн, эффективность и пр. Комплекс таких характеристик отражает качество деятельности. Вот почему можно говорить об управлении качеством как об особом подходе.

Чувство национального достоинства воспитывается историей и существующей реальностью. В школе можно учиться по самому лучшему учебнику истории, но кроме школьных уроков истории есть текущая жизнь, впечатляющая сильнее исторических экскурсов. На Востоке говорят: «сколько раз не повторяй халва, во рту сладко не будет». Теория всегда считалась лучшим практическим руководством, правда, в нормализованных обстоятельствах деятельности. Уходя в нелегальное и полулегальное положение, производитель отчуждается от качества и, естественно, от теории качества. Далее происходит подмена качества псевдо качеством и растут затраты на рекламную бутафорию.

Качество деятельности человека отражает такой комплекс еe характеристик, который в максимальной степени соответствует идеальному представлению об успехе.

Объектом управления является деятельность человека во всей совокупности ее факторов, характеристик и особенностей. Но любая деятельность человека представляет собой комплекс действий, направленных на решение какой-либо проблемы, позволяющей достигать поставленной цели.

Следовательно, можно говорить об управлении качеством как управлении теми характеристиками деятельности человека, которые делают эту деятельность такой, какая необходима для надежного и реального достижения цели. [22]

Управление любыми процессами в итоге выливается в воздействие на определенные их характеристики: производительность, надежность, своевременность, дизайн, эффективность. Комплекс таких характеристик отражает качество деятельности. Вот почему можно говорить об управлении качеством как об особом подходе.

В управлении существует цель и средства ее достижения. Причем между этими двумя факторами устанавливаются вполне определенные отношения. Это отношения конкретности, взаимообусловленности, прямого взаимодействия, корректировки, гибкости, подстройки.

В большинстве случаев нашего отечественного управления качество рассматривается не более чем средство достижения цели. Если учесть, что цели, как правило, недостаточно определенны, то и средства их достижения обладают таким же свойством. Качество в управлении присутствует как общая характеристика выпускаемой продукции, достигаемая посредством нормативов, стандартов, технического контроля.

Мировой опыт управления свидетельствует об изменении статуса качества в системе и процессах управления. В стратегических планах многих предприятий качество рассматривается как главная цель управления, которая определяет и прибыль, и имидж, и стабильность, и уверенность в конкуренции, и перспективность развития. Об этом свидетельствует хотя бы опыт Японии.

Современное управление требует постановки проблемы качества как цели управления, и достижение этой цели требует вполне определенных средств. В управлении качеством большое значение имеет понимание того, что качество не может быть достигнуто без учета всех его составляющих, без организации взаимодействия в системе управления по критериям качества. Во многих ранее создаваемых системах управления качеством главную роль играли характеристики продукции, свойства произведенного предмета, а не комплекс определенных характеристик, отражающих социально-экономический процесс функционирования и развития производства, качество социально-экономической системы вообще.[23]

Качество продукции есть следствие действия многих факторов - качества персонала, качества организации производства, качества техники и технологии, качества управления, конструктивных разработок. Всё это кажется очевидным, тем не менее, в реальной практике управления качеством не стало еще особым типом управления.

Проблема качества в управлении должна иметь статус цели и предмета управления. Это трудно, но необходимо, потому что надо иначе подходить к определению содержания решаемых в управлении проблем, оценивать их по весьма сложным факторам. Качество продукции можно увидеть, оценить, понять. Но качество деятельности фирмы, дающей хорошее качество продукции, определить и оценить трудно, тем более оценить потенциал качества. Не все можно оценивать по конечному результату, не все одинаково явно включает в себя конечный результат. Многое как бы выпадает в процессе его производства, получения, трансформируется в другие свойства. Вот почему качество продукции и качество деятельности - это не одно и то же, но последнее гораздо важнее для анализа управления, его организации, для постановки целей и ориентиров управления, выбора средств и методов управления. 


\begin{tabular}{|c|c|c|c|c|c|c|}
\hline \multirow{4}{*}{ Impact Factor: } & ISRA (India) & $=3.117$ & SIS (USA) & $=0.912$ & ICV (Poland) & $=6.630$ \\
\hline & ISI (Dubai, UAE & $=0.829$ & РИНЦ (Russia & $=0.156$ & PIF (India) & $=1.940$ \\
\hline & GIF (Australia) & $=0.564$ & ESJI (KZ) & $=8.716$ & IBI (India) & $=4.260$ \\
\hline & JIF & $=1.500$ & SJIF (Morocco & $=5.667$ & OAJI (USA) & $=0.350$ \\
\hline
\end{tabular}

Вот здесь-то и возникает и обостряется реальная потребность в системном подходе, а не просто в его декларации. В практической деятельности в самой постановке проблемы, в раскрытии ее содержания мы нередко исключаем саму возможность системного подхода к решению проблем.

Не следует думать, что качество определяется только технологическими составляющими, есть факторы, которые выходят за пределы технологии. Это факторы культуры труда, эстетики производства, состояния рынка, общественного сознания, инфраструктуры производства.

Системный подход в методологическом отношении предполагает учитывать не только то, что существует в наличии, в данной продукции, в готовом виде, но и то, что существовало в процессе ее изготовлении или формирования. Во многих случаях это были сложные и длительные процессы, в которых что-то исчезает, превращается в нечто иное, что-то меняет статус. Но ничто не проходит бесследно, и все остается в той или иной мере в качестве. Тем и ценно само понятие качества, что оно ориентирует на системный подход, если рассматривается как цель управления, что оно требует учитывать факторы процессуальности и структуры, существования и развития, факторы соответствия определенной внешней среде, интересам человека, ценностям общественной жизни. Сегодня для управления качеством необходимы не только стандарты и государственные требования к качеству. Они могут отражать лишь минимальный уровень качества, которое должно защищать государство. Вообще государственные требования к качеству — это система административного управления качеством. Никакие стандарты и государственные требования не смогут успевать за меняющимися интересами человека, рыночными процессами конкуренции, за изменением системы ценностей и образа жизни. А ведь именно они и определяют понимание качества и необходимость гибкого, социально-экономического управления качеством.

Качеству

отражающие экономических процессов. Качество должно определяться рыночными ситуациями, характеризующими процессы динамики спроса и предложения, потребностей и ценностей. Ведь только рынок посредством механизмов спроса и предложения, конкуренции, ценообразования и других процессов может показать истинное качество продукта, показать, что надо учитывать в его характеристиках. Государственные требования, если они должны быть, могут гарантировать лишь минимум качества, посредством которого строится система защиты потребителя от совершенно недоброкачественной продукции. Настоящая динамика качества может быть понята только по экономическим показателям спроса и потребления, конкуренции, цены, функционального назначения продукта, его влияния на образ жизни и роль в изменении образа жизни человека.

Качество - это не только совокупность свойств продукта, это и инициатива, и активность производителей в достижении этих свойств, в поиске и достижении их определенной комбинации.

Качество - это понятие социальноэкономического типа, это не статичная система свойств, это отношение человека к своему труду, к обществу, к управлению.

Качество - это тип развития, это новые подходы к регулированию циклов жизни продукции, созданию новых видов продукции, оценке морального старения и физического износа, учета принципа универсальности.

Управление качеством требует и соответствующей этой цели системы информационного обеспечения. Опираясь только на скудные данные отечественной отчетности, нельзя подчас составить истинную картину состояния качества, тем более найти причины его изменения или оценить процессы формирования. А ведь главное в управлении - это истоки качества и тенденции его изменения.

В традиционном представлении проблема управления качеством сводится главным образом к проблеме контроля качества. Это признак и фактор административного подхода к управлению качеством. Но опыт, как отечественный, так и зарубежный, показывает, что главным фактором управления качеством является комплексное мотивирование качества, при котором ведущую роль играет не контроль, он может быть сведен к минимуму, а образ деятельности производственного работника, в котором соединяются и функции, и цели, и средства самоутверждения, и интересы, и отношение к фирме, и коммуникабельность, и социально-экономическая атмосфера деятельности.

Управление должно быть ориентировано именно на образ деятельности, соответствующий определенному типу качества деятельности.

Это в итоге дает качество продукции и без жесткого контроля административного типа, а контроля как системы аналитической оценки.

В рыночной экономике «знак качества» это цена продукции, её известность, спрос, имидж предприятия, которое недоброкачественную продукцию вообще выпускать не может. Достижение определенного качества требует затрат. Величина затрат на 


\begin{tabular}{|c|c|c|c|c|c|c|}
\hline \multirow{4}{*}{ Impact Factor: } & ISRA (India) & $=3.117$ & SIS (USA) & $=0.912$ & ICV (Poland) & $=6.630$ \\
\hline & ISI (Dubai, UAE & $=0.829$ & РИНЦ (Russia & $=0.156$ & PIF (India) & $=1.940$ \\
\hline & GIF (Australia) & $=0.564$ & ESJI (KZ) & $=8.716$ & IBI (India) & $=4.260$ \\
\hline & JIF & $=1.500$ & SJIF (Morocco & $=5.667$ & OAJI (USA) & $=0.350$ \\
\hline
\end{tabular}

качество - важнейшая характеристика, отражающая управление качеством. Но затраты на качество еще не характеризуют потенциал достижения качества. Могут быть затраты очень высокими, но качество низким, потому что затраты не всегда имеют непосредственную и прямую отдачу. Они иногда служат лишь последовательному формированию потенциала качества, например, затраты на квалификацию работников, инфраструктуру производства.

Поэтому в управлении качеством большое значение имеет формирование потенциала качества, который включает культуру деятельности, социально-психологическую атмосферу, квалификацию и образование работников, технологию, техническую вооруженность, тип организации деятельности.

Качество действительно предполагает серьезные затраты, но оно гарантирует устойчивую рыночную позицию. Работая на качество, производитель создает уверенность в своем и национальном будущем. Правильно выстроенное понимание качества гарантирует перспективу даже в условиях отечественного полу-рынка. (рисунки 3 и 4) [25]

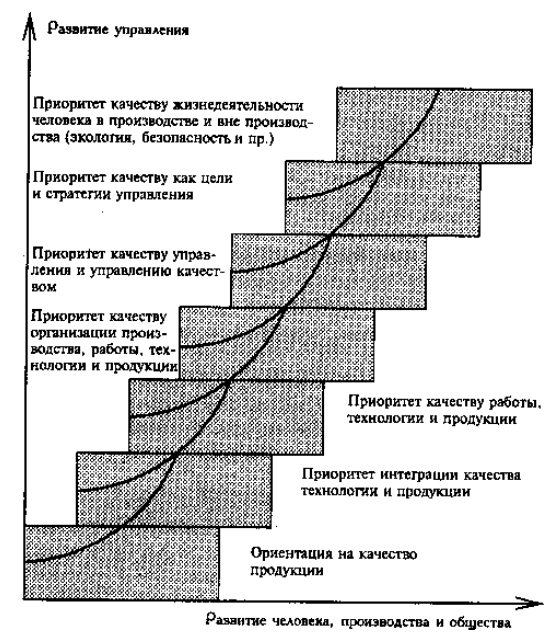

Рисунок 3 - Изменение приоритетов и роли управления в достижении качества, семь шагов в будущее
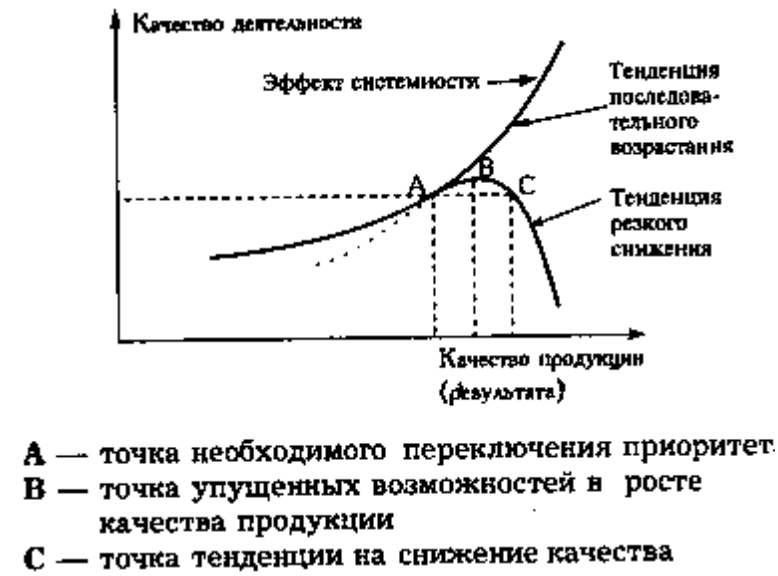

Рисунок 4 - Качество деятельности и качество продукции.

Обозначим новые подходы к управлению качеством.[24]

1. Качество должно войти в процесс управления как цель, определяющая все необходимые средства ее достижения. Разница в том, что цель направляет развитие, а средства обеспечивают целенаправленность процессов, возможность достижения цели. Качество - это то, к чему надо стремиться, а не то, что выступало бы инструментом или методом какихлибо достижений иного характера.

2. От ориентации на качество продукции надо переходить к ориентации на качество деятельности. Это требует расширить круг 


\begin{tabular}{|c|c|c|c|c|c|c|}
\hline \multirow{4}{*}{ Impact Factor: } & ISRA (India) & $=3.117$ & SIS (USA) & $=0.912$ & ICV (Poland) & $=6.630$ \\
\hline & ISI (Dubai, UAE & $=0.829$ & РИНЦ (Russia & $=0.156$ & PIF (India) & $=1.940$ \\
\hline & GIF (Australia) & $=0.564$ & ESJI (KZ) & $=8.716$ & IBI (India) & $=4.260$ \\
\hline & JIF & $=1.500$ & SJIF (Morocco & $=5.667$ & OAJI (USA) & $=0.350$ \\
\hline
\end{tabular}

факторов, включаемых в методологию анализа проблем, их постановки и поиска. Это означает понимание того, что качество продукции определяется качеством жизни, именно оно показывает, какое качество необходимо, достижимо; это означает, что качество продукции надо рассматривать в ракурсе качества жизни. Это свидетельствовало бы о подлинно человеческом факторе управления. [25]

3. Управление качеством должно опираться на рыночные механизмы экономического развития. Это означает, что не следует стремиться управлять качеством на основе требований. Главное - это экономическое мотивирование качества, как в целом, так и в мелочах, обеспечение его достижения, исследование качества.

4. Методология управления качеством предполагает системный подход. Это означает, что в управлении качеством главным становится выявление всех скрытых и явных, прямых и опосредованных связанных факторов, влияющих на качество и формирующих качество. Назовём практические рекомендации по управлению качеством:

1. В работе с персоналом надо уделять внимание не только его квалификации, но и качеству образования.

2. Не стремиться предъявлять требования к качеству продукции или даже к качеству работы, но стремиться повысить активность по отношению к качеству, искать пути улучшения качества на каждом рабочем месте, формирования качества, как в мелочах, так и в целом.

3. Необходимо найти главное в процессе формирования качества деятельности. Оно различно для различных фирм, но оно всегда существует

4. Не стандарты и требования решают проблему качества, а люди, заинтересованные в повышении качества.

5. Стремиться к качеству деятельности - это значит не только хорошо работать, а стремиться к самосовершенствованию, творчеству, самообразованию.

Качественность деятельности, с одной стороны, показатель качества жизни человека (так должно быть!), с другой - качественная деятельность встраивается в качество того, что он преобразует. Качество «первой» (естественной) природы формируется само по себе как совокупность объективно связанных естественных признаков, стихийно. Качество «второй» (реконструированной, приспособленной человеком под свои интересы) природы синтетическое. Таким образом, качество можно представить в виде двойной спирали, образуемой естественными признаками природного материала (возможно - в отношениях людей, знаниях, выраженных опосредованно) и качественными характеристиками человеческой деятельности - знаниями, эмоциями, волей, ценностной ориентацией, мастерством. В итоге качество продукта в отличие от самого продукта воплощает качество личности.

\section{References:}

1. Aleshin, B. S., et al. (2004). Philosophy and social aspects of quality. Moscow: Logos.

2. Porter, M. (2002). Competition: translation from English. (p.496). Moscow: Publishing house "Williams".

3. Minin, B. A. (1989). quality Level. (p.182). Moscow: Publishing house of standards.

4. (2012). Technical regulation " on safety of light industry products "[electronic resource] Retrieved March 07, 2012, from http://www.tsouz.ru.html

5. (2012). Technical regulation "on the safety of products intended for children and adolescents" [electronic resource] Retrieved March 07, 2012, from http://www.tsouz.ru.html
6. Rebrin, Y. I. (2004). quality Management: textbook. (p.174). Taganrog: Publishing house TSURE.

7. (2001). Performance and quality management. Modular program: Per. with English. In ed. by I. Prokopenko and K. North (Eds.). in 2 hours Part 1. (p.800). Moscow: Case.

8. (2011). GOST ISO 9000-2011. Quality management system. Basic provisions and dictionary [electronic resource] Retrieved 2019, from http://protect.gost.ru/

9. (2015). GOST ISO 9001-2015. Quality management system. Requirements [electronic resource] Retrieved 2019, from http://protect.gost.ru/

10. Feigenbaum, A. (2006). quality Control. (p.471). Moscow: Economics. 


\begin{tabular}{|c|c|c|c|c|c|c|}
\hline \multirow{4}{*}{ Impact Factor: } & ISRA (India) & $=3.117$ & SIS (USA) & $=0.912$ & ICV (Poland) & $=6.630$ \\
\hline & ISI (Dubai, UAE & $=0.829$ & РИНЦ (Russia) & $=0.156$ & PIF (India) & $=1.940$ \\
\hline & GIF (Australia) & $=0.564$ & ESJI (KZ) & $=8.716$ & IBI (India) & $=4.260$ \\
\hline & JIF & $=1.500$ & SJIF (Morocco) & $=5.667$ & OAJI (USA) & $=0.350$ \\
\hline
\end{tabular}

11. Salimova, T. A. (2005). History of quality management. (p.256). Moscow: KnoRus.

12. Buzov was a, B. A. (2006). quality Control of products. Technical regulation, standardization and certification: textbook. the allowance for high schools. (p.176). Moscow: Academy.

13. Ponomarev, S. V., Mishchenko, S. V., \& Belobragin, V. Y. (2012). product quality Management. Introduction to quality management system. (p.332). Moscow: RIA "Standards and quality".

14. Prokhorov, V. T., Mishin, Y., \& Stepanov, B. F. (2005). the Ideology of quality - the development perspective. Technical regulations - a basic component of quality management services and products: international collection of scientific works/ Orgues. Mine: publishing house of urgues.

15. Boytsov, V. V., Kuznetsova, M. V., \& Elkin, G. I. (2007). the Concept of quality of life: textbook. (p.236). Moscow: Academy of quality problems.

16. Zhikharev, A. P. (2005). Grafoanalitichesky method of assessing the quality of the material of shoes. Technical regulation of the basic component of quality management of services and products: international. collection of proceedings. Mine: publishing house of urgues.

17. Osicka, N. I., Prokhorov, V. T., \& Katkov, E. I. (2008). Stability of enterprises guarantee the quality of their shoes. Technical regulation: the underlying basis of the quality of goods and services: international collection of scientific works. works / Orgues. Mine: publishing house of urgues.
18. Imai, Masaaki (2005). Gemba Kaizen a Way to reduce costs and improve quality. TRANS. with English. (p.346). Moscow: Alpina Business Books.

19. Porter, M. (2005). Competition. Per. with English. (p.608). Moscow: Ed. house "Williams".

20. Pande, P., \& Kholp. (2004). "What is ' Six Sigma'? Revolutionary method". TRANS. with English. (p.158). Moscow: OK Mountaineering. - Business Books.

21. Womak, J. P., \& Jones, D. T. (2005). Lean manufacturing: How to eliminate losses and to achieve prosperity of your company [Text]. lane.from English. - 2nd ed. (p.473). Moscow: Alpina Business Books.

22. George, L. M. (2005). Lean manufacturing + six Sigma: combining the quality of six Sigma with the speed of lean manufacturing [Text]. TRANS. (p.360). Moscow: Alpina Business books.

23. Shingo, S. (2006). Quick changeover: the revolutionary technology of optimization of production [Text]. (p.344). Moscow: Alpina Business Books.

24. Vader, M. (2005). lean production Tools: MiNi-guide to the implementation of lean production techniques [Text]. lane.from English. (p.125). Moscow: Alpina Business Books.

25. Imai, Masaaki (2005). Gemba Kaizen the Way to reduce costs and improve quality [Text] / TRANS. from English. (p.346). Moscow: alPina Business books. 